University of Louisville

ThinkIR: The University of Louisville's Institutional Repository

1941

\title{
A study of the George W. Morris School and community with emphasis upon the personnel work of the school.
}

Naomi Peak

University of Louisville

Follow this and additional works at: https://ir.library.louisville.edu/etd

Part of the Education Commons

\section{Recommended Citation}

Peak, Naomi, "A study of the George W. Morris School and community with emphasis upon the personnel work of the school." (1941). Electronic Theses and Dissertations. Paper 1848.

https://doi.org/10.18297/etd/1848

This Master's Thesis is brought to you for free and open access by ThinkIR: The University of Louisville's Institutional Repository. It has been accepted for inclusion in Electronic Theses and Dissertations by an authorized administrator of ThinkIR: The University of Louisville's Institutional Repository. This title appears here courtesy of the author, who has retained all other copyrights. For more information, please contact thinkir@louisville.edu. 
UNIVERSITY OF LOUISVILLE

A STUDY OF THE GEORGE W. MORRIS SCHOOL AND COMMUNITY WITH EMPHASIS UPON THE PERSONNEL WORK OF THE SCHOOL

\author{
A Dissertation \\ Submitted to the Faculty \\ Of the Graduate Sohool of the University of Louisville \\ In Partial Fulfillment of the \\ Requirements for the Degree \\ of Mester of Arts
}

Department of Education

By

Naomi Peak

Year

1941 
NAME OF STUDENT: NAOMI PEAK

TITLE OF THESIS : A STUDY OF THE GEORGE W. MORRIS

SCHOOL AND COMMUNITY WITH EMPHASIS

UPON THE PERSONNEL NORK OF THE

SCHOOL

APPROVED BY READING COMITTEE COMPOSED OF THE

FOLIOWING MEMBERS:

NAME OF DIRECTOR:

DATE: June, 1941 
TABLE OF CONTENTS 
PART I

A SOCIO-ECONOMIC STUDY OF THE COMMUNTTY IN WHICH THE GEORGE W. MORRIS SCHOOL IS IOCA TED

I. The Geographical Setting of the George W. Morris School Distriot.......................... 6

II. The Physical Deterioration and Social Changes of the George W. Morris Sohool District........... 10

III. A Population Study of the George 7 . Morris School District.............................. 20

IV. Some Factors Affecting Famfly Life in the George W. Morris School District................. 36

\section{PART II}

THE GEORGE W. MORRIS SCHOOL

I. The George W. Morris School Building............. 64

II. The School staff of the George $r$. Morris School.... 69

III. The George W. Morris School Enrollment............ 78

IV. The Educational status of the Pup1ls............. 91 
PART III

THE PIRSONNEL TORK OF THE GEORGE . MORRIS SCHOOL

I. Who Does the Personnel Work at the George W. Morris School.

II. The Work of the Visiting Peacher in the George $W$.

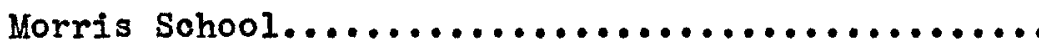

III. A Discussion of the Problems which the Children of the George W. Morris School Present to the School,

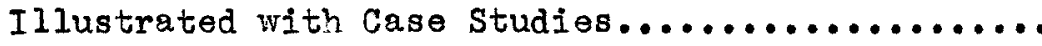


IIST OF TABLES 


\section{IIST OF TABLES}

TAB LE

PACE

I. Totel Population and Donsity of Population in

Census Tracts 48, 57, 58, and 59 in 1938

II. Age Distribution of Population in Census

Tracts $48,57,58$, and 59 in 1938

III. Dwelling Units by Ownershlp and Tenancy in Census

Traots 48, 57, 58, and 59 in 1938

IV. Population in Orner-Occupled and Rental Drelling

Onits in Consus Tracts $48,57,58$, and 59

In $1938 \ldots \ldots \ldots \ldots \ldots \ldots \ldots \ldots \ldots \ldots \ldots \ldots \ldots \ldots \ldots \ldots \ldots \ldots$

V. Number of Jurenile Delinquents in the Juvenile Court

by Race and Sex in the City of Louisville

in 1935

VI. Number of Jurenile Delinquents Before the Jurenilo

Court in Census Traots 48,57,58, and 59

in $1935 \ldots \ldots \ldots \ldots \ldots \ldots \ldots \ldots \ldots \ldots \ldots \ldots \ldots \ldots \ldots \ldots \ldots$

VII. Jurentle Delinquency Compared with Major and Minor

Crimes by Census Tracts $48,57,58$, and 59

In 1935

VIII. Rank of Census Tracts 48,57,58, and 59 in Magnitude of Delinquency with the Eighty Census Tracts of the City in 1935 
IX. Rank of Census Tracts 48,57,58, and 59 in Magnitude of Delinquency of Major Crimes and of Minor Crimes with the Eighty Census

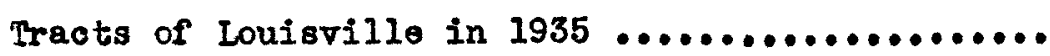

X. The Economic Status of the 394 Families Represented in the George N. Morris School During the School Year 1938-1939, Showing Whether the Mother, Father or Both Were Employed, the Number of Families on Relief and the Number of Families Having No Employment and also Showing the Number of Children in Each Classification

XI. An Analysis of the 206 Families Represented in the George W. Morris School where Both or One Parent had Full Time Private Employment Showing the Number Who Lired on at Least a Mintmum Standard Budget, and the Number Who Lived on Less Than a Minimum Standard Budget and also Showing the Number of Children in Each Classifioation

III. An Analysis of the Type of Support of the 54 Families Represented in the George W. Kosels Sohool in the Onemployed Group Showing the Number of Children in Each Classification 
XIII. An Analysis of the Broken 'Homes in the 394 Homes Represented in the George T. Morris School Showing the Cause, the Number of Homes Broken and the Number of Ohildren Affected

XIV. The Number of Families and the Number of Children

In the George W. Morris School in Which the Mother was Gainfully Enployed Showing the Status of the Father and Giving an Analysis of How Much Planned Care the Children Recoived While the Mother was Out of the Home

XV. The Number of Families Represented in the George $W$. Morris School District Known to Social Agencies Showing the Number of Families in Which Agencies were Active During the School Year 1938-1939, the Number of Families Known to Agencies Prior to that Year and the Number of Families on Which the Agencies Only Cleared

XVI. The Number of Families Represented in the George W. Morris Sohool Known to One or Hore Social Agenoies ... 59 IVII. The Type Drelling in thich the Famflies Represented In the George W. Morris School Ifived, Showing the Number of Families and the Number of Children Who Ifred in Each Type ..........................61 
XVIII. The Educational Training and Teaching Experience of the Principal and Teachers of the George W. Morris Sohool

XIX. The Number of Forelgn Born and the Number of Children of Foreign Born Parents or Grandparents In the George W. Morris School During the School Yoar 1938-1939 80

Ix. The Countries from which the Parents or Grandparents of the Children of Foreign Descent in the George W. Morris School Came, Showing the Number of Families and the Number of Children ............

XXI. Length of Time the 580 children Fnrolled in the George W. Morris School During the School Year 1938-1939 Have Been in Attendance at This School ..

XXII. The Number of Years the Children of the 6A Grades of February 1939 and of June 1939 Attended the George W. Morris Sohool 85

XXIII. The New Entries at the George W. Morris School for the School Year 1933-1934, Showing from where They Came and the Number Who Returned to the School During the Two Following Years 
XXIV. Age Grade Distribution March 15, 1939, Showing the Per Cent of Pupils of the George W. Morris School Who Wore Underage, Normal Age and Overage Compared With the Per Cent of Pupils in the White Elementary Schools of the Louisville Public School System Underage, Normal Age and Orerage $\ldots \ldots \ldots \ldots \ldots \ldots \ldots \ldots \ldots \ldots \ldots \ldots \ldots \ldots \ldots \ldots \ldots \ldots \ldots$

XXV. Grade Progress Study Maroh, 15, 1939, Showing a Comparison of the Distribution of the Pupils of the George W. Morris School With the Pupils of the Wite Elementary Schools of the Louigville Public Sohool System tho Showed Normal Progress and Deviation from Normal Progress 96

XXVI. Medians for Chronological and Mentel Ages, Reading, Language Usage, Arithmetic Reasoning and Computation Grade 6A, for the George W. Morris Sohool Compared with the Standard Medians and with the Medians for the 6A Grades of the Public Sohools

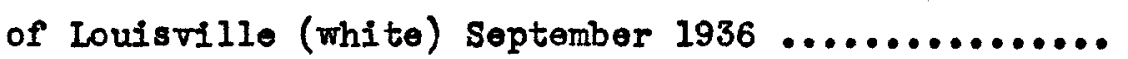

XXVII. Medians for Chronological and Mental Ages, Reading, Language Usage, Arithmetio Reasoning and Computation Grade 6A, for the George W. Morris School Compared with the Standard Medians and the Medians for the 6A Grades of the Publio Schools of Louisville (white) February 1937 
XXVIII. Medians for Chronological and Mental Ages, Reading, Language Usage, Arithmetic Reasoning and Computation Grade 6A for the George W. Morris School Compared with the Standard Medians for the 6A Grades of the Public Schools of Louisvillo (white) september, 1937 ............................ 100

XXIX. Medians for Chronological and Mental Ages, Reading, Language Usage, Arithmetic Reasoning, and Computation Grade 6A for the George W. Morris School Compared with the Standard Medians and with the Medians for the $6 \mathrm{~A}$ Grades of the Public Schools of Louisvillo (white) February, 1938 101

XXX. Number of Cases Referred to the Visiting Teacher at the George W. Morris Sohool as Compared with the Number of Cases Referred to the Visiting Teachers in the Louisville Public Sohool System (white) for the School Year 1938-1939 
LIST OF MAPS AND GRAPHS 
IIST OF MAPS AND GRAPHS

FIGURE

PAGE

I. Map of Louisvilie, Kentuoky Showing the Iocation of the George W. Morris School Distriot.......... 7

II. Map of the George W. Morris School District Showing Three Types of the Living Quarters, the Religious and Social Institutions, the Agencies for Social Welfare and the Places Contributing Toward Social Deterioration.

IIX. Map of the George W. Morris School District Showing the Relationship of the School District to Census Tracts $48,57,58,59 \ldots \ldots \ldots \ldots \ldots \ldots \ldots \ldots \ldots \ldots \ldots \ldots$

IV. Per Cent of Absence by Causes of the liorris School as Compared with the Louisville Public School System for the School Year 1938-1939.

V. Per Cent of Absence by Month of the Loufsvilie Public School System (white) and of the George W. Morris School for the School Year 1938-1939.... 127 
A STUDY OF THE GEORGE W. MORRIS SCHOOL AND COMMUNITY WITH EMPHASIS UPON THE PERSONNEL WORK OF THE SCHOOL 
INTRODUC TION 


\section{INTRODUCTION}

Any school, it makes no difference in what locality it may be located, has personnel problems with which to deal. However, the personnel problems of any given school are, in a measure, the reflection of the life of the community in which that particular sohool is located. The problem may be the same in any school but to some extent, at least, the contributing factors differ as the community differs. Shaw says the following concerning this point of view:

Behavior can be studied profitably in terms of the situation out of which it arises. In other words, behavior responses can be thought of as functions of situations. Analysis of individual factors is indispensible, but until the situations in which the indiridual's behavior has ocourred are studied and analysed, an understanding of his behavior must necessarily remain incomplete.

The point is that from the soclological point of view, behavior of persons becomes intelligible when studied in terms of the social situation in which it has ocourred. 1

Therefore, every school should have a knowledge as well as an understanding of and an insight into the life of the community which it serves, in order to be better equipped to handle the problems which the children of that community present.

However, the child's environment consists not only of the community from which he comes but it also consists of the environment of the school which he attends. This sohool environment is made up, in part, of the kind of school bullding, of the training and experience

\footnotetext{
I Shaw, Clifford R., Delinquency Areas, pp 1-10.
} 
of the school staff, of the attitude of the school staff toward the handling of the personnel problems, of the personnel of the school population and of the educational status of the pupils.

In addition to the knowledge of the community and of the school in handling personnel problems, it is necessary to know as much about the individual ohild who is presenting the problem as is possible. It is necessary to know about his heredity, his physical and mental ability, his home life, his attitudes and wishes, his interpretation of the situation and his conception of himself. Kilpatrick terms this the "total situation". He expresses his viow point in the following quotation:

As we look more closely at life itself, the newer biologio view of organism helps us to understand behavior as possibly never beforo. Any organism is seen as a self-regulative pattern, inextricably interwoven with the environment. When by a change oither within or without the organism the equilibrium of the organism is upset, there ensues a strain which wo varlously call need, want, wish, drive, preference or the like. Consequent upon this strain there ensue movements directed towrard the environment which tend to restore the lost equilibrium . . . . Any organic activity is as much the affair of the environment as it is of the organism. Any hablt of the ohild belongs as truly to the situation as to the child, for it joins both together. And the situation is the actual total situation in all its partioular manifestations to which the child is in fact sensitive... . The whole child with all its offectual past now actually located in a present concrete situation with all its effectual connectedness--this is the only unit.l

Thus, the purpose of this thesis is threefold: First, to present a socio-eoonomic study of the community in which the

1 Kilpatriok. A Reconstructed Theory of the Educative Process, pp 3-7. 
George $\pi$. Morris Sohool in Louisville, Kentucky is situated; second, to present a study of the various phases of the school; and third, to discuss and to illustrate by means of case studies some of the problems the children coming from this community present to the school and also to illustrate how through a knowledge of the district, through a recognition of the strengths and inadequacies of the school and through as complete a study of the individual child, as possible, some of these problems are treated.

To present this, the thesis is divided into an introduction, three divisions and a conclusion. Each division is divided into chapters and each chapter is devoted to a particular phase of the problem. The first division, of four ohapters, is a socio-economic study of the neighborhood. It gives the location and description of the neighborhood; the physical deterioration and social changes of the neighborhood; a type of population study, as well as, a study of the rate of delinquency of the community; and a study of some of the factors affecting the family life of the children of this neighborhood. The socond dirision, of four chapters, deals with the school itself. Sehool, in this sense, includes not only the building but various phases of the school. These phases are the physioal aspects of the building; the educational training, the teaching experience as well as the attitude of the staff toward the work of the sohool; an analysis of the school onrollment; and the educational status of the children as compared with the status of the children of the other 
white elementary sohools in the Iouisville Public School System, The third part, of three chapters, deals with the personnel work done in the school. This part tells by whom the personnel work is done; discusses the philosophy on which the personnel work is besed; tells of the contact the school has with the social agencies and through a disoussion of the problems which the children of this community present to the school, illustrated by case studies, demonstrates how the school endeavored to meet and solve the problems of the individual children.

The material for this thesis was gathered in the following ways; through interviews with residents of the neighborhood; from a population study made in 1938 by Dr. Robert Irutak, of the University of Louisville, under the auspices of Chrlst Church Cathedral; from a study of the rate of delinquency by census tracts in Iouisville, Kentucky, nade in 1935 as a Works Progress Administration projeot; by a home visit made to every family represented in the school for the school year 1938-1939, in order to obtain the information for the study dealing with some of the factors affecting the family life of the children of this district; through interviews with church and social workers; through information obtained from the Social Service Bxchange, a clearing house for social agencies; through minutes of the Board of Education of the Louisville Public School System; through records from the Attendance and Census Departments and the Bureau of Research of the Louisville Public School System; through reports of 
the Louisville Board of Health; through records and case studies of the children who attended the George W. Morris School; through newspaper reports; through the attendance laws of the state of Kentucky; and through various books and pamphlets. The visiting teacher at the time this thesis was written had worked in this school four years as the Kindergarten teacher and twelve years as the visiting teacher, so throughout the thesis are interpretations of how she has developed an understanding of and an appreciation for the need of personnel work. The case studies are all cases which she handled. Her intimate knowledge of the distriet and of many of the families, her being a familiar part of the school and neighborhood onabled her to get the information for the study dealing with some of the factors affecting the family life from the families without any difficulty.

And so, to summarize, the purpose of this thesis is to present a socio-economic study of the community in which the George T. Morris School is located; to present a study of the various phases of the school; and to demonstrate, through a discussion of the problems the children presented to the school, 1llustrated with oase studies, how some of these problems were treated. 
CHAPTER I

THE GEOGRAPHICAL SETTING OF THE GEORGE W. MORRIS SCHOOL DISTRICT 


\section{CHAPTER I}

THE GEOGRAPHICAI SETTING OF THE

GEORGE W. MORRIS SCHOOL DISTRICT

Since the purpose of this thesis is in part to present a socio-economic study of the community in which the George $\pi$. Morris School in Louisville, Kentucky is located, the location and description of this community should be the first consideration. Louisville, Which is located at the Falls of the Ohio River, has, by the 1940 consus, a population of $319,077^{1}$ inhabitants and covers an area of approximately forty square miles. 2 The Morris school distriot lies east of the contral business distriot of the city and covers an area of fifty-three eity blooks.

The boundary lines for the Morris School are as follows:

Northern: Ohio River.

Bastern: Preston Street, Hancock and Jackson Streot. Preston from the River (including Preston) south to Walnut, then east (including Walnut) to Hancock, then south (not including Hancock) to Jacob.

Southern: Jacob Street and Broadway. From the intersection of Jackson and Jacob west (Including Jacob) to Floyd, then north (not including Floyd) to Broadway, then west (not including Broadway) to Third.

\footnotetext{
1 U.S. Census, 1940

2 Real Property Survey and Low Income Housing Survey, Vol. I, p. 16, 1939 .
} 


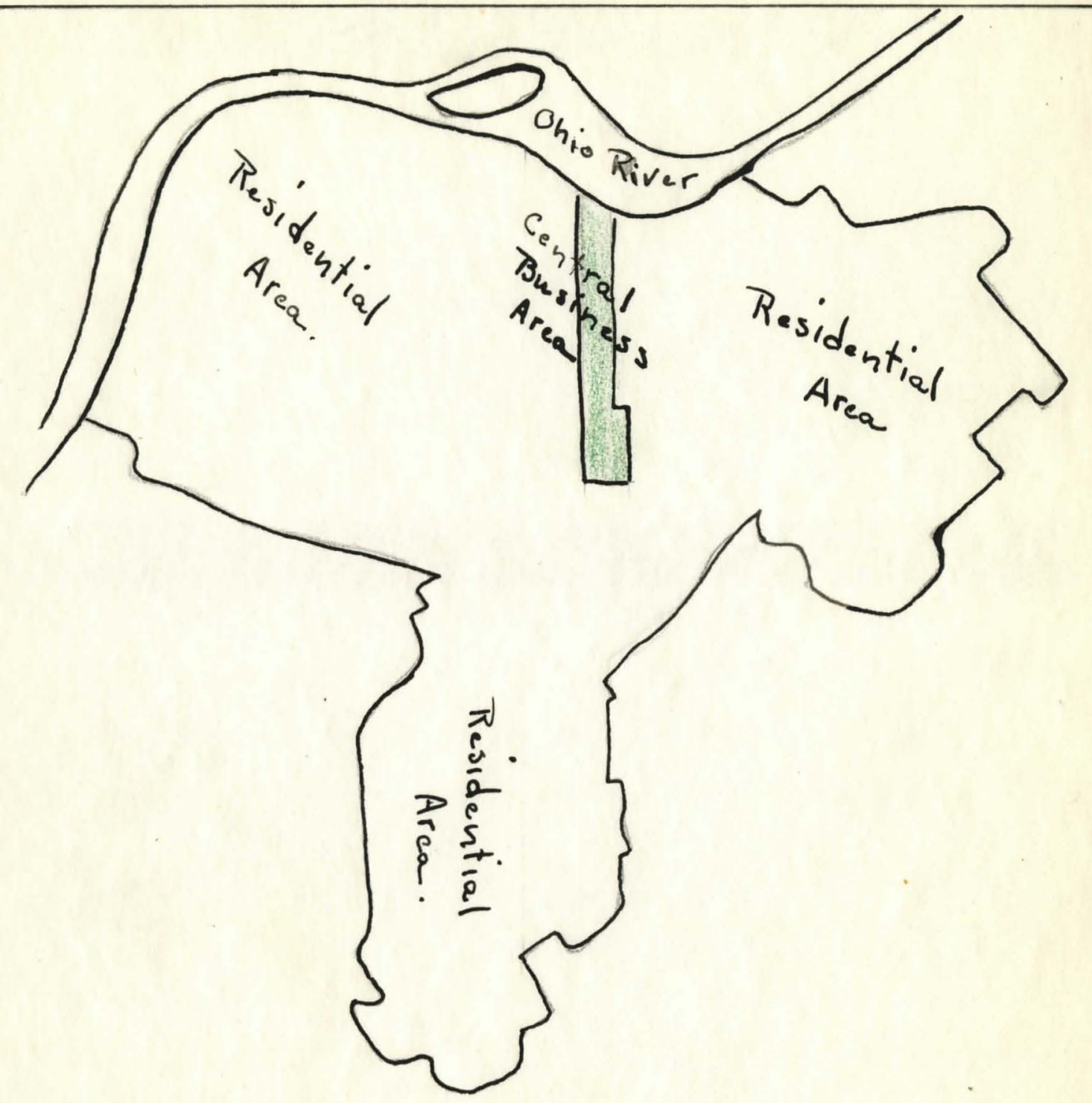

MAP OF IOUISVILLE, KENTUCKY

SHOWING THE LOCATION OF THE

GEORGE W. MORRIS SCHOOL DISTRICT

Legend

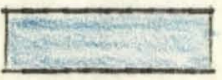

George W. Morris School District 
Western: Third Street.

From the intersection of Third and Broadway north (not including Third) to the River. 3

The school district is bounded on the north by the Ohio River and on the east by a slum or semi-slum area of tenements, of houses that have been converted into two or three family dwellings and rooming houses. The government slum clearance project which has resulied in the building of a group of low rent apartment buildings for white poople is located in this area, just on the border line of the Morris School district. The school district is bounded on the south by an old residential section which is fast becoming a rooming house area and on the west the district is bounded by the central business area of the city.

Beginning at the northern end of the district and coming south, there is first the Ohio River front. On this front is a portion of the municipal dock, a sand company, ware houses and a rajlroad yard. Then comes a section of ware houses, wholesale houses and produce houses. An outdoor market where farmers sell their produce is situated in this section and covers a city block. In this section, particularly on the eastern edge, are all kinds of small shops, second hand stores, restaurants, pool rooms and saloons. The second and third floors of many of these buildings are used for dwelling places. Following this is an area of old houses that have

\footnotetext{
${ }^{3}$ Record of School District Lines, Superintendent's office, Board of Education, Louisville Public Bthool System, 1938.
} 
been converted into two and three family dwellings and rooming houses. In this section are two large apartment hou ses which are in reality little less than rooming houses. Hore, 2180 is an old residence owned by a seminary for religious training. This residence has been converted into apartments for the use of the seminary students and their families. In this southern section of the district is a medical school, a school of dentistry and pharmacy, two hospitals, a clinic for tuberculosis and a seminary for religious training. In the school district there is also a Hebrew sohool, an elementary school for colored ohildren, a senior trade school, seven churches, one synagogue and besides the hospital and olinfc eleven agencies for social welfare. In all of the district there are only a few single dwelling houses. In all sections of the distriot houses have been torn down and the property converted into paring lots. And so, it is in this district composed of business houses, of rooming houses, of old residences converted into two or three family dwollings, a district contalning sources which contribute toward disorganization and deterioration of family life that the pupils of the George W. Morris School live. 


\section{CHAPTER II}

THE PHYSICAL DETERIORATION AND SOCIAL CHANGES OF THE GEORGE T. MORRIS SCHOOL DISTRICT 
CHAPTER II

THE PHYSICAL DETERIORATION AND SOCIAL CHANGES OF THE GEORGE W. MORRIS SCHOOL DISTRICT

The size of a given community and its location with relation to the rest of the oity is an important part of any study. of equal importance is a knowledge of the physical and social aspects of a comnunity both present and past because any community is affected by the influences of the past as well as of the present. Therefore, a short description of the physioal deterioration and social changes which have and are talding place in the George W. Morris Sohool distriot is presented at this point.

The physical and social changes in the Morris School district are naturally the consequenee of the growth of the city. This neighborhood has gradually ohanged from a wealthy, oultural residential district to a slum or semi-slum district. The following quotation of Shaw's characterizes this district:

The zone in transition has been described as an interstitial area in the throes of change from residence to business and industry. Here a re to be found the slum or semi-slum districts of American cities where play is crime. Boys gangs, juvenile delinquency, poverty, desertion and bad housing abound.1

Thus, the physical and social conditions in communities within the city undergo marked changes which reflect the natural processes of city growth. Whereas in the outlying regions residential communities

I Shaw, Clifford R., Delinquency Areas, p. 19. 
grow up and become stabilized, those sections around the central

business district tend toward deterioration. Acoording to Burgess

this deterioration occurs in stages. He says concerning this:

In the decline of a neighborhood the following stages of deterioration have been marked out; first, the stage of residential home ownership, with a high degre日 of community spirit; second, the stage of tenancy with a decline of neighborhood loyalty; third, the invasion of business; fourth, rooming house stage; fifth entrance of a racial or nationality group of imputed inferior cultural status; sixth, the intrusion of vice and crime; seventh, the stage of social chaos; and eighth, the final stage, when business or industry takes full possession of the neighborhood. There are, of coursg, certain variations in this pattern, as when a residential area of single homes is transformed into an apartment house or residential hotel area.2

Although the deterioration in the Morris School neighborhood has neither followed these stages nor reached the final stage, it has in a large measure been the same.

Formerly this community was a wealthy cultural neighborhood of home ownership. The streets were lined with beautiful shade treos and contained handsome residences. There were no business houses on any of the streets except an occasional family grocery store. There was little or no sign of porerty. In the main, the population was made up of English, Irish and Scotch. 3

2 Burgess, E. W. The Natural Area as a Unit for Social Work in the Large City. Proceedings of the National Conference of Social Work, 1926, p. 509.

3 From an interview with Miss Johanna Wohmhoff, whose family moved to this neighborhood in 1850. Miss Wehmhoff still lives in the neighborhood. 
The revolutionary troubles in Europe during 1848-1849 caused a tide of German immigrants toward this country, distinct from that of previous periods, in that most of the immigrants were of the educated classes. 4 Cassaday estimated that about 1,800 of the population of Louisville in 1852 were Germans and that the number was being increased daily by new arrivals. 5 The fact that German was taught in all of the public schools of the city but in 1867 the teaching of it was limited to six schools and the George W. Morris School was one of the six, indicated that many German families settled in this neighborhood. 6

As early as 1854 business began to creep into the neighborhood. In this year Gustar Bittner opened his cabinet making shop on Brook Street, just north of Walnut Street.7 Also in June, 1854 , the Louisville and Frankfort Railroad Company bought from the Board of Education a piece of property on Jefferson Street between Floyd and Brook Streets for the railway station for their road which had just been completed. ${ }^{8}$ This purchase determined the future

4 Johnston, J. Stoddard--Memorial History of Louisville From Its First Settlement to the Year 1896 .

5 Cassady, Ben, The History of Louisville From Its Earliest Settlement Till the Year $185 \overline{2}, \mathrm{p} \cdot 24 \overline{6}$.

6 Minutes of the Board of Education, Public Schools of Louisville, July $6,1 \overline{867}$

7 The Louisville Courier-Journal, February 13, 1939.

8 Minutes of the Board of Education, Rublic Schools of Louisville, June $5,1 \overline{854}$ 
location of the wholesale produce district.9

Just after the Civil War foreigners other than Germans began to settle in the city. Firsi, came the Russian Jewr, 10 then a little later, the Italians. 11 These people settled on Brook, Floyd and Preston Streets between Market and Liberty Streets. At first they made their living by pedding their wares from the old oountry. Gradually they were able to build up small businesses in this section where they had settled. In the main these businesses were mercantile and produce, and today many of their descendents are carrying on the trades wich they started. About a decade later the Syrians began to move into the city and they, too, settled in this area. 12

As the city grew, as business crept into this area, as the foreigners increased, many of the original settlers of the neighborhood moved to other sections of the eity. Also, as the ohildren of the original families grew and married, they moved to newer sections of the city but many of the older generation remained.

\footnotetext{
9 From an Interviow with Mr. Charles Soholtz, President, Joo Denunzio Fruit Compeny, Louisville, Kentuoky

10 From an interview with Mr. Harry Russman, grandson of one of the first Russian immigrants to Louisvillo, and Mr. Morris Bass, one of the early Russian immigrants.
}

11 From an interview with Miss Frances Ingram, former head resident of the Neighborhood House.

12 From an Interview with Mrs. Mary Shaheon, widow of one of the first Syrian immigrants. 
Upon their deaths the houses were sold, some for rooming and boarding houses, some for businesses and others were given by the heirs to house various institutions. 13

At first these rooming and boarding houses were occupled by a very respectable, Industrious class of people but as more and more of the homes were converted into rooming hauses, the people living In them were of a much less fortunate element than formerly--people with low standards of living and morality, degenerates, drifters from other cities. Many of the former homes of the aristocrates are now nothing more than the most miserable tenements, and there is an ever-increasing lowering of the standards of living taking place.14 The follwing from the "Real Property Survey and Low Income Hou ding Survey of Louisville, Kentucky", for the year 1938-1939, gives an indication of the amount of conversion that has taken place in this district:

of the 2,309 single family siructures converted during the period of 1935 through 1938, thirty-four and three tenths per cent were completely converted while sixty-five and seven tenths per cent were partially converted. By partial conversion is meant either repairs or alteration to structures that may be returned to their original construction without large expenditures or money or time. Complete conversion means major structural changes which have so affected structures that they may not be restored to thelr former status without considerable expenditure.

13 From an interview with Miss Johanna Wohmhoff.

14 From an interview with Miss Johanna Wehmhoff. 


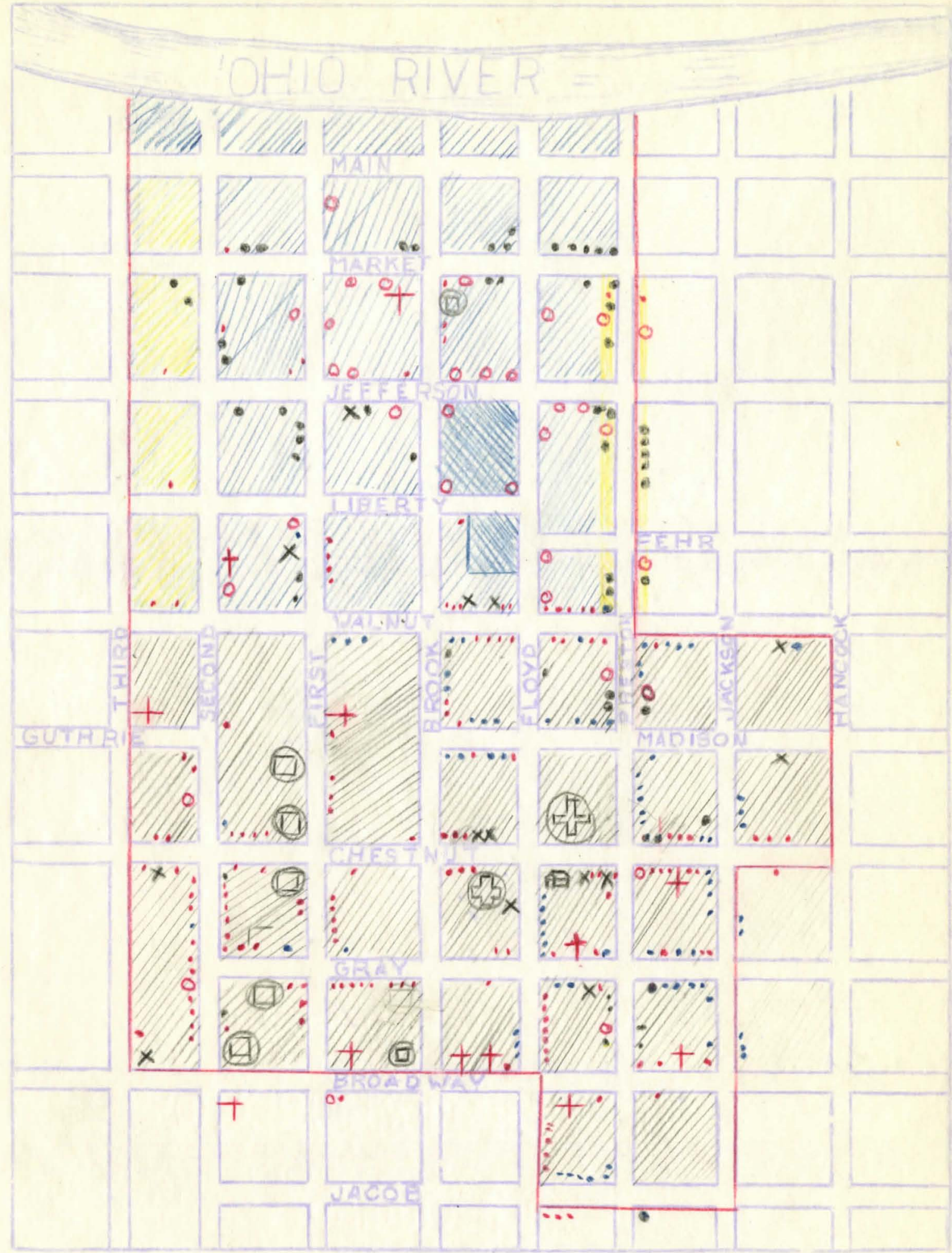

MAP OF THE GEORGE W. MORRIS SCHOOL DISTRICT SHOWING THREE TYPES OF THE LIVING QUARTERS, THE RELIGIOUS AND SOCIAL INSTITUTIONS, THE AG BNCIES FOR SOCIAL WELFARE AND THE PLACES CONTRIBUTING TOWARD SOCIAL DETERIORATION 


\section{LEG BEND}

- Boundary Lines of the George W. Morris School District

Warehouse, Produce and Wholesale Area

AII Area of Rooming Houses and Old Houses Converted into Two and Three Family Dwellings

D Area of Retail Business

Ward Farmers Outdoor Market

1 George W. Morris School

ET Hospitals

(1) Educational Institutions Other than the Morris School

$X$ Agencies of Social Welfare

† Churches and Synagogues

- Rooming Houses

- Houses Converted into Two and Three Family Dwellings

- Dwelling Places in Rear and on Second and Third Floors of Old Business Houses

Saloons, Cafes and Pool Rooms 
Although the conversion of residential structures was scattered over the entire city, the principal areas affected were the old residential districts lying east and west of the central business area. 15

The disintegration in the Morris Sohool neighborhood is shown not only in the fact that business has crept into the distriet and not only in the manner in which the people live, but it is also shown in the disorganizing influences which have gradually crept into the neighborhood. This area abounds in cheap restaurants, where alleged gambling and drinking take place; in saloons; and in alleged gambling houses and pool rooms. Although, to some extent, these are scattered throughout the neighborhood, they are more concentrated in the area between Market and Liberty Streets and Seoond and Preston Streets. Prostitution is also prevalent. Because of its clandestine nature, and because the city has no segregated area, it cannot be ascribed to any one part of the distriot. This section of the city Is also the center for the peddling of narcotics. At one time, in the area, from Main Street to Broadway and from Jackson to Fourteenth Street, there were seventy-five dope peddlers known to the police, 16

15 Real Property Survey and Iow Income Housing Area Survey of Louisville, Kentueky: $19 \overline{38-1939}$ 1:28-30

16 Loui svi lle Times, May 4, 1938. 
Another indioation of the deterioration is in the fact that the use of marihuana was introduced to the children in the neighborhood in a playground on the edge of the district. The Louisvilie

Courier-Journal for July 31, 1938 , printed the following:

The public playground at Jackson and Walnut enjoys the unpleasant distinction of being the scene of marihuana's introduction to Louisville youths. It was there that a cortain character known to police as Fedro began the city's sales and organization of the weod-smoking racket. 17

Bxcept for the playgrounds at the Neighborhood House, 18 the one at the school and the above mentioned one, there is no play space In the district for the children other than the streets and alleys. With one exception, the vacant lots are all parking lots. This exception is one small lot which is so overgrown with weeds and filled with rubbish that the children make no effort to play there. The river front affords no place for recreation. This is due probably to three things; first, the children are discouraged from playing here because of the danger; and second, the pollution of the river makes it a source of disease; and third, there are several squares devoted in the main to wholesale and produce houses between the river and the section of the district where most of the children Iive.

\footnotetext{
17 Louisville Courier-Journal, July 31, 1938.

18 Nelghborhood House, a Community Settlement.
} 
Thus, the Morris School district is one which retains some of Its earliest American people, some of the old German families, but whioh is largely populated by a less fortunate group of American families plus a small number of foreign families, Russians, Italians and Syrians. It is also a neighborhood where community influences contribute largely to the disintegration and disorganization of home life; a neighborhood that atracts families, who, because of some family problem, have already begun to be disorganized. It is from this district that the Norris School draws its children.

It may be expected that such a district presents to the school problems arising from low family incomes, such as lack of adequate olothing for the children or of the children coming to school with little breakfast and no money for lunch; problems of pupil accounting which arise in a conjested and shifting population; problems of the spread of contagion; problems of delinquency or of child neglect; problems of scholarship and of behavior of all types. How some of these problens are treated will be shown later in this thesis. 


\section{CHAPTER III}

A POPULATION STUDY OF THE

GEORGE W. MORRIS SCHOOL DISTRICT 


\section{A POPULATION STUDY OF THE}

GEORGE W. MORRIS SCHOOL DISTRICT

The two preceding chapters have given first, the geographical setting of the George W. Morris School neighborhood and second, a description of the social and physical changes which have taken place in the neighborhood. This chapter will present a type of population study of the district, showing the density of the population, the age distribution of the population, and the dwelling units by ownership and tenancy. The chapter will also present a study showing the rate of jurenile delinquency and major and minor orimes of this district as compared with the rest of the city. It is from such statistics as these that conclusions concerning the congestion of the district, the number of children in the district, the mobility of the population and the rate of delinquency can be made. It is the knowledge and interpretation of such material that should help the school realize the nature and extent of its problems and should help it in planning its program for meeting these problems.

Christ Church Cathedral, an Episcopal Church, located in the George W. Morris School district, several years ago initiated a project to study the community surrounding the Cathedral. The purpose of this project was to give the church information concerning the comunity, in order that the church might plan its work to fit the commity needs. The areas under study were census tracts 48 , 
58 and 59. Census tract 57 borders a portion of the school distriet and in the course of the year many of the children move into this area and continue to attend the Morris Sohool. So census tract 57 is included in the study. Therefore, the population study of the George W. Morris School neighborhood is a study of these four census tracts. The material for this is taken from the population study made by Christ Church Cathedral under the supervision of Dr. Kutak. Dr. Kutak used the Real Property Inventory of 1938 to get the material for his study.

A summary of population of census tracts $48,57,58$ and 59 was made from the Real Property Inventory of 1938. The total population and the density of population in each census tract are summarized in the following table:

\section{TABIE I}

TOTAL POPULATION AND DENSITY OF POPULATION IN CENSUS TRACTS $48,57,58$, and 59

\begin{tabular}{ccc}
\hline Census Tract & Total Population & Density Per Square Milo \\
\hline 48 & 1,411 & 5,898 \\
57 & 5,702 & 29,308 \\
58 & 2,978 & 28,886 \\
59 & 4,925 & 43,192 \\
\hline
\end{tabular}




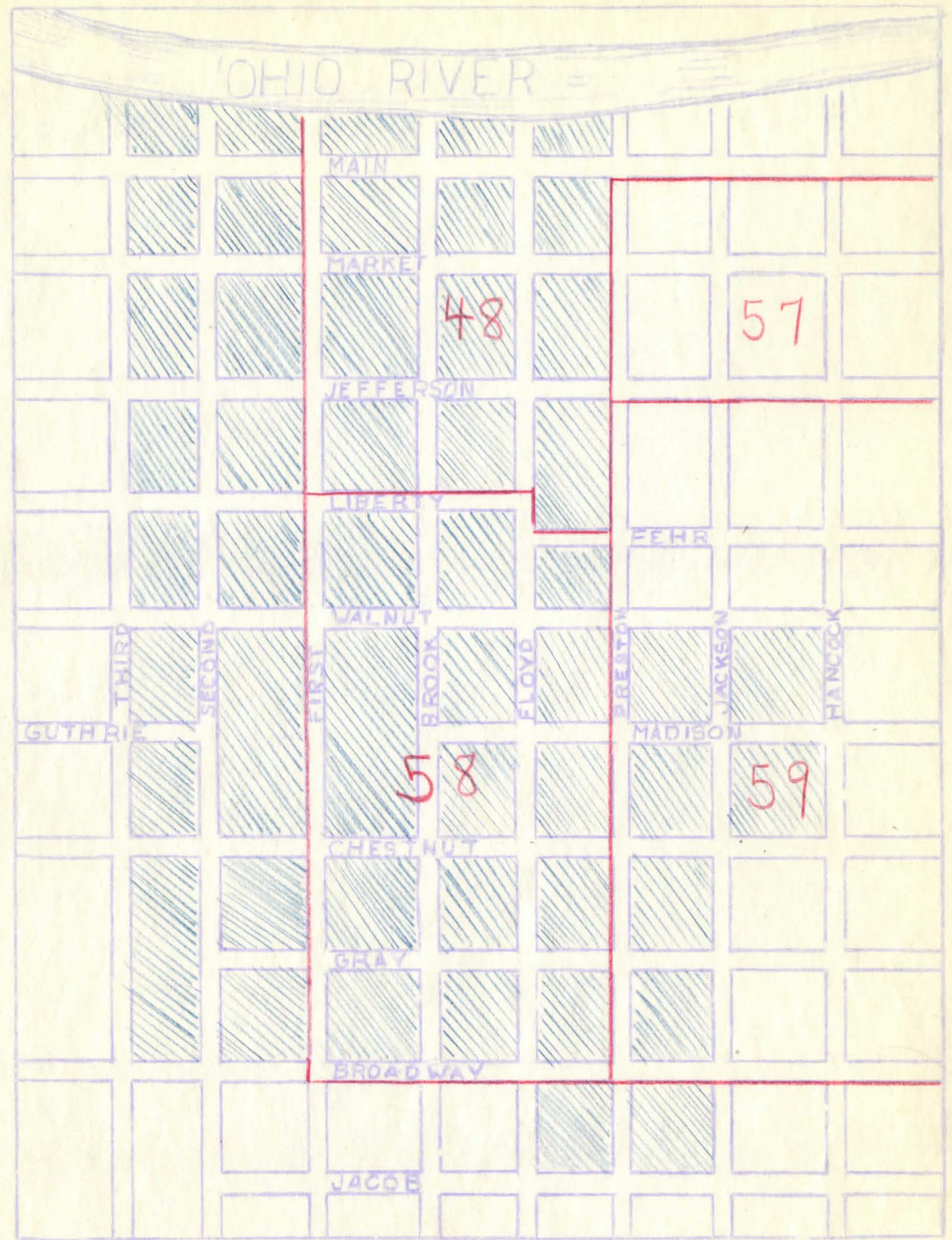

MAP OF THE GEORGE W. MORRIS SCHOOL DISTRICT SHOWING THE RELATIONSHIP OF THE SCHOOL DISTRICT TO CENSUS TRACTS $48,57,58,59$

Legend 
It has been shown that part of the Morris School district borders the Ohio River and that this area is occupied by a portion of the municipal dock, by a branch of a railroad, by a sand company and also that this section is devoted to industry and comerce. Therefore, these conditions account for the relatively low density of census tract 48. The relatively low density of census tract 58 may be accounted for by the fact that the George W. Morris Sohool, two hospitals and a tuberculosis clinic, a medical school, a school of dentistry and pharmacy and eight agencies for social welfare are situated in this area.

Dr. Kutak in his study makes the following conclusion:

The conclusion is inevitable that the population in the neighborhood adjacent to Christ Church Cathedral is too dense for the people to live comfortably in the type of housing accomodations available to them. The slum clearance project now under way will bring decent housing without congestion to a small part of the population. It can be considered only a demonstration of what may be done, rather than a complete solution to the housing problems confronting all of the people who live in this neighborhood.

Therefore, this study shows that the children who attend the Morris School come from a crowded congested area where they have to live in crowded, cramped quarters. This condition should be recognized in planning the personnel work of the Morris School and in trying to overcome and treat the problems of maladjustments which the pupils of this community present to the school. 
Composition of the population of the Morris Sohool neighborhood may be shown in a study of the age groups. The age distribution in census tracts $48,57,58$, and 59 is given in the following table:

TABLE II

AGE DISTRIBUTION OF POPULATION IN CENSUS

TRACTS $48,57,58$, and 59

\begin{tabular}{lcccccc}
\hline \hline & \multicolumn{7}{c}{ Census } & Traots & & \\
Age group & 48 & 57 & 58 & 59 & Total & Per oent \\
\hline Under 1 year & 21 & 132 & 40 & 75 & 268 & 1.2 \\
1 to 4 years & 57 & 343 & 125 & 259 & 784 & 5.2 \\
5 to 9 years & 103 & 415 & 156 & 374 & 1,048 & 7.3 \\
10 to 14 years & 94 & 522 & 182 & 385 & 1,183 & 8.0 \\
15 to 19 years & 100 & 451 & 181 & 347 & 1,079 & 7.3 \\
20 to 64 years & 994 & 3,604 & 2,158 & 3,307 & 10,063 & 67.1 \\
65 and over & 42 & 235 & 136 & 178 & 591 & 3.9 \\
\hline Totals & 1411 & 5,702 & 2,978 & 4,925 & 15,016 & 100.0 \\
\hline \hline
\end{tabular}


Sereral things may be noted from this table. First, that 21.4 per cent of the population of these four census tracts is under 14 years of age and 78.3 per cent is over 14 years of age. Second, It may be noted that the two age groups that more nearly coincide With the children of elementary school age represent only 15.3 per cent of the total population.

Dr. Kutak found that in the six census tracts studied for every hundred chfldren there were three hundred adults. For the United States as a whole in 1930 there were one hundred children for one hundred adults. This shows that for this district the proportion of children to adults is abnormal. In Chapter II it was pointed out that Burgess thought that in a decline of a neighborhood there were eight stages and the eighth or final stage was when business or industry takes full possession of the area. Table II shows that in this district the proportion of children to adults is abnormal. Two questions may arise out of this, first, is this an indication that this district is approaching the last stage of decline and second, if this be so how much longer will there be a need for a school in this oommunity.

The dwolling unfts by ownership and tenancy in census tracts $48,57,58$, and 59 is given in the following table. 
TABLE III

DWELIING UNITS BY OWNERSHIP AND TENANCY IN CENSUS TRACTS $48,57,58$, and 59

\begin{tabular}{cccc}
\hline Census Tract & Owner Occupied & Occupied by Tenant & Total \\
\hline 48 & 37 & 424 & 461 \\
57 & 190 & 1,536 & 1,726 \\
58 & 79 & 966 & 1,045 \\
59 & 163 & 1,350 & 1,513 \\
& & & 4,745 \\
\hline Totals & 469 & 4,276 & \\
\hline
\end{tabular}

With respect to dwelling units only 9.8 per cent are owned by occupants and 91.2 per cent are rented. For the city as a whole in $1938,37.7$ per cent of all occupied dwelling units were owned by oocupents and 62.3 per cent were rented by tenants. The fact that in this district 28.9 per cent more of the dwolling units are rented than for the city as a whole indicates the mobility of the neighborhood and also indicates that the school is faced with problems of pupil adjustment which grow out of a shifting population..

Table IV gives the population in owner-occupied and rented dwelling units in consus tracts $48,57,58$, and 59. 
TABLE IV

POPULATION IN OHNER-OCCUPIED AND RENTED DWELLTNG

UNITS IN CENSUS TRACTS $48,57,58$, and 59

\begin{tabular}{cccc}
\hline Census Tract & Owner Ocoupied & Ocoupied by Tenant & Total \\
\hline 48 & 134 & 1,277 & 1,411 \\
57 & 650 & 5,052 & 5,702 \\
58 & 318 & 2,660 & 2,978 \\
59 & 618 & 4,307 & 4,925 \\
& 1,720 & 13,296 & 15,016 \\
\hline
\end{tabular}

This table shows that only 11.4 per cent of the population of census tracts $48,57,58$, and 59 live in owner-occupied dwellings and 88.6 per cent live in rented dwellings. The fact that 88.6 per cent of the population live in rented dwellings is another indication of the high rate of mobility of the district.

Dr. Kutak found that the median occupancy for the people who live in census tracts $48,57,58,59,60$, and 73 is 2.1 years while for the inhabitants of Louisville it is 3.6 years. However, this part of his study dealt only with family dwelling units and did not include the rooming houses. Since the Morris School district contains many rooming houses where the mobility may be expected to be very high it may be concluded that the mobility in this distriet 
is much higher than these figures indicate. This leads us to the conolusion that the Morris Sohool district must have many problems growing out of a shifting, changing population.

In a community as crowded and having as high rate of mobility as the Morris School district, even though the proportion of children to adults as compared to the United States is abnormal, it may be expected that the rate of delinquency is high as compared with the City of Louisville as a whole.

During the winter of 1935 , one of the W.P.A.1 projects was a study of Juvenile Delinquency in the city. The sources of information were the Juvenile Court and the Police Court. The study of delinquency was made by census tracts $48,57,58$, and 59 . In this study only the jurenile delinquents who appeared before the jurenile court during the year 1935 were included. The following table shows the number of jurenile delinquents before the Juvenile Court in Louisville, Kentucky, by race and sex in 1935.

I A Study of Juvenile Delinquency in Iouisville, 1935. Made as a M.P. A. Project. Files--Community Chest Headquarters. 


\section{TABLE V}

NUBBER OF JUVENILE DELINQUENTS BEFORE THE JUVENILE COURT BY RACE AND SEX IN THE CITY OF IOUISVILLE, 1935

\begin{tabular}{lccc}
\hline & Thite & Negro & Total \\
\hline Malo & 368 & 256 & 624 \\
Fomalo & 98 & 38 & 136 \\
& & & 760 \\
\hline
\end{tabular}

It should be remembered that this table represents only the juvenile delinquents who appeared before the court in 1935 and probably there were many more children committing delinquent acts in the city than this table represents.

The next table shows the number of jurenile delinquents before the Juvenile Court in census tracts $48,57,58$, and 59 in 1935. 


\section{TABLE VI}

NUMBER OF JUVENILE DELINQUENTS BEFORE THE JUVENILE COURT IN CENSUS TRACTS $48,57,58$, and 59 , in 1935

Consus Pract 48

57

58

59
Number Jurenile Delinquents

Table I shows that the density of population per square mile of consus tracts 48 and 58 was small as oompared with census tract 57 and 58. The reason for this is that census tract 48 is composed mostly of commercial and produce houses and census tract 58 contains a number of buildings for educational social welfare purposes. From a comparison of Tables $V$ and VI census tracts $48,57,58$, and 59 oontributed 7.5 per cent of the number of juveniles who appeared before the Juvenile Court during the year 1935 as compared with the rest of the city.

Table VII shows the number of Juvenile delinquents as compared with the number of major and minor crimes in census tracts 48,67 , 58 , and 59 in 1935 
TABIE VII

JUVENILE DELINQUENCY COMPARED WITH MAJOR AND MINOR CRIMES BY CENSUS TRACTS $48,57,58$, and 59 in 1935

\begin{tabular}{cccc}
\hline \hline Census Tract & $\begin{array}{l}\text { Number } \\
\text { Juvenile } \\
\text { Delinquents }\end{array}$ & $\begin{array}{l}\text { Number } \\
\text { Najor } \\
\text { Crimes }\end{array}$ & $\begin{array}{l}\text { Number } \\
\text { Minor } \\
\text { Crimes }\end{array}$ \\
\hline 48 & 5 & 21 & 79 \\
57 & 19 & 16 & 61 \\
58 & 8 & 15 & 60 \\
59 & 25 & 14 & 60 \\
\hline
\end{tabular}

This table shows that consus tracts $48,57,58$ and 59 for the year 1935 show a larger number of major and minor orimes than the number of jurenile delinquents. This is to be expected since the persons committing major and minor crimes are more certain to get before the court than are the jurenile delinquents.

The following two tables show the rank of census tracts 48 , 57,58 , and 59 in magnitude of delinquency and of major crimes and minor crimes as compared with the 80 census tracts of the ofty. 
TABLE VIII

RANK OF CENSUS TRACTS $48,57,58$, and 59 IN MAGNITUDE OF DELINQUENCY WITH THE 80 CENSUS TRACTS OF THE CITY, 1935

\begin{tabular}{lcc}
\hline $\begin{array}{l}\text { Census } \\
\text { Tract }\end{array}$ & $\begin{array}{l}\text { Number } \\
\text { Juvenile Delinquents }\end{array}$ & $\begin{array}{l}\text { Rank of Consus Tracts } \\
\text { with } \\
\text { of City Census Tracts }\end{array}$ \\
\hline 48 & 5 & 19 \\
57 & 19 & 7 \\
58 & 8 & 16 \\
59 & 25 & 3 \\
\hline
\end{tabular}

Table I showed that census tracts 48 and 58 as compared with 57 and 59 had a relatively low density of population per square mile. This in a degreo accounts for the small number of juvenile delinquents in census tracts 48 and 58 . However, census tract 48 ranks nineteenth and census tract 58 ranks sixteenth with the eighty census tracts of the city. Table I also shows the extreme density of population per square mile of census tracts 57 and 59 and Table VII shows that census tract 57 ranks seventh and consus traot 59 ranks third in comparison with the eighty census tracts of the oity.

The following table shows the rank of census tracts 48,57 , 58 , and 59 in magnitude of delinquency of major and of minor crimes as compared with the eighty census tracts of the city. 
TABLE IX

RANK OF CENSUS TRACTS $48,57,58$, and 59 IN MAGNITUDE

OF DELINQUENCY, OF MAJOR CRIMES AND OF MINOR CRIMES

WITH THE 80 CENSUS TRACTS OF THE CITY, 1935

\begin{tabular}{lccc}
\hline & \multicolumn{2}{c}{ Rank with 80 Consus Tracts of City } \\
\cline { 2 - 4 } $\begin{array}{l}\text { Census } \\
\text { Tract }\end{array}$ & $\begin{array}{l}\text { Juvenile } \\
\text { Delinquency }\end{array}$ & $\begin{array}{c}\text { Najor } \\
\text { Crimo }\end{array}$ & $\begin{array}{c}\text { Minor } \\
\text { Crime }\end{array}$ \\
\hline \hline 58 & 19 & 13 & 7 \\
57 & 7 & 4 & 4 \\
58 & 16 & 5 & 6 \\
59 & 3 & 6 & 5 \\
\hline
\end{tabular}

This table shows that the Morris School Neighborhood not only ranks high in juvenile delinquency but also in the magnitude of major and minor crimes as compared with the 80 census tracts of the city. Both tables VIII and IX show that census tracts $48,57,58$, and 59 in both jurenile delinquents and major and minor crimes in the upper quartile as compared with the elghty census tracts of the city. The following conelusions may be drawn from a study of these tables:

1. The Morris School is situated in a nejghborhood where the population is so dense that the people cannot live comfortably in the 
type houses available to them.

2. The proportion of ohildren to adults in the district as compared with the proportion in the United States in 1930 indicates that there is an abnormal proportion of adults to children. This may indicate that in future years there may be no need for an elementary school in this district and means that probably in considering a school building program for the city it would be poor economy to build a new school in this area.

3. The fact that 88.6 per cont of the population of this district live in rented dwellings and that this does not include the number who live in rooming houses indicates that the mobility of the neighborhood is extremely high.

4. The study on juvenile delinquency and major and minor crimes show that the four census tracts rank in the upper fourth when compared with the 80 census tracts of the city. This indieates that this neighborhood ranks high in juvenile delinquency and in major and minor crimes as compared with the rest of the eity.

These conclusions point to certain probable factors which contribute toward maladjustment in children. Maladjustments which will be reflected in their behavior at school and maladjustments which the school will have to either overcome or attempt to mitigate as far as possible if the children are going to gain real benefit from their educational opportunitios. The causes of these maladjustments are the effects of over crowding, the effects of the high mobility of 
the neighborhood and the effects of living in a community that ranks high in jurenile delinquency as well as in major and minor crimes. How these problems are dealt with and treated will be shown later in this thesis. 
CHAPTER IV

SOME FACTORS AFFECTING FAMILY IIFE IN THE GEORGE W. MORRIS SCHOOL DISTRICT 


\section{CHAPTER IV}

\section{SOME FACTORS AFFECTING FAMILY LIFE IN THE \\ GEORGE W. MORRIS SCHOOL DISTRICT}

It is desirable for a school not only to have a knowledge of the community in which it is located but it is also desirable for the school to have a knowledge of some of the factors affecting the family life of the families represented in the school. The school should know how many of its children come from homes where the parents are not employed; how many come from homes where the family is receiving relief; how many come from homes known to social agencies; how many come from homes where the mother is gainfully employed outside of the home; and how many come from homes broken through death, divorce, or separation. This type information is important because it helps the school to recognize and to solve as far as possible the need of school clothing for children; to realize the necessity of keoping friendly working relations with social agencies; to recognize the extent of the problem of caring for children who become sick at school and whose mothers work outside the home; and also to realize the need for planned supervision of children after school hours.

For the above reasons a study dealing with some of these factors was made of the Morris School population. This study included only the familles of the children who attended the Morris School during the school year 1938-1939. There were 608 children enrolled in the sohool. 
However, 28 of these children came from the Home of the Innocents ${ }^{2}$ and beceuse they were not normally a part of the school neighborhood and because, as a rule, they attended for only a short period, some for only a fow days, they were omftted from the study. Five hundred and eighty children coming from 394 families were included in the study. The information for this sudy was obtained by the risiting teacher visiting the families and getting the information through direct and indirect interviews and through information obtained through the social service exchange. 2

The first study derls with the economic status of the families represented in the school. The following table gives this information.

1 Home of the Innocents, an Episcopal Home for the temporary care of white children.

2 Social Service Exchange, a clearing house for soclal agencies. 
TABLE $X$

THE ECONOMIC STATUS OF THE 394 FAMILIES REPRESENTED IN THE GEORGE W. MORRIS SCHOOL DURING THE SCHOOL YEAR 1938-1939, SHOWING WHETHER THE MOTHER, FATHER OR BOTH WERE EMPLOYED, THE NUMBER OF FAMIIIES ON RELIEF, AND THE NUNBER OF FAMILIES HAVING NO EMPIOYMENT AND ALSO SHOWING THE NOMBER OF CHIIDREN IN EACH CIASSIFICATION

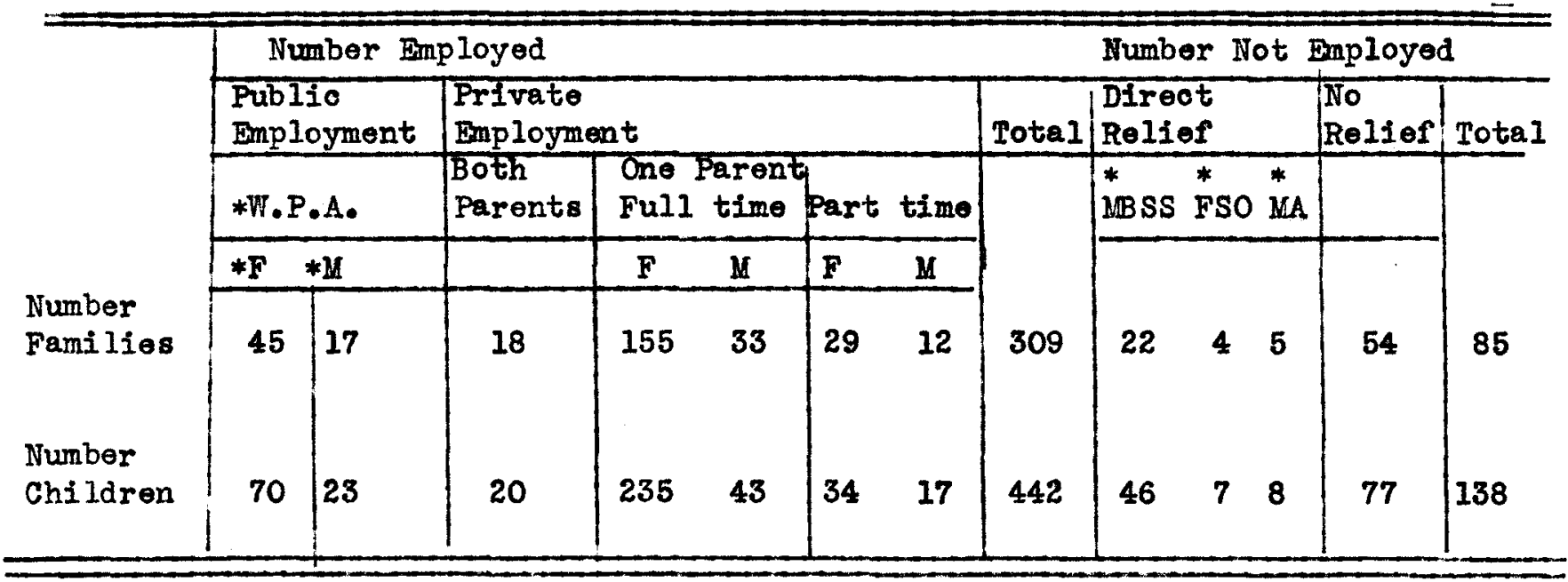

*W.P.A. - Works Progress Administration

*F. - Father

*M. - Mother

*M.B.S.S.- Municipal Bureau of Social Service

*F.S.0. - Family Service Organization

*M.A. - Mother's Aid 
Table X shows that of the 394 families, 309 , or 78.4 per cont were employed and 85 , or 21.1 per cont were not employed.

or the 394 families, 62 , or 15.7 per cent were employed on W.P.A. work projects. Fifty-one of these families received $\$ 22.40$ twice a month, and the remaining eleven were in a higher pay bracket. In the families with private employment, 18 , or 4.5 per cent of the families where both parents were employed sixteen of the mothers were working because the father's income was inadequate for the minimum need of the famfly. One hundred and eighty-elght or 47.7 per cent of the families had either the mother or father employed full time. Forty-one, or 10.4 per cent of the families had one parent employed part time. In none of these families where one parent received part time omployment did the income reach the minimum standard budget ${ }^{3}$ requirements.

In the families where there was no employment, 31 , or 7.8 per cent were on direct relief, and 54 , or 13.1 per cent were not omployed. The Family Service Organization was active in more than the four families indicated, but only in these families was this organization the only source of income. In the five fanilies receiving Mother's Ald there was no other source of income. There was no other source of income in the 22 families receiving direct

3 Minimum Standard Budget - This is a budget which maintains a minimum of health and decency level. It allows subsistence plus a few comforts. Gavin, Ruth W., Gray, A.A., Groves, Ernest R.. Our Changing Social Order, p. 210 
relief from the Municipal Bureau of Social Service.

Nine of the children included in the study lived with relatives, but since in each case the head of the household accepted the responsibility of the child, these children were considered as members of the families. In the 309 families which had employment, there were 442 , or 76.3 per cent of the total number of 580 children.

In the 62 families receiving W.P.A. employment, there were 93, or 16 per cent of the children; in the 18 farnilies where both parents were employed there were 20 or 3.4 per cent of the children; in the 188 families where one parent received full time private employment, there were 278 , or 47.7 per cent of the children; and in the 41 families where one parent had part tine private employment, there were 51 or 8.9 per cent of the children.

In the 31 families on direct relief, there were 61 or 10.3 per cent of the children, and of the 54 families having no employment or receiving no relief, there were 77 , or 13.2 per cent of the total number of children.

Table X shors the number of homes where one or both parents were employed by private employment. Table XI gives an analysis of the families who received full time private employment showing the number who lived on at least a minimum standard budget and the number who lived on below this budget. 
TABLE XI

AN ANALYSIS OF THE 206 FAMTLIES REPRESENTED IN THE GEORGE W. MORRIS SCHOOL WHERE BOTH OR ONE PARENT HAD FULI TIME PRTVATE EAPLOYMEHT SHOWING THE NUMBER WHO IIVED ON AT IEAST A MINIMUN STANDARD BUDGET, 1 AND THE NUMBER WHO LIVED ON IESS THAN A MINIMOM STANDARD BUDGET AND ALSO SHONTNG THE NUMBER OF CHIIDREN IN EACH CLASSIFICATION

Full Time Private Employment - 206 Families

\begin{tabular}{|c|c|c|c|c|c|c|c|}
\hline & \multicolumn{4}{|c|}{ Minimum Budget or Above } & \multicolumn{3}{|c|}{ Below Minimum Budget } \\
\hline & $\begin{array}{l}\text { Both } \\
\text { Parents } \\
\text { Employed }\end{array}$ & $\begin{array}{l}\text { Only } \\
\text { Father } \\
\text { Employed }\end{array}$ & $\begin{array}{l}\text { Only } \\
\text { Mother } \\
\text { Employed }\end{array}$ & Total & $\begin{array}{l}\text { Only } \\
\text { Father } \\
\text { Employed }\end{array}$ & $\begin{array}{l}\text { Only } \\
\text { Mother } \\
\text { Bmployed }\end{array}$ & Total \\
\hline $\begin{array}{l}\text { Number } \\
\text { Families }\end{array}$ & 18 & 144 & 13 & 175 & 11 & 20 & 31 \\
\hline $\begin{array}{l}\text { Number } \\
\text { Children }\end{array}$ & 20 & 201 & 20 & 241 & 25 & 32 & 57 \\
\hline
\end{tabular}

1 Budget of Aid to Dependent Children, Department of Louisville and Jefferson County used as guide. 
In the 206 families where both or one parent had full time private employment, 175 families, or 84.9 per cont earned at loast a minimum standard budget and in 31 families or 15 per cent the earnings did not meet the minimum standard requirements.

In 18 families or 8.6 per cent both parents were employed and together their earnings at least met the standard minimum budget requirements; in 144 families or 6.9 per cent only the father was employed and his earnings at least met the minimum standard budget requirements; in 13 families or 6.3 per cent only the mother was omployed and her earnings at least met the minimum standard budget requirements. In 11 families or 5.6 per cent the father had full time employment but his earnings did not meet the minimum standard budget requirements; and in 20 families, or 9.7 per cent the mother had full time employment but her earnings did not meet the minimum standard budget requirements.

of the total number of 298 children in the 206 families where both or one parent had full time private employment, 241 children or 80.8 per cent lived in families where the budget at least met the minimum standard budget requirements and 57 of the children or 19 per oent lived in families where the earnings did not reach the minimum standard budget requirements.

Twenty children or 6.7 per cent lived in families where both parents were employed and their combined earnings at least reached the minimum standard budget requirements; 201 children or 67.4 per 
cent lived in families where only the father was employed and his earnings at least met the minimum standard budget requirements; and 20 children or 6.7 per cent lived in families where only the nother was employed and her earnings at least met the minjmum standard budget requirements. Twenty-five children or 8.3 per cent lived in families where only the father was employed but his earnings did not meet the minimum standard budget requirements and 32 children or 10.7 per cont lived in homes where only the mother wor and her income did not meet the minimum standard budget requirements.

It has been shown that 11 of the families employed on W.P.A. work projects were in a higher pay bracket than the common laborer on this type employment. These eleven families had earnings oufficient to meet the requirements of the standard minimum budget. It has also been show that in 175 of the families the earnings from private employment at least met the minimum standard budget requirements. This is a total of 186 families or 47.2 per cent of the total number of 394 families in which the earnings at least met the minimum standard budget requirements. In the 11 families employed on w.P.A. work projects there were 16 ohildren and in the 175 families having private employment there were 241 children, making a total of 257 children or 44.1 per cont living in 186 homes, or 47.2 per cent where the earnings at least met the minimum standard budget requirements. 
Fifty-four of the families in the unemployed group recoived no direct relief from any rolief agency. The following table gives an analysis of the type of support which these families had. 


\section{AN ANALYSIS OF THE TYPE OF SUPPORT OF THE 54 FAMILIES \\ REPRESENTED IN THE GEORGE W. MORRIS SCHOOL IN THE \\ UNEMPLOYED GROUP SHOWING THE NUMBER OF CHILDREN \\ IN EACH CLASSIFICATION}

\begin{tabular}{lcc}
\hline $\begin{array}{l}\text { Type } \\
\text { Support }\end{array}$ & $\begin{array}{c}\text { Number } \\
\text { Families }\end{array}$ & $\begin{array}{c}\text { Number } \\
\text { Children }\end{array}$ \\
\hline Federal Government Pension & 7 & 10 \\
Daughter on N.Y.A.* & 1 & 1 \\
Son in C.C.C.* & 1 & 2 \\
Unemployment Insurance & 2 & 4 \\
Savings & 8 & 10 \\
Alimony & 2 & 20 \\
Older Child ren Iiving at Home & 11 & 17 \\
Relatives & 14 & 2 \\
Landlord & 2 & 8 \\
No Evident Means & 6 & 77 \\
\hline Totals & 54 & \\
\hline
\end{tabular}

* N.Y.A. - National Youth Administration

* C.C.C. - Civilians Conservation Core 
In one family receiving a government pension, the income met the minimum standard budget requirements. The daughter on N.Y.A. recoived $\$ 3.50$ a weok. There were three in this family. Ono family received $\$ 25.00$ a month from the son who was in C.C.C. There are six in this family.

In the two families receiving the unemployment insurance the amount of the insurance met the minimum standard budget requirements. However, both families were burdened with debt and used some of their income to help pay off these debts. The savings of the eight families were very small and because there was no prospect for work they used their savings very sparingly.

In the two families where the sarce of income was alimony, the income did not meet the minimum standard budget requirements. In three of the families where the older children supported the family the income met the requirements for the minimum standard budget. In no instance where the relatives helped did the families have enough to meet their needs. Also this help was not regular. In two families the rooming house landlord gave the families lodging and food. In all of the families where the income did not meet the family needs, the families received additional help from government commodities, from the Volunteers of America, from churches and the school.

In a district where there are as many signs of disorganization and disintegration as in the Goorge . Mor ris School district, it is to be expected that many of the children come from homes broken through death, divorce, separation and desertion. The following table gives this information. 
TABLE XIII

AN ANALYSIS OF THE BROKEN HOMES ${ }^{1}$ IN THE 394 HOMES REPRESENTED IN THE GEORGE W. MORRIS SCHOOL SHOWING THE CAUSE, THE NUMBER OF HOMES BROKEN AND THE NUMBER OF CHILDREN AFFECTED

\section{Cause}

Homes Broken Through:

\begin{tabular}{|c|c|c|c|c|}
\hline $\begin{array}{l}\text { Death } \\
\text { of : }\end{array}$ & $\begin{array}{l}\text { Desertion } \\
\text { of : }\end{array}$ & $\begin{array}{l}\text { Separation } \\
\text { or Divorce } \\
\text { Children } \\
\text { With: }\end{array}$ & $\begin{array}{l}\text { One Parent In } \\
\text { Government } \\
\text { Institution }\end{array}$ & Total \\
\hline . ${ }^{*}$. ${ }^{*}$. & F. M. B. & F. M. & F. & \\
\hline
\end{tabular}

Number

Families

$\begin{array}{llllllll}31 & 7 & 5 & 28 & 2 & 2 & 13 & 61\end{array}$

41

Number

Children

4015

6

402

2

$13 \quad 87$

61

212

1 Broken homes - homes in which through death, desertion, separation or divorce one of the parents is out of the home.

* F. - Father

M. - Mother

B. - Both 
of the 394 families included in this study, 154 families or 39 per cent were broken.

Of the 154 families which were broken 43 families or 27.9 per cent were broken through death of one or both parents; 32 families or 20.8 per cent were broken through the desertion of one or both parents; 74 families or 48.1 per cent were broken through separation or divorce; and 5 homes or 3.2 per cent were broken by one parent being in a government institution. of this last group, the four fathers were in prison and the mother in a mental hospital.

In eight families in the Norris Sohool the father was in the home. Six of these fathers were habitual drun ards, two were mental cases and one deserted frequently. In each case the father was such a disorganizing influence that it may be considered that these homes were broken or perhaps worse than broken.

In the families which were broken through death or separation 36 of the parents or 22.2 per cent remarried.

The divorce rate in 1935 for the United States per 100 marriages was 16.4 per cont. ${ }^{4}$ The rate in the Morris School for divorces and separation for the school year 1938-39 was 39 per cent. Although this is not a valid comparison it indicates that the number of broken homes due to separation and divorce in the Morris School district was relatively high.

\footnotetext{
4 World Almanac and Book of Facts, New York World-Telegram, 1940. p. $-\overline{510}$
} 
of the 580 children included in the study, 212 children or 36.5 per cent lived in homes that were brolien.

In four of the families the mothers were dead and the fathers had deserted. Six children were affected. These children were cared for by relatives, two by a maternal grandmother, two by a married sister, one by a peternal uncle, and one by a paternal aunt.

of the 212 children who lived in broken homes, 61 or 28.9 per cent lived in homes broken through death; 44 children or 20.8 per oent Iived in homes broken through desertion; 100 children, or 47.2 per oent lived in homes broken through separation or divorce; and 7 children or 3.4 per cent lived in homes broken by one parent being in a government institution.

of the 212 children included in the study in 36 of the homes where 50 or 23.6 per cent of the children lived, one parent had remarried and the step-parent lived in the home.

Because of the low economic status of the families represented in the George W. Morris School many of the mothers seek employment outside the home. Having the mother out of the home for the major part of the day creates many problems. One of the outstanding problems is the care of the children while the mother is out of the home. Table XIV is a statistical study showing the extent of these problems for 1938-1939. 
THE NUMBER OF FAMILIES AND NUMBER OF CHILDREN IN THE GEORGE W. MORRIS SCHOOL IN WHJCH THE MOTHER WAS GAINFULLY EMPLOYED SHOWING THE STATUS OF THE FATHER AND GIVING AN ANALYSIS OF HOW MUCE PLANNED CARE THE CHILDREN RECEIVED WHILE THE MOTHERS WERE OUT OF THE HOME

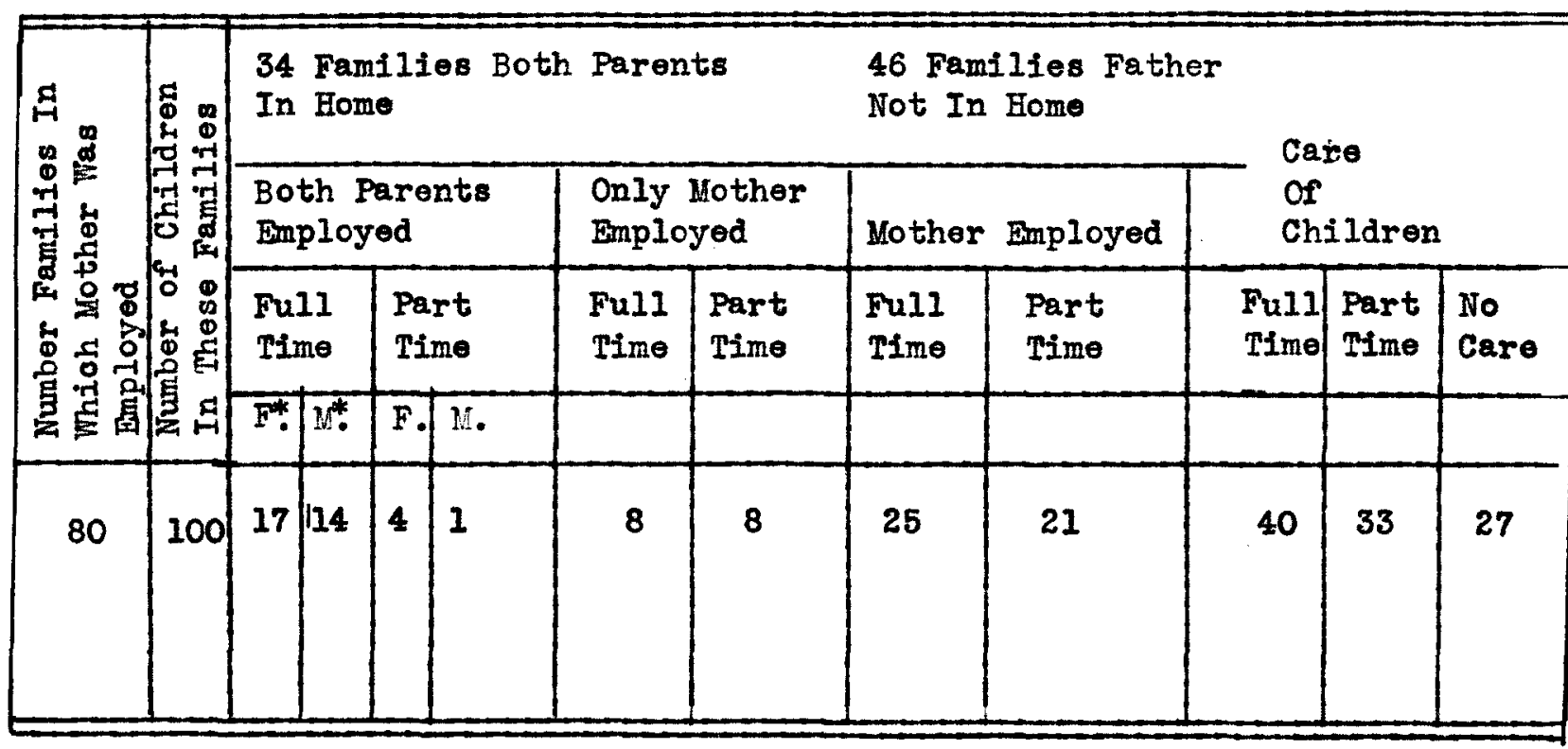

* F. - Father

* M. - Mother 
of the 394 families included in the study, 80 families or 20.3 per cent have the mother gainfully employed. Of the 80 families, 34 , or 42.4 per cent have the father in the home, and 46 families or 57.5 per cent do not have the father in the home.

In the 80 families, 18 or 22.5 per cent had both parents in the home and both parents employed; 16 families, or 20 per cent had both parents in the home, but only the mother employed; and 46 families, or 57.5 per cent had no father in the home and the mother was employed either full time or part time.

Of the 100 children in these homes, 40 children, or 40 per cent had full time care; 33 children or 33 per cont had part time care, and 27 ohildren or 27 per cent had no care at all.

Of the 40 children who received full time care, 9 were cared for at the Union Gospel Mission, 5 twenty-one were cared for by their fathers, 9 were cared for by the maternal grandmother and 2 were cared for by paid help in the home.

In Philadelphia in 1928 a study was made of children of working mothers. The principal object of the inquiry was to ascertain the relationship between the employment of mothers and the welfare of their children. Eleven districts in different parts of Philadelphia wero selected for study as examples of various types of wage-earning

5 Union Gospel Mission provides day care for white children. 
neighborhoods of the city. It was found that in the selected areas of the city included in the study, 21 per cent of the white mothers with husbands and one or more children under 16 years of age living at home were employed. The study makes the following conclusion:

Apart from economic necessity, apparently the outstanding consideration in determining whether or not a mother went to work was the age and number of children. The proportion of mothers employed varied directly with the number of children and with the presence of children of pre-school age. The indications are that the mothers of children who require constant supervision and mothers of large families do not go to work except as a last resort. They then try to obtain work at night or at hours that interfere the least with their duties as mothers. Mothers who must earn to keep their families together, however, will work even if the children are neglected. It is a choice betweon food and clothing for the children and their adequate supervision. 6

It will be noted that in the Morris School neighborhood 20.3 per cent of the mothers worked out of the home while in the Philadelphia study 21 per cent worked out of the home. It will also be noted that the study of the Morris school neighborhood included homes with fathers in them as well as homes where there were no fathers while the study in Philadelphia included only the homes where the father was present.

In a sohool where 52.8 per cent of the families did not have a budget that met the minimum standard requirements, where 39 per cent of the homes were broken through death, separation, divorce or

6 Beyer, Clara M., Children of Working Mothers in Philadelphia, Government Document, United States Department of Labor, Washington, 1931. 
desertion, in a school where 20.3 per cent of the mothers were gainfully employed it is to be expected that many of the families were known or had been known to the various social agencies. Table XV gives a statistical picture of the number of families known to the social agencies. 
THE NUMBER OF FAMILIES REPRESENTED IN THE GEORGE W. MORRIS SCHOOL DISTRICT KNOWN TO SOCIAL AGENCIES, SHOWING THE NOMBER OF FAMIIIES IN WHICH AGENCIES WERE ACTIVE DURING THE SCHOOL YEAR 1938-1939, THE NOMBER OF FAMILIES KNOWN TO AGENCIES PRIOR TO THAT YEAR AND THE NUMBER OF FAMILIES ON WHICH THE AGENCIES ONLY CIEARED

\begin{tabular}{|c|c|c|c|c|c|c|c|c|c|}
\hline \multicolumn{10}{|c|}{ Number Families Known To Family Nelfare And Relief Agencies } \\
\hline & FSO* & MBSS* & MA* & JWA* & $L A *$ & LGI* & SA* & St. VdeP* & TA* \\
\hline $\begin{array}{l}\text { Active During } \\
\text { School Year } \\
1938-39\end{array}$ & 22 & 27 & 4 & 1 & 25 & 2 & 3 & & 3 \\
\hline $\begin{array}{l}\text { Known Family } \\
\text { Prior To That } \\
\text { Year }\end{array}$ & 137 & 111 & 9 & 15 & 114 & 14 & 26 & 7 & 16 \\
\hline $\begin{array}{l}\text { Cleared On } \\
\text { Family Only }\end{array}$ & 10 & 55 & & & & & & 1 & \\
\hline \multirow[t]{3}{*}{ Total } & 169 & 193 & 13 & 16 & 139 & 16 & 29 & 8 & 19 \\
\hline & \multicolumn{9}{|c|}{ Number Families Known To Health Agencies } \\
\hline & $\overline{\mathrm{BT}}$ & & LCHS & & $\overline{\mathrm{CFH}}$ & SS* & NNI & MHC* & PHNA* \\
\hline $\begin{array}{l}\text { Aotive During } \\
\text { Sohool Year } \\
\text { 1938-39 }\end{array}$ & 2 & & 5 & & 2 & & 1 & 2 & 13 \\
\hline $\begin{array}{l}\text { Known Family } \\
\text { Prior To That } \\
\text { Year }\end{array}$ & 36 & & 38 & & 66 & & 1 & 20 & 115 \\
\hline Total & 38 & & 43 & & 68 & & 2 & 22 & 128 \\
\hline
\end{tabular}


TABLE XV (continued)

THE NUMBER OF FAMILIES REPRESENTED IN THE GEORGE MORRIS SCHOOL DISTRICT KNOWN TO SOCIAI AGENCIES, SHONING THE NUMBER OF FAMILIES IN WHICH AGENCIES WERE ACTIVE DURING THE SCHOOL YEAR 1938-1939, THE NUMBER OF FAMIIIES WNOWN TO AGENCIES PRIOR TO THAT YEAR AND THE NOMBER OF FAMIIIES ON WHICH THE AGENCIES ONLY CLEARED

\begin{tabular}{|c|c|c|c|c|c|c|c|c|c|c|}
\hline \multicolumn{11}{|c|}{ Number Families Known To } \\
\hline$\overline{2}$ & \multicolumn{4}{|c|}{ *I \& JCCH } & \multirow[b]{2}{*}{$\mathrm{CA} *$} & \multirow[b]{2}{*}{ HI * } & \multirow[b]{2}{*}{ UGM* } & \multirow[b]{2}{*}{$\mathrm{NH} *$} & \multirow[b]{2}{*}{ WH* } & \multirow[b]{2}{*}{ LFAH* } \\
\hline & $\mathrm{JC}$ & $\mathrm{DH}$ & FH & or & & & & & & \\
\hline $\begin{array}{l}\text { Active During } \\
\text { Sohool Ieat } \\
1938-39\end{array}$ & 25 & 9 & & 5 & 7 & & 7 & 8 & 1 & 6 \\
\hline $\begin{array}{l}\text { Known Family } \\
\text { Prior To That } \\
\text { Year }\end{array}$ & 76 & 40 & 5 & 15 & 51 & 17 & 24 & 16 & & \\
\hline $\begin{array}{l}\text { Cleared on } \\
\text { Family only }\end{array}$ & 2 & & & & & & & & & \\
\hline Total & 103 & 49 & 5 & 20 & 58 & 17 & 31 & 24 & 1 & 6 \\
\hline
\end{tabular}




\section{TABLE XV (continued)}

THE NUMBER OF FAMIIIES REPRESENTED IN THE GEORGE MORRIS SCHOOL DISTRICT KNOWN TO SOCIAL AGENCIES, SHOWING THE NOUBER OF FAMILIES IN WHICH AGENCIES WERE ACTIVE DURING THE SCHOOL YEAR 1938-1939, THE NUMBER OF FAMILIES KNOWN TO AGENCIES PRIOR TO THAT YEAR AND THE NOMBER OF FAMILIES ON WHICH THE AGENCIES ONLY CLEARED

\begin{tabular}{|c|c|c|c|c|c|c|}
\hline \multicolumn{7}{|c|}{ Totals } \\
\hline & $\begin{array}{l}\text { Family Welfare \& } \\
\text { Relief Agenoles }\end{array}$ & Health & $\begin{array}{l}\text { Child } \\
\text { Welfare }\end{array}$ & Group & Other & Total \\
\hline $\begin{array}{l}\text { Aotive During } \\
\text { School Year } \\
1938-39\end{array}$ & 87 & 25 & 53 & 8 & 6 & 179 \\
\hline $\begin{array}{l}\text { Known Family } \\
\text { Prior To That } \\
\text { Year }\end{array}$ & 449 & 276 & 228 & 16 & & 969 \\
\hline $\begin{array}{l}\text { Cleared On } \\
\text { Family Only }\end{array}$ & 66 & & 2 & & & 68 \\
\hline Total & 602 & 301 & 283 & 24 & 6 & 1216 \\
\hline
\end{tabular}


TABLE XV (continued)

THE NUMBER OF FANILIES REPRESENTED IN THE GEORGE W. MORRIS SCHOOL DISTRICT KNOWN TO SOCIAL AGENCIES, SHONING THE NUMBER OF FAMIIIES IN WHICH AGENCIES WERE ACTIVE DURING THE SCHOOL YEAR 1938-1939, THE NOMBER OF FAMILIES KNONN TO AGENCIES PRIOR TO THAT YEAR AND THE NUMBER OF FAMILIES ON WHICH THE AGENCIES ONLY CLEARED

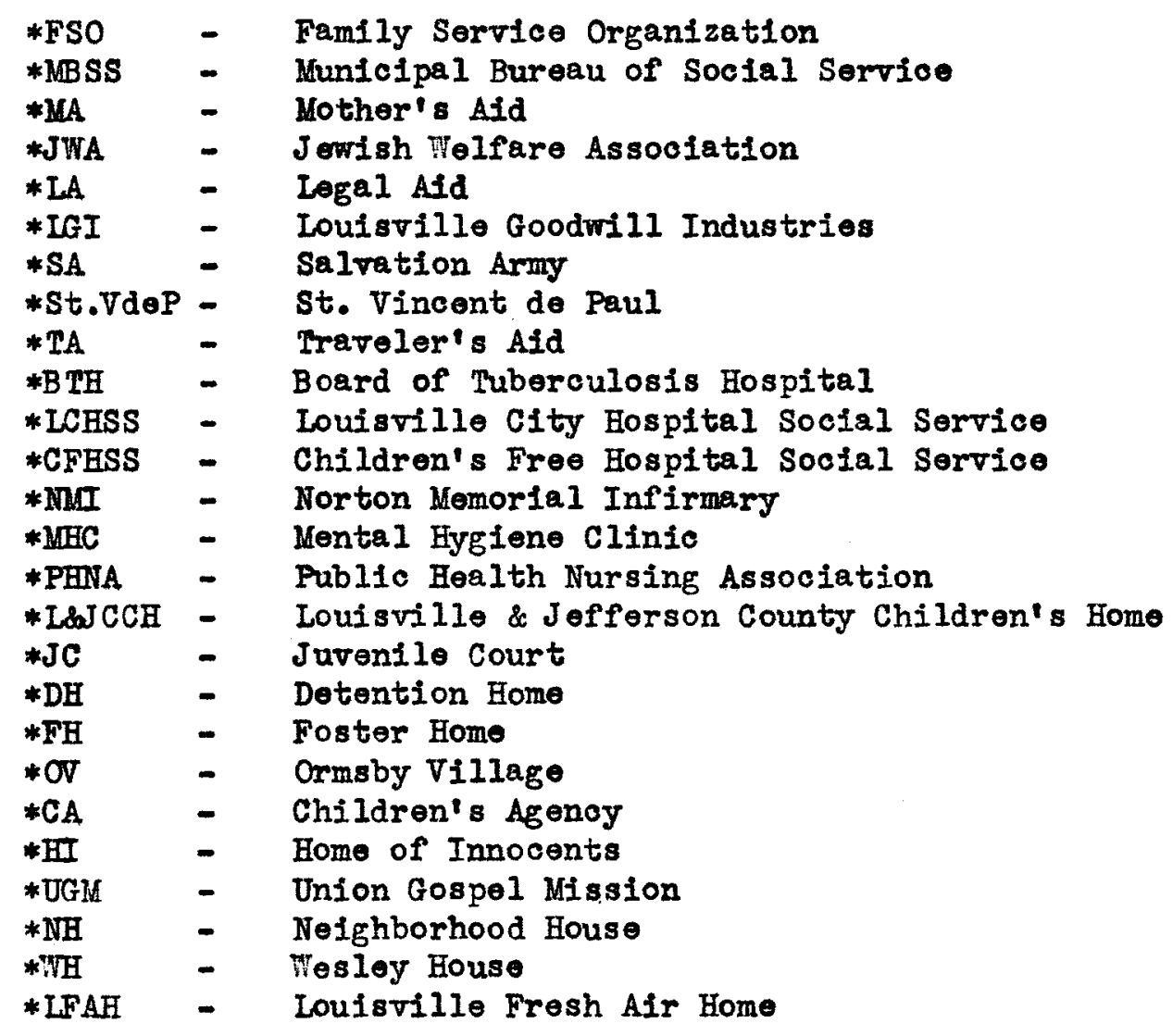


As a rule, at no time is more than one social agency active in a family. However, at different times many of these families had been known to more than one agency. This indicates two things. First, the disorganization and deterioration of the family life to such an extent that the family needed outside help and second, that from time to time the problem changed and the family was referred to the agency whose function it was to care for that particular problom. The following table shows the number of families in the George W. Morris Sohool District inown to one or more social agencies. 
TABLE XVI

THE NUMBER OF FAMIIIES REPRESENTED IN THE GEORGE W. MORRIS SCHOOL KNOWN TO ONE OR MORE SOCIAL AG ENCIES

\begin{tabular}{llllllllllllll}
\hline \hline $\begin{array}{l}\text { Number } \\
\text { Agencies }\end{array}$ & 1 & 2 & 3 & 4 & 5 & 6 & 7 & 8 & 9 & 10 & 11 & Total \\
\hline $\begin{array}{l}\text { Number } \\
\text { Families }\end{array}$ & 61 & 60 & 45 & 48 & 26 & 29 & 26 & 14 & 7 & 4 & 1 & 321 \\
\hline
\end{tabular}

of the 394 families in the George W. Morris School, 321 families

or 81.4 per cent have been known to one or more agencies.

A study of Table XV and Table XVI shows, first, that many families were known to more than one agency in each classification, as well as in different classifications; second, the large number of families known to family welfare and relief agencies; third, the relatively small number known to group agencies; 7 fourth, the number of families who had applied to the family welfare and relief agencies but for some reason their application was not accepted. All of these factors, especially two and three, indicate the heavy burden other than educational that is placed upon the school.

\footnotetext{
7 The Neighborhood House and Wesley House, both Community Centers, register with the Social Service Bxchange only those families in which the children present a problem to the settlement.
} 
In a district as crowded, as congested as the Morris School district one of the factors which should be considered is the type dwellings in which the children live. The following table gives an analysis of this. 
THE TYPE DWELLINGS IN WHICH THE FAMILIES REPRESENTED IN THE GEORGE W. MORRIS SCHOOL LIVED, SHOWING THE NUMBER OF FAMILIES AND THE NUMBER OF CHILDREN WHO LIVED IN EACH TYPE

\begin{tabular}{lcc}
\hline Type Dwelling & Number Families & Number Children \\
\hline One family house & 32 & 50 \\
Home connected with business & 22 & 34 \\
Apartment (furnished) & 5 & 6 \\
Apartment (unfurnished) & 89 & 133 \\
$\begin{array}{l}\text { Automobile trailer } \\
\text { Rooming house }\end{array}$ & 1 & 1 \\
$\begin{array}{l}\text { Tenements converted from } \\
\text { old business houses }\end{array}$ & 154 & 209 \\
$\begin{array}{l}\text { Tenements converted from } \\
\text { old houses }\end{array}$ & 55 & 93 \\
\hline \begin{tabular}{l} 
Totals \\
\hline \hline
\end{tabular}
\end{tabular}


of the 394 families 32 or 8.1 per cent lived in one family dwellings; 22 or 5.8 per cent lived in homes connected with the business of the family; 94 families or 23.8 per cent lived in apartments; 154 families or 39 per cent lived in rooming houses; 55 families or 13.9 per cent lived in tenements converted from old business houses; 36 families or 9.1 per cent lived in tenements converted from old houses; and 1 family or .2 per cent lived in an automobile trailer.

Many of the one family houses were run down and delapidated. The apartments were not all in regular apartment buildings but were old houses which had been converted into very habitable dwellings. of the 580 children 50 or 8.6 per cent lived in one family houses; 34 children or 5.8 per cent lived in homes connected with the family business, 139 or 23.9 per cent lived in apartments, 209 children or 36 per cent lived in rooming houses; 147 children or 25.3 per cont lived in tenements and 1 child or .1 por cont lived in a trailor.

No attempt was made to study the dwellings from which the children come by ownership and tenancy. In Dr. Kutek's study it was shown that for the four census tracts which are included in or border the Morris School district 9.8 per cent of the dwellings are owned by occupants and 91.2 per cent are rented.

While the above studies were made for the school year 1938-39, they give a good picture of the conditions existing in the neighborhood 
not only for that year but for a period of years. So it may be concluded from these findings that the problem of relief; the problem of the spread of contagion; the problem of care of children who are sick either at home or at school; the problem of the supervision of children during out of school time; the necessity of working with social agencies in order to help sol these difficulties; plus the problems of behevior, maladjustments growing out of inadequate incomes, of living under crowded conditions, of living in broken homes, of having the mother out of the home for the majority of the day, present to the school many and raried questions. How the school, through its personnel work, attempts to meet and treat the problems will be taken up in a later division of this thesis. 
PART II

THE GEORGE W. MORRIS SCHOOL 


\section{CHAPTER I}

THE GEORGE W. MORRIS SCHOOL BUILDING 


\section{CHAPTER I}

\section{THE GEORGE T. MORRIS SCHOOL BUILDING}

In a thesis which deals with the question of how the life of a given oommity is reflected in the problems presented to the school and how the school endeavors to meet these problems a study of the school, as well as a study of the community, is necessary. In this, school should not only mean the building itself but it should include certain phases of the school set up. These phases are the school staff, its training and experience and its philosophy toward the work of the school, the pupil enrollment, how many children attend, the nationality of the pupils, the mobility of the enrollment, and the educational status of the children. These phases of school life make up the environment of the school. In dealing with problems of pupil personnel it is equally as important to have a knowledge of the environment into which a child is to be fitted as it is to know of the environment from which he comes. Therefore, in the solving of the problems of the individual children all of these elements may enter and for the visiting teacher to be able to help solve the problems referred to her she must have a knowledge and an understanding not only of the out of school life of the child but of the school life to which he belongs.

So the first consideration in this part of this thesis will be a study of the George W. Norris School building. 
The George W. Morris School, an elementary school of six grades, stands on the south-oast corner of Floyd and Chestnut Streets in Louisville, Kentucky. The work of building this school was begun in the Fall of 1852 and the school was opened in July, 1853.1 The school was a two story building with eight class rooms. A large cloak room opened into each class room.2 In 1893, because of the crowded conditions due to the increase of the foreign element, a third floor was added. 3 A heating and a ventilating system were also installed. 4

There has been little change in the physical structure of the Morris School in the eighty-six years that it has housed the school children of this neighborhood. It now consists of three stories containing eighteen class rooms, a principal's office, a lunch room, a teacher's rest room and a stock room. Now there are no cloak rooms. The partitions between the cloak rooms and the class rooms were evidently taken down in order to enlarge the class rooms. The toilet facilities for the children are in the basement.

The class rooms are all approximately the same size, twenty-six by twenty-six feet square. Thirteen are in use for regular class room work. Of the five unoccupled rooms, one of the two on the first floor

1 Minutes of the Board of Education, Public Schools of Louisville, July 6,1853 .

2 Louisville Post, September 25, 1922.

3 Minutes of the Board of Education, Public Schools of Louisville,

4 Ibid, August 7, 1893. 
is used by the speech defect teacher and the special music teacher, the other for a lunch room; the one on the second floor is used by the doctor and nurse, for the monthly weighing of the ohildren, and for the children who take piano lessons but who have no pianos in their homes to practice; and the two on the third floor are used for club work and special group work. In the class rooms there are no closets for supplies. Cabinets have been placed in each of these rooms to meet this need. In all of the rooms except in the Kindergarten the children's desks are placed in rows and are sorewed to the floor. Since there are no cloak rooms the children's wraps are hung on hooks in the halls. This often causes confusion, particularly among the younger children because the wraps are knocked down and wen rehung are placed on different hooks and the children cannot find them. Besides this, the sohool has been faced with the problem of passersby coming into the building and taking the ohildren's wraps.

The size of the principal's office is about ten by twenty foet. Since the visiting teacher has no office she works either in this office or in a corner of the hall. The clerk has her desk in the principal's office. The files containing the cumulative records of the children and the current card index, as well as the cabinet containing the materials for first aid are here also. Besides this, the only telephone in the school is here. Because the office is in such constant use there is little opportunity for privacy. Occasionally, it is possible to 
find privacy in one of the five rooms that are not used for regular class room work. This lack of privacy makes either interviewing with mothers or children or conferences between principal, teachers and visiting teacher very difficult.

The school lunch room is on the first floor. Because of its size it cannot accomodate many children at a time. Therefore, the lunch schedule has to begin early and consequently many of the children have lunch earlier in the day than is desirable.

The lot on which the school is built is two hundred by two hundred and twenty-five feet. All of this except the space occupled by the school building and a space, eighteen by fifty feet, which has been converted into a flower garden, is used for the playground. The playground is paved with bricks and there is no playground equipment.. Since there is no gymnasium, in inclement weather the children have to stay in their class rooms or in the halls during play poriods.

The school is situated on a busy down town corner where the traffic is quite heary. The street noises combined with the noise of the children at play during recess periods creates a noise that at times is both confusing and disturbing to the children at work. The inadequacies of the building, as well as the lack of playground space and equipment present problems to the school staff which take ingenuity, good humor, tact and patience to meet and then often these problems are either only partially solved or not solved 
at all. For example, as has been pointed out, the children have to hang their wraps in the hall and often confusion and waste of time ensue because of lost wraps. In an endervor to overeome this, some of the teachers attempt to teach the children to put their gloves and caps in their coat pockets or coat sleoves, to use the same hooks each day on which to hang their wraps and to get the mothers to sew name tapes inside the wraps. Yet, with the best of planning and of organization, because the wraps have to be hung in the hall and are knocked down by pessersby, left on the floor or hung on different hooks, confusion and waste of time follow.

The question may be raised, that in a community where so many of the children come from orowded homes, where they are so often surrounded by confusion and disorganization should not a school that is modern both in its building and equipment, a school that has adequate playspace and play equipment both in and out of doors be provided for these children? 
CHAPTER II

THE SCHOOL STAFF OF THE GEORGE $W$. MORRIS SCHOOL 
THE SCHOOL STAFF OF THE GEORGE W. MORRIS SCHOOI

The class room teacher is the focal point of every class room situation. It is around her leadership and guidance or lack of either that the activity of the class room centers. She should not only have educational training and teaching experience but she should have a knowledge of the kind of neighborhood in which the children which she teaches live, as well as an interest in and a desire to help solve the problems which these particular children present to the school. Bvery help, every aid possible should be given her. At the George W. Morris Sohool the educational qualifications and the teaching experience of the staff are highly important but, at least, of equal importance is the attitude of the staff toward its work. If the principal and teachers did not recognize the problems the ohildren present, refer them to the visiting teacher and cooperate in helping work out these problems much of the effectiveness of the work of the visiting teacher would be lost. Besides showing the oduoational training and teaching experience of the teaching staff it is the purpose of this chapter to show how this insight and cooperation have been gained.

The staff of the George W. Morris School consists of a principal, one Kindergarten teacher, twelve regular class room teachers, a visiting teacher and a school nurse. The visiting teacher is assigned to the school every day for half a day. The school nurse works under the direction of the City Board of Health and has no regular schedule at 
the school. The school also has the services of a clerk, an engineer, and a janitor. The lunch room is managed under the auspices of the Council of Jewish Women. The work of the lunch room is done by one paid worker, assisted by rolunteer workers from the Council.

The educational training and teaching experience of the principal and teachers is shown in the following table. 
TABIE XVIII

THE EDUCATIONAL TRAINING AND TEACHING EXPERIENCE OF THE PRINCIPAL AND TEACHERS OF THE GBORGE $\%$. MORRIS SCHOOL

\begin{tabular}{|c|c|c|c|}
\hline Grade & $\begin{array}{l}\text { Educational } \\
\text { Training }\end{array}$ & $\begin{array}{l}\text { Number Years } \\
\text { Total Number } \\
\text { Years }\end{array}$ & $\begin{array}{l}\text { Teaching Experience } \\
\text { Number of Years at } \\
\text { Morris School }\end{array}$ \\
\hline Principal & $\mathbf{A B}$ & 46 & 10 \\
\hline Kindergarten & $A B$ & 14 & 12 \\
\hline IB & $\mathrm{AB}$ & 34 & 6 \\
\hline $1 \mathrm{~A}$ & BS in Education & 9 & 1 \\
\hline 2B & $A B$ & 10 & 10 \\
\hline 2A & $A B$ & 9 & 3 \\
\hline $3 \mathrm{~B} *$ & $A B$ & 5 & 1 \\
\hline $3 \mathrm{~A}$ & $A B$ & 18 & 18 \\
\hline $4 \mathrm{~B}$ & BS in Education & 4 & 2 \\
\hline $4 \mathrm{~A}$ & $\mathrm{AB}$ & 3 & 3 \\
\hline $5 B-$ & Normal School & 5 & 5 \\
\hline $5 \mathrm{~A}$ & Normal School & 35 & 10 \\
\hline $6 B$ & $\mathbf{A B}$ & 19 & 6 \\
\hline $6 A *$ & BS in Education & 19 & 12 \\
\hline
\end{tabular}

* Working toward Master's Degreo.

- Working toward Bachelor of Arts Degre日. 
It will be noted that the principal and all the teachers except two have their first degree and that one of the two who has only a Normal School degree is working toward a Bachelor of Arts degree. It will also be noted that two of the teachers are working toward a Master's degree.

The visiting teacher has a Bachelor of Science degree in Education and is working toward her Master's degree. She has had seven years experience as a Kindergarten teacher and twelve years experience as a visiting teacher. Four years of her Kindergarten teaching was done in this school and she has been here as visiting teacher for twelve years.

As has been pointed out, the educational qualifications and teaching experience of the staff of the George $W$. Morris School are highly important but of equal importance is the attitude of the staff toward attacking and solving the problems of the children of this particular school. This insight and cooperation has been gradually developed in the school by the principal and visiting teacher quietly but persistently educating the teachers to an appreciation of this neod. As this understanding was developed in the teachers they in turn helped educate the new teachers who were assigned to the school from time to time.

It may be asked, how was this accomplished? Besides faculty meetings, conferences with the principal and teachers and the use of case studies, several informal methods were used to help develop this attitude. 
It is the habit in this school for the teachers to gather in the principal's office each moming for a short period before the opening of school. Here the principal has the opportunity to listen to the teachers tell of the problems their children present and also she has the opportunity to lead the teachers to exchange their experiences in handling the problems of the various children. She in turn can, in an informal but very effective way, have the teachers recognize the problems of these children. As time permits, the visiting teacher joins this group and she contributes to the discussion an interpretation of the experiences she has had in her work in the district.

The visiting teacher has made several other contributions toward this kind of education. At the beginning of each semester she has gone over the class enrollment with any of the new teachers in the school. In doing this she has had the opportunity not only to tell of the children of this particular grade but she has had the chance of giving the new teacher an insight into the kind of district in which the school is located. Occasionally the visiting teacher takes a teacher visiting with her. The visiting teacher also makes a practice of, as often as possible, stopping in the school lunch room and talking with the teachers. Here she tells them human interest stories which she gathers in her days work. Her objective in this is, to try and help the teachers get a picture of the district and to realize some of the problems which face the people of this district in their every day lives. 
At the present time this desire to work together for the good of the children prevails and may be illustrated in the following incident.

A new teacher was assigned to the school and had charge of one of the lower grades. One morning at the first recess the door of the principal's office was opened, a teacher who appeared quite disturbed entered and closed the door. The principal and visiting teacher were both in the office.

The teacher said, "We don't like that new teacher who has been sent here."

"Why?" asked the principal.

"Because," said the teacher, "She doesn't understand Johnny Jones. She blames him for his behavior and doesn't try to help him." Johnny Jones was a neglected waif who was quite a school problem. He had been in the school a year and the interest of the teachers in the child had been aroused and it was felt by the school that some headway had been made with Johnny.

The visiting teacher joined in with, "We have a job before us. We will have to educate Miss -.- toward our way of thinking."

And so it was planned that the teachers, led by this particular one, should begin, whenever the occasion permitted, to tell the new teacher of the work of the school, the prineipal would find the opportunity of talking with her and the visiting teacher would invite her to go visiting with her in the district. By means of this bit of 
cooperative education the interest of the new teacher was not only aroused in the welfare of Johnny Jones but also in the problems of her entire class.

Another contribution the visiting teacher makes toward the education of the teachers at the Morris School concerning the problems of the school is to help them recognize problems of withdraw, timid, shy, backward children. Sometimes when she is in a home a parent will tell her of such a child's problem, or perhaps on the playground, in the halls or when visiting a class room she observes such a child and in either case she calls the attention of the teacher to this partiaular child. Then through studying that child, giving the teacher a picture of the child's background and working with the teacher and ohild the visiting teacher demonstrates how such a child can be helped. The teachers then in turn become more observant of the children under their charge.

In the Morris School because the children come from such underprivileged homes, because the teachers have so many obstacles such as low mentality of the pupils, lack of cooperation and understanding on the part of the parents, there is often little or no result to show for work that has been intelligently and patiently performed. Consequently, sometimes the teachers become discouraged and disheartened. To help combat this feeling, the visiting toacher is constantly on the wateh for signs of improvement in the children or of expressions of appreciation in the homes and she always brings back a report of these to the principal 
and teachers. This not only helps the teachers maintain their morale but it helps to increase and maintain the interest they have in the children. Sometimes the visiting teacher receives criticism of the teachers from disgruntled parents. Often these criticisms are ungrounded and if they are the visiting teacher makes every effort to smooth out the situation without the teacher knowing of the criticism. Keeping from the class room teachers these trivial, inconsequental criticisms also helps maintain their morale. However, if the criticism seems valid the visiting teacher makes a report of it to the principal who in turn takes it up with the teacher. And so it is by these methods that the understanding, insight and cooperation of the teachers of the Morris School has been gained. It is not only the attitude of the principal, teachers and visiting teacher that is important but of every member of the school who comes in contact with the children. The spirit of cooperation, of accepting the problems of this school and working out these particular problems, of all worling together for the good of the child, prevails through the school, from principal to janitor. The feeling of contentment, of good will, of friendliness and of cheer is predominant. The principal, in the truest sense, is a counsellor and a guide to every member of her staff. Not only the teachers, but overy worker in the school exhibits a real interest in the lives of the children. An incident may best illustrate this. Every Christmas the engineer takes as his prerogative the privilege of decorating the first floor hall. The children have 
learned to expect, to look forward to, and to wait for this with eagerness and enjoyment.

Thus because of this attitude of interest, of willingness, of cooperation, of desire to lead the children to a higher level of living the sohool is ablo to accomplish much more for the children who come to It.than if this feeling did not prevail. It is desirablo that this level be maintained bocause without it little effective personnel work oan be accomplished. 


\section{CHAPTER III}

THE GEORGE W. MORRIS SCHOOL ENROLLMENT 
THE GEORGE $W$. MORRIS SCHOOL EINROLLMENT

It has been shown in a previous section of this thesis that

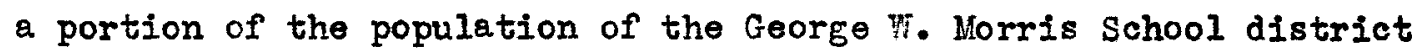
is composed of foreigners and also that the district has a high rato of mobility. Naturally, these conditions are reflected in the school and raise such questions as language difficulties of foreign ohildren and the problem of handling children from transient families so that they may become adjusted to the school as soon as possible. This chapter will first, demonstrate through an analysis of the school enrollment for the school year 1938-39, through a study of the new entries at the school during the school yoar 1933-34 showing from where they came and the number who returned the two following years, and an analysis of the length of time the children of the $6 \mathrm{~A}$ grades for February, 1939 and of June, 1939 attended the Morris School, the extent of these two problems; and second, this chapter will describe how the school attempts to meet these problems.

During the school year 1938-39 the Morris School had 608 children enrolled in the school. However, 28 of the children came from the Home of the Innocents, 1 and because they were not normally a part of the school neighborhood, and because as a rule they attended

1 Home of the Innocents, an Episcopal Home for the temporary care of children. 
the school for only a short period, some for only a few days, they were omitted from this study. Therefore, 580 children coming from 394 families were included in the study.

Most of the children who attend the Morris School come from homes of native born American parents. However, there is a foreign element in the school. In the past, this foreign element was much larger than it is now. For instance, there has been a decline in the number of foreign born children from 6.5 per cent in $1920^{2}$ to .3 per cent in 1939. There has also been a decline in the number of chlidren of foreign born parents from 35.6 per cent 3 in 1920 to 5.8 per cont in 1939.

The following table shows the number of foreign born children and the number of children of foreign born parents or grandparents attending the school during the school year 1938-30.

2 Files, George W. Morris School, Study made by liss Florence Kahlert then prinelpal of the school, October, 1920.

3 Ibid 
TABLE XIX

THE NUMBER OF FOREIGN BORN CHILDREN AND THE NUMBER OF CHILDREN OF FOREIGN BORN PARENTS OR GRANDPARENTS IN THE GEORGE W. MORRIS SCHOOL DURING THE SCHOOL YEAR 1938-39

\begin{tabular}{llll}
\hline Number & $\begin{array}{l}\text { Number } \\
\text { Children }\end{array}$ & $\begin{array}{l}\text { Number Children } \\
\text { Foreign Born }\end{array}$ & $\begin{array}{l}\text { Number Children With Foreign } \\
\text { Born Parents Or Grandparents }\end{array}$ \\
\hline 50 & $\begin{array}{l}\text { Both } \\
\text { Parents Father Mother Parents }\end{array}$ \\
\hline
\end{tabular}

As the above study shows that for the school year 1938-1939 there were only two foreign born children in the school. Both of these were from refugee German families.

In every instance, save one, of the foreign born parents, the husband and wife were of the same nationality. This exception was in the case of a Spaniard who married a native American. In every instance of foreign born grandparents, the husband and wife were of the same nationality.

In the families where both or one of the parents or the grandparents were forelgn born, they came from the following countries and had the following number of children in school. This is shown in table XX. 
TABIE XX

THE COUNTRIES FROM WHICH THE PARENTS OR GRANDPARENTS OF THE CHILDREN OF FOREIGN DESCENT IN THE GEORGE $W$. MORRIS SCHOOL CAME, SHOWING THE NUMBER OF FAMIIIES AND THE NUMBER OF CHILDREN

\begin{tabular}{|c|c|c|}
\hline Country & Number Families & Number Children \\
\hline \multicolumn{3}{|c|}{ Both Parents Foreign Born } \\
\hline Syria & 16 & 24 \\
\hline Germany & 3 & 4 \\
\hline Italy & 2 & 3 \\
\hline Russia & 1 & 1 \\
\hline Poland & 1 & 1 \\
\hline \multicolumn{3}{|c|}{ Father Foreign Born } \\
\hline Russia & 3 & 3 \\
\hline \multirow[t]{2}{*}{ Spain } & 1 & 2 \\
\hline & Mother Forelgn Born & \\
\hline Syria & 1 & 1 \\
\hline \multirow[t]{2}{*}{ Poland } & 1 & 1 \\
\hline & andparents Foreig & \\
\hline Syria & 10 & 16 \\
\hline Russia & 11 & 14 \\
\hline
\end{tabular}


This table shows that there is a predominance of children of Syrian descent in the school. Thirty-two per cent of the children of foreign descent had both parents born in Syria and 22.2 per cent of the children had both grandparents born in Syria.

The decline in the number of foreign born children from 6.5 per cent in 1920 to .3 per cent in 1939 together with the decline in the number of children of foreign born parents from 35.6 per cent in 1920 to 5.8 per cent in 1939 indicates that the problem of children of foreign descent is not so great as it was formerly and also that it may be expected to grow less each year. It also indicates something of the mobility of the school population. While the foreign poople are retaining their businesses in this neighborhood they are moving their homes to other sections of the city.

This mobility of the sohool population is one of the major problems confronting the school. A study of the length of time the children have attended the school shows how great this problem is. of the 580 children enrolled in the school during the school year 1938-39 one hundred and ninety-four were new to the school. The others had attended anywhere from five months to seven years. This is shown in table XXI. 
TABLE XXI

LENGTH OF TIIE THE 580 CHILDREN ENROLLED IN THE GEORGE W. MORRIS SCHOOL DURING THE SCHOOL YEAR 1938-1939 HAVE BEEN IN ATTENDANCE IN THIS SCHOOL

5 months to 1 year

1 year to 2 years

2 years to 3 years

3 years to 4 years

4 yoars to 5 years

5 years to 6 years

6 years to 7 years

7 years to 8 yoars

8 years

0

New entries during School year 1938-39 
Sixty-one of the children mentioned in Table XXI did not attend for consecutive periods. Some entered and left the school as many as seren times.

This table shows that 194 or 33.4 per cent of the children were new to the school. It also shows that 133 or 23 per cent of the children had been in the school one to two years which was the longest period that the greatest number of children had attended the school. Including the two years attendance in Kindergarten, it is possible for a child to attend the school eight years. None of the children did this. Only 3 or .5 per cent of the children attended for seven years. The mobility of the school population is also shown in an analysis of the number of years attendance at the Morris School of the children who completed the 6A grade in February, 1939 and in June 1939. In the February class there were thirty-three children enrolled. One left school before completing the grade and two were failures, leaving twenty-nine children who were promoted to junior high school. In the June class there were thirty-five children enrolled and six left the school before completing the grade leaving twenty-nine who were promoted to junior high school. The following table shows the number of years attendance of the children who completed the $6 \mathrm{~A}$ grades. 
THE NUMBER OF YEARS THE CHIIDREN OF THE 6A GRADES OF FEBRUARY, 1939 AND OF JUNE, 1939 ATTENDED THE GEORGE W. MORRIS SCHOOL

\begin{tabular}{|c|c|c|}
\hline \multirow{2}{*}{$\begin{array}{l}\text { Length of Time } \\
\text { In Attendance }\end{array}$} & 6A Class February, 1939 & $6 \mathrm{~A}$ Class June, 1939 \\
\hline & Number children & Number children \\
\hline 5 months to 1 year & 3 & 1 \\
\hline 1 year to 2 years & 7 & 10 \\
\hline 2 years to 3 years & 4 & 3 \\
\hline 3 years to 4 years & 6 & 2 \\
\hline 4 years to 5 years & 0 & 2 \\
\hline 5 years to 6 years & 3 & 2 \\
\hline 6 years to 7 years & 3 & 9 \\
\hline 7 years to 8 years & 3 & 0 \\
\hline 8 years & 0 & 0 \\
\hline Total & 29 & 29 \\
\hline
\end{tabular}


Seven children in the February class and three in the January class did not attend for consecutive periods. Some entered and left the school as many as five times. This table shows the same thing as Table XXI namely, that the greatest number of children spent only one to two years in school.

The mobility of the school population is also shown in a study that was made during the school years 1933-1934, 1934-1935 and 1935-1936. This study was made primarily to analyse the attendance of the new children in the school but it shows from where the new children came and how few of them remained in the school for any length of time. This is shown in the following table. 
THE NEW ENTRIES AT THE GEORGE W. MORRIS SCHOOL FOR THE SCHOOL YEAR 1933-1934 SHOWING FROM WHERE THEY CAME AND THE NUMBER WHO RETURNED TO THE SCHOOL DURTNG THE TWO FOLLOWING YEARS

\begin{tabular}{|c|c|c|c|}
\hline Children Came From & $\begin{array}{c}\text { Number Child ren } \\
1933-34\end{array}$ & $\begin{array}{c}\text { Number Children } \\
\text { 1934-35 }\end{array}$ & $\begin{array}{c}\text { Number Children } \\
1935-36\end{array}$ \\
\hline $\begin{array}{l}\text { Other Public School } \\
\text { In Louisville }\end{array}$ & 133 & 46 & 14 \\
\hline $\begin{array}{l}\text { Large City Schools } \\
\text { Than Loufsvillo }\end{array}$ & 24 & 7 & 1 \\
\hline Country Schools & 41 & 9 & 1 \\
\hline Parochial Schools & 6 & 15 & 7 \\
\hline $\begin{array}{l}\text { First Entrance Into } \\
\text { School }\end{array}$ & 29 & 5 & 2 \\
\hline Total & 233 & 82 & 25 \\
\hline
\end{tabular}


This table shows that of the 233 new ohildren who entered the Morris School during the school year $1933-34$ only 82 or 35.1 per cent returned the next year and only 25 or 10.7 per cont returned the third yoar.

These studies indioate that the Morris School is faced with certain definite problems. The school recognizes these problems and attempts to, at least, solio a portion of them. What these problems are and how the school attempts to meet them is shown in the following discussion.

1. Although the children from the Home of the Innooents were not included in the study, the problem they present to the school should not be mitigated. The fact that these ohildren are placed in the Home of the Innooents is ovideneo that there is some difficulty in their respeotive homes. Coming from such homes they are placed in two entirely new situations, the Home of the Innocents and the school and this frequently creates confusion in minds that are already confused. Although these children are not in school for any length of time and the school has little opportunity to do an intensive piece of case work, if need be, there are certain things the Home of the Innocents and the school working together can do. In the first place, the worker at the Home of the Innocents is careful not to send a child whom the feels is too disturbed, immediately to school. She helps him become adjusted to the home first. Then all children who enter the school from this institution are brought to the school by one of the workers. The school in turn receives the 
ohildren in a pleasant, friendly manner. Often the visiting teacher takes the children to the class room and introduces the child to the teacher. Othervise the principal or elerk and sometimes the worker from the home performs this duty. The children are in turn received in the same friendly, cordial manner by the teacher.

2. As a group, the children of foreign descent present the problem of language difficulties to the school. The individual teachers, as they can, help these children overcome these difficulties but there is no planned program in the school to meet this need.

3. The high rate of mobility of the sohool of not only accaunting for these children but of endeavoring to help these children become adjusted as soon as possible so that they may get the maximum help from the school in the short time they are under its care. How the sohool keops account of the transient element will be shown in Part III. The school tries to help these new children feel wanted, to feel a part of the school by giving them a cordial welcome when they first come to the school to register. If a parent accompanies a child, the prinoipal or visiting teacher, when sho is at the school, talxs with him, telling him something of the activities of the school. As a rule the ohildren are triken to the class room by the principal, visiting teaoher or clerk and here receives a frlendly wolcome from the teacher in charge. The class room teacher usually assigns some one to look after the new comor. Books and school supplies are issued as soon as possible. It would be highly advantageous if the visiting teacher had the time to make a 
friendly call into the home of all the new children when they first enter school. She could through this give to the class room teachers a picture of the family background of these children and this would be a great aid to the teacher in helping the children make adjustments.

4. A problem which grows out of the three above mentioned is the danger of the school giving so much time to the foreign and transient children that it deprives children who have been a part of the school for a longer period, of time and thought that is due them. This is a problem which the principal and visiting teacher are conscious of and which the principal is always cautioning the teachers to guard against and which the visiting teacher, through a constant analysis of hor own work attempts to keep herself from doing. 


\section{CHAPTER IV}

THE EDUCATIONAL STATUS OF THE PUPIIS

OF THE GEORGE W. MORRIS SCHOOL 


\section{CHAPTER IV}

\section{THE EDUCATIONAL STATUS OF THE PUPIIS}

OF THE GEORGE W. MORRIS SCHOOL

It has been shown that in the Morris School district there is a foreign element; the economic status of the families as a whole is low; the majority of children live in either rooming houses or tenements; there is a large urban element of the lower economic class; there is a high rate of mobility; and that there is a self evident lack of cultural beckground. Therefore, it is to be expected that the school is faced with the problems of low mentality, retardation, and all types of scholastic diffioulties. Something of the extent of these problems will be shown in this chapter through age grade distribution studies, through grade progress studies and through achievenent studies of the children of the Morris School in comparison With the children of the white elementary schools of the Public School System of Loulsville. In dealing with the problems of the individual children it is advaniageous for the visiting teacher not only to know of the mental ability, the retardation, the scholastic difficulties of the individual child but she should have a concept of the educational status of the entire school. She is then better equipped in her work of trying to adjust the individual child to the situation. 
Ph1lip A. Boyer says,

Practically every aspect of pupil personnel, guidance, and counseling has some immediate relation to the more restricted area designated as school progress. This term connotes the effectivemess of the educational experiences centered more or less formally in the school as a unique institution, and also of the school in its relations with the educational aspects of other social institutions. Since the initial shock of realizing the great waste through retardation and pupil failure, measures of age-grade status have constituted one of the means for evaluating the general efficiency of the organisation and operation of schools. There is, however, no evidence of increasing uniformity in the procedure for making age-grade and age-grade progress studies. I

Thus, the age-grade status of the pupils of the Morris School in comparison with the pupils of the white elementary sohools of the Louisville public chool system is one way of evaluating the educational status of the school. The age-grade study was made by the Bureau of Research of the Louisville publio school system, March 15, 1939. A child considered at his grade level must enter school at the age of six years chronologically and make normal progress from then on. This comparative study is shown in Table XXIV.

1 Boyer, Philip A.," School Progress," Review of Educational Research, 9:168, April, 1939. 
AGE GRADE IISTRTBUTION KARCH 15, 1939 SHOWING THE PER CENT OF PUPILS OF THE GEORGE W. MORRIS SCHOOL WHO WERE UNDERAGE, YORMAL AGE AND OVERAGE COMPARED WITH THE PER CENT OF PUPILS IN THE WHITE ELEMENTARY SCHOOLS OF THE IOUISVILLE PUBLIC SCHOOL SYSTEM UNDERAGE, NORMAL AGE AND OVERAGEI

\begin{tabular}{|c|c|c|c|c|c|c|}
\hline \multirow[b]{3}{*}{ Grade } & \multicolumn{3}{|c|}{$\begin{array}{l}\text { White Elementary Schools Louisville } \\
\text { Public School System }\end{array}$} & \multicolumn{3}{|c|}{ George W. Morris School } \\
\hline & \multicolumn{3}{|c|}{ Number } & \multicolumn{2}{|c|}{ Number } & \multirow[b]{2}{*}{$\begin{array}{l}\text { Over- } \\
\text { age }\end{array}$} \\
\hline & $\begin{array}{l}\text { Under- } \\
\text { age }\end{array}$ & $\begin{array}{l}\text { Normal } \\
\text { age }\end{array}$ & $\begin{array}{l}\text { Orer- } \\
\text { age }\end{array}$ & $\begin{array}{l}\text { Under- } \\
\text { age }\end{array}$ & $\begin{array}{l}\text { Normal } \\
\text { age }\end{array}$ & \\
\hline$I B$ & 13.0 & 74.9 & 12.1 & 10.8 & 67.5 & 21.7 \\
\hline $1 A$ & 22.5 & 63.5 & 14.0 & 16.0 & 74.0 & 10.0 \\
\hline $2 \mathrm{~B}$ & 10.2 & 67.1 & 22.7 & 9.4 & 56.3 & 34.3 \\
\hline $2 \mathrm{~A}$ & 28.3 & 62.4 & 19.3 & 11.5 & 40.4 & 48.1 \\
\hline 3B & 9.9 & 61.3 & 28.8 & & 42.1 & 57.9 \\
\hline $3 A$ & 18.5 & 60.6 & 20.9 & 20.0 & 55.6 & 24.4 \\
\hline $4 \mathrm{~B}$ & 22.5 & 60.0 & 27.5 & 5.0 & 70.0 & 25.0 \\
\hline $4 A$ & 18.8 & 55.7 & 25.5 & 26.3 & 33.8 & 39.9 \\
\hline $5 B$ & 12.6 & 57.2 & 30.2 & 3.4 & 41.4 & 55.2 \\
\hline $5 \mathrm{~A}$ & 19.5 & 54.4 & 26.1 & 10.2 & 46.9 & 42.9 \\
\hline $6 \mathrm{~B}$ & 12.5 & 56.3 & 31.2 & 9.5 & 40.5 & 50.0 \\
\hline $6 \mathrm{~A}$ & 19.7 & 56.2 & 24.1 & 18.4 & 44.7 & 36.9 \\
\hline $\begin{array}{l}\text { Average } \\
\text { Score }\end{array}$ & 16.6 & 60.3 & 23.1 & 12.9 & 51.2 & 35.9 \\
\hline
\end{tabular}

1 Age-grade Records, March, 1939 Files, Bureau of Research, Board of Education, Loui svilie, Rentuoky. 
In the Louisville public school system there is a chronological age requirement for entrance intc the $1 B$ grado. If a child is six years of age chronologically by the first of December he may enter the $1 \mathrm{~B}$ grade the preceding September. If he is six years of age chronologicially by the first of April he may enter the IB the preceding January. This in a measure accounts for the children underage for their grade level since the study was based on a child being six years of age chronologically when he entered the $1 B$ grade.

A comparison of the Morris School with the white elementary schools of the Louisville public school system in age-grade progress shows that for the school year 1938-39 the Morris School had 2.2 per cent fewer children underage and 9.6 per cent more children overage than the white elementary schools of the Louisville public school system. This indicates (1) that probably all of the children in the Morris school district who may enter the $1 B$ grade are not doing so, (2) that since the law does not require a child to enter school until he is seven years old chronologically, some children of the Morris school district are not entering until then, and (3) that probably there are more failures in the $1 B$ grade of the Morris School than in the IB grades of the white elementary schools of the Louisville public school system. Table XXIV also shows that in the Morris School there are 9.1 per cont fower children of Normal age for their grade level and 12.8 per cent more children average for thejr grade level than in the white elementary schools of the Louisville public school system. 
This again indicates the amount of retardation in the school. An analysis of the age-grade distribution of the Morris school shows that while 67.5 per cent of the children were of normal age in the $1 B$ grade oniy 44.7 per cent were of normal age in the $6 \mathrm{~A}$ grade. This decrease of 22.8 per cent indicates retardation. Further analysis also shows that while only 21.7 per cent started in the $1 B$ grade overage, 36.9 per cent were overage in the $6 \mathrm{~A}$ grade. This increase of 15.2 per cent is another indication of the retardation in the school. Another way of evaluating the educational status of the Morris School is by comparing the grade progress of the children of this school with the grade-progress of the children of the white elementary schools of the Louisville public school system. Grade-progress statistics show the time talen by a pupil to reach a given grade level compared with the standard set up which in Louisville is promotion every five months. On the basis of grade progress pupils may be divided into three classifications:

(a) those who have made rapid progress

(b) those who have made normal progress

(c) those who have made slow progress

The grade-progress study does not show retardation. It makes no difference whether a child enters school at six, seven or eight years of age chronologically if he progresses every five months it is that he made normal progress. Table XXV shows a comparison of the gradeprogress of the children of the Morris School with the grade-progress of the children of the white elementary schools of the Louisville public school system. 
TABLE XXV

GRADE PROGRESS STUDY MARCH 15, 1939 SHOFING A COMPARISON OF THE DISTRIBUTION OF PUPILS OF

THE GEORGE W. MORRIS SCHOOI WI TH THE PUPILS OF

THE WHITE HLEMENTARY SCHOOLS OF THE LOUISVILLE

PUBLIC SCHOOL SYSTEM WHO SHOWED NORMAL PROGRESS

AND DEVIATION FROM NORMAI PROGRESS 1

\begin{tabular}{|c|c|c|c|c|c|c|}
\hline \multirow[b]{3}{*}{ Grade } & \multicolumn{3}{|c|}{$\begin{array}{l}\text { White Elementary School Louis ville } \\
\text { Public Sohool System }\end{array}$} & \multicolumn{2}{|c|}{ George W. Morris } & \multirow{2}{*}{$\frac{\text { School }}{18}$} \\
\hline & \multicolumn{3}{|c|}{ Per Cent of Pupils } & \multicolumn{2}{|c|}{ Per Cent of Pupils } & \\
\hline & Rapid & Normal & Slow & Rapid & Normal & Slom \\
\hline 18 & & 72.9 & 27.1 & & 75.7 & 24.3 \\
\hline IA & 0.1 & 80.8 & 19.1 & & 80.0 & 20.0 \\
\hline 2B & 1.7 & 51.8 & 46.5 & & 37.5 & 62.5 \\
\hline $2 A$ & 1.9 & 73.4 & 24.7 & 3.9 & 60.8 & 35.3 \\
\hline 3B & 1.3 & 50.2 & 48.5 & & 31.6 & 68.4 \\
\hline $3 \mathrm{~A}$ & 1.7 & 73.7 & 24.6 & & 75.7 & 24.3 \\
\hline $4 B$ & 2.5 & 47.3 & 50.2 & & 31.6 & 68.4 \\
\hline $4 A$ & 1.8 & 68.1 & 30.1 & 2.6 & 57.9 & 39.5 \\
\hline 5B & 3.4 & 48.2 & 48.4 & & 27.6 & 72.4 \\
\hline $5 \mathrm{~A}$ & 2.2 & 68.1 & 29.7 & 4.7 & 65.1 & 30.2 \\
\hline $6 B$ & 5.5 & 48.3 & 46.2 & & 58.5 & 41.5 \\
\hline $6 \mathrm{~A}$ & 3.5 & 72.0 & 24.5 & 2.7 & 64.9 & 32.4 \\
\hline $\begin{array}{l}\text { Average } \\
\text { Score }\end{array}$ & 2.1 & 65.3 & 32.6 & 1.4 & 59.4 & 39.2 \\
\hline
\end{tabular}

1 Normal Progress and Deviation from Normal Progress Studies, Maroh 1939 Files, Bureau of Researoh, Board of Education, Louisville, Kentucky 
Table XXV shows (1) that in normal grade progress the pupils of the Morris School are 5.9 per cont below the average for the pupils of the white elementary schools of the Louisville public school system, (2) that in slow grade progress the pupils of the Morris School are 6.6 per cent above the average for the pupils of the white elementary schools of the Louisville public school system, and (3) that in rapid grade progress the pupils of the Morris School are .7 per cent below the average for the pupils of the white elementary schools of the Louisville public school system. This study shows that the pupils of the Morris School are more retarded than the pupils of the white elementary schools of the Louisville public school system.

A third way of evaluating the educational status of the pupils of the Morris School is through an analysis of various group tests which at various times have been given to selected grades in the school system. It has been the practice for a number of years to give all of the $6 \mathrm{~A}$ grades in the city a group intelligence test and several achievement tests. The same tests were used for September, 1936, February, 1937, September, 1937 and February 1938, so the results of these tests may bo used to show the eduaational status of the $6 \mathrm{~A}$ pupils of the Morris School for these four terms and to compare their educational status with the $6 \mathrm{~A}$ pupils in the white elementary schools of the Louisville public school system. The tests used were the KuhlmanAnderson Group Intelligence Test, the Metropolitan Achievement Test. The results of these tests are shown in the following tables. 
MEDIANS FOR CHRONOLOGICAL AND MENTAL AGES, READING, 1 LANGUAGE USAGE, I ARI TEMETIC REASONIHG, 1 AND COMPUTATION GRADE 6A FOR THE GEORGE W. MORRIS SCHOOL COMPARED WITH THE STANDARD MEDIANS AND VITH THE MEDIANS FOR THE 6A GRADES OF THE PUBLIC SCHOOLS OF LOUI SVI LLE (WHITE) SEPTEMBBER, 1936

\begin{tabular}{|c|c|c|c|c|c|c|c|c|c|c|}
\hline \multirow[b]{2}{*}{ 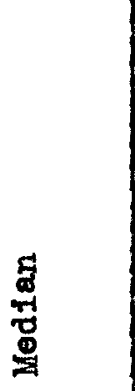 } & \multirow{2}{*}{ 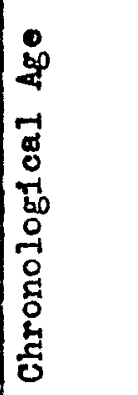 } & \multirow[b]{2}{*}{ 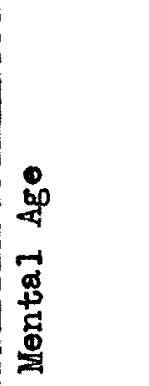 } & \multicolumn{2}{|c|}{ Reading } & \multicolumn{2}{|c|}{$\begin{array}{l}\text { Language } \\
\text { Usage }\end{array}$} & \multicolumn{2}{|c|}{$\begin{array}{l}\text { Arithmetic } \\
\text { Reasoning }\end{array}$} & \multicolumn{2}{|c|}{$\begin{array}{l}\text { Arithmetic } \\
\text { Commtation }\end{array}$} \\
\hline & & & $\mid \begin{array}{l}-1 \\
0 \\
0 \\
0 \\
0 \\
0 \\
0 \\
0 \\
0 \\
0\end{array}$ & 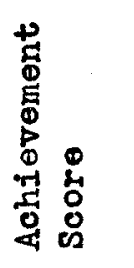 & 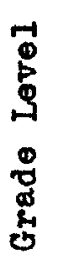 & 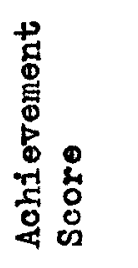 & 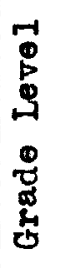 & 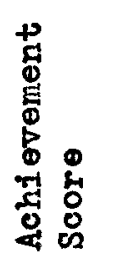 & \begin{tabular}{l}
-1 \\
0 \\
5 \\
9 \\
9 \\
0 \\
\multirow{2}{0}{} \\
0 \\
0
\end{tabular} & 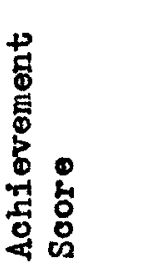 \\
\hline 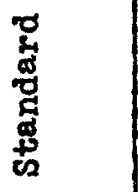 & $12-2$ & $12-2$ & $6 A$ & 12.2 & $6 \mathrm{~A}$ & 12.2 & $6 \mathrm{~A}$ & 12.2 & $6 \mathrm{~A}$ & 12.2 \\
\hline 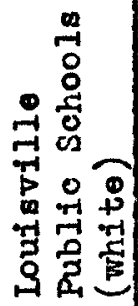 & $12-1$ & $11-2$ & $5 \mathrm{~A}$ & 11.1 & $6 \mathrm{~B}$ & 11.7 & $5 B$ & 10.9 & $5 \mathrm{~B}$ & 10.11 \\
\hline 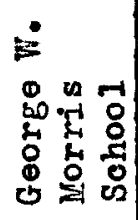 & $12-1$ & $10-6$ & $5 B$ & 10.9 & $5 \mathrm{~A}$ & 11.1 & $4 \mathrm{~A}$ & 10.1 & $5 \mathrm{~B}$ & 10.5 \\
\hline
\end{tabular}

1 Medians in terms of achievement scores and grade status, Metropolitan Achievement Tests. 
TABLE XXVII

MEDIANS FOR CHRONOLOGICAL AND MENTAL AGES, READING, ${ }^{1}$ IANGUAGE USAGE, ${ }^{1}$ ARITHMEIC REASONING, 1 AND CONPUTATION GRADE 6A FOR THE GFORGE W. MORRIS SCHOOL COIPARED 江TH THE STANDARD IEDIANS AND THE MEDIANS FOR TEE 6A GRADES OF THE PUBLIC SCHOOLS OF LOUISVIIIE (WHITE) FEBRUARY, 1937.

\begin{tabular}{|c|c|c|c|c|c|c|c|c|c|c|}
\hline \multirow[b]{2}{*}{ 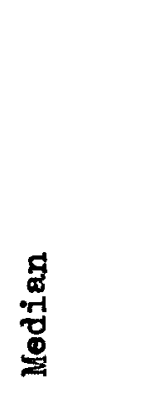 } & \multirow{2}{*}{ 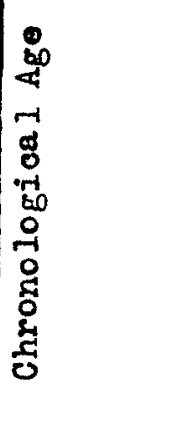 } & \multirow[b]{2}{*}{ 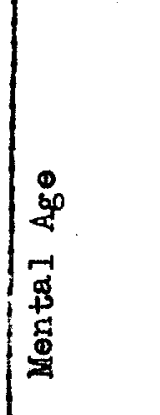 } & \multicolumn{2}{|c|}{ Reading } & \multicolumn{2}{|c|}{$\begin{array}{l}\text { Language } \\
\text { Usage }\end{array}$} & \multicolumn{2}{|c|}{$\begin{array}{l}\text { Arithmetic } \\
\text { Reasoning }\end{array}$} & \multicolumn{2}{|c|}{$\begin{array}{l}\text { Arithmetic } \\
\text { Computation }\end{array}$} \\
\hline & & & $\begin{array}{l}1 \\
0 \\
0 \\
9 \\
9 \\
0 \\
0 \\
0 \\
0 \\
0 \\
0\end{array}$ & 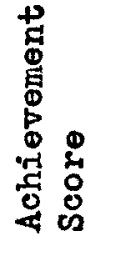 & $\mid \begin{array}{l}-1 \\
0 \\
0 \\
0 \\
0 \\
0 \\
0 \\
0 \\
0 \\
0 \\
0\end{array}$ & 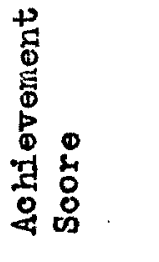 & 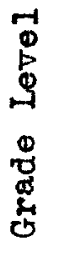 & 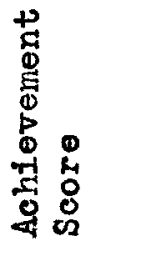 & 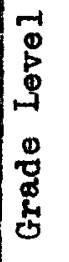 & 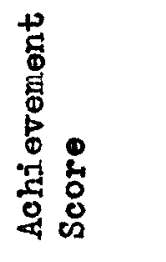 \\
\hline 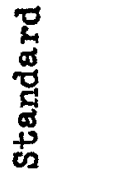 & $12-2$ & $12-2$ & $6 \mathrm{~A}$ & 12.2 & $6 \mathrm{~A}$ & 12.2 & $6 \mathrm{~A}$ & 12.2 & $6 \mathrm{~A}$ & 12.2 \\
\hline 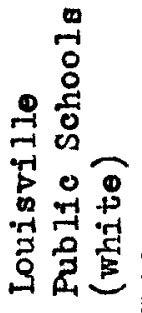 & $11-11$ & $11-10$ & $5 A$ & 11.0 & & 11.11 & $5 \mathrm{~A}$ & 11.1 & $5 \mathrm{~A}$ & 11.2 \\
\hline 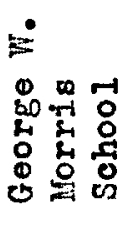 & $12-1$ & $11-8$ & $5 B$ & 10.8 & $6 \mathrm{~B}$ & 11.7 & $5 B$ & 10.9 & $5 B$ & 10.11 \\
\hline
\end{tabular}

1 Medians in terms of achievement scores and grade status, Metropolitan Achievement Tesis. 
MEDIANS FOR CHRONOLOGICAI AND MENTAL AGES READING, I LANGUAGE USAGE, 1 ART'RHMETIC REASONIJG 1 AND COMPUTATI ON GRADE 6A FOR THE GBORGE W. MORRIS SCHOOL CONPARED WI TH THE STANDARD JEDIANS AND WITH THE MEDIANS FOR THE 6A GRADES OF THE PUBLIC SCHOOIS OF LOUISVI LLE (WHITE) SEPTEMBER, 1937

\begin{tabular}{|c|c|c|c|c|c|c|c|c|c|}
\hline \multirow[b]{2}{*}{ 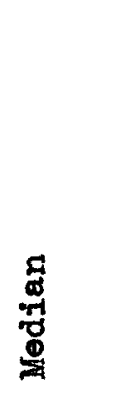 } & \multirow{2}{*}{ 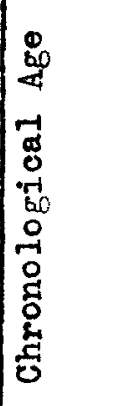 } & \multirow[b]{2}{*}{ 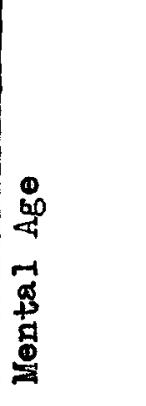 } & \multicolumn{2}{|c|}{ Reading } & \multicolumn{2}{|c|}{$\begin{array}{l}\text { Language } \\
\text { Usage }\end{array}$} & \multicolumn{2}{|c|}{$\begin{array}{l}\text { Arithmetic } \\
\text { Reasoning }\end{array}$} & $\begin{array}{l}\text { Arithmetic } \\
\text { Computatio }\end{array}$ \\
\hline & & & $\mid \begin{array}{l}-1 \\
0 \\
0 \\
0 \\
0 \\
0 \\
0 \\
0 \\
0 \\
0 \\
0\end{array}$ & 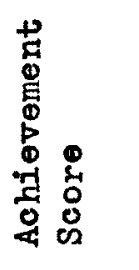 & 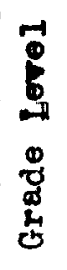 & 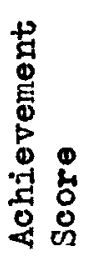 & $\begin{array}{l}0 \\
0 \\
0 \\
0 \\
0 \\
0 \\
0 \\
0 \\
0\end{array}$ & 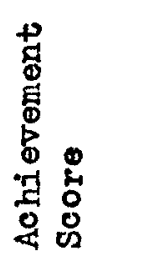 & 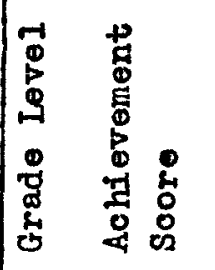 \\
\hline 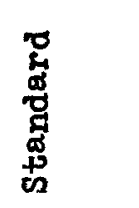 & $12-4$ & $12-4$ & $6 A$ & 12.4 & $6 \mathrm{~A}$ & 12.4 & $6 \mathrm{~A}$ & 12.4 & $6 \mathrm{~A} \quad 12.4$ \\
\hline 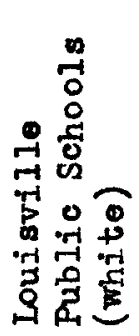 & $12-0$ & $11-5$ & $5 A$ & 11.6 & $6 B$ & 12.1 & $6 \mathrm{~B}$ & 11.10 & $5 \mathrm{~A} \quad 11.5$ \\
\hline 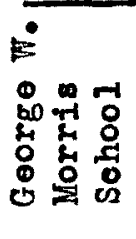 & $12-3$ & $11-7$ & $5 \mathrm{~A}$ & 11.6 & $4 \mathrm{~A}$ & 10.7 & $5 \mathrm{~A}$ & 11.5 & $5 B \quad 11.2$ \\
\hline
\end{tabular}

1 Medians in terms of achievement scores and grade status, Metropolitan Achievement Tests. 
MEDIANS FOR CHRONOLOGICAL AND MENTAL AGES, READING, 1 LANGUAGE USAGE, 1 ARITHMETIC REASONING, 1 AND COMPUTATION GRADE 6A FOR THE GEORGE W. MORRIS SCHOOL CONPARED WITE THE STANDARD IEDIANS AND VI TH THE MEDIANS FOR THE 6A GRADES OF THE PUBLIC SCHOOLS OF LOUISVILIE(WHITE) FEBRUARY, 1938

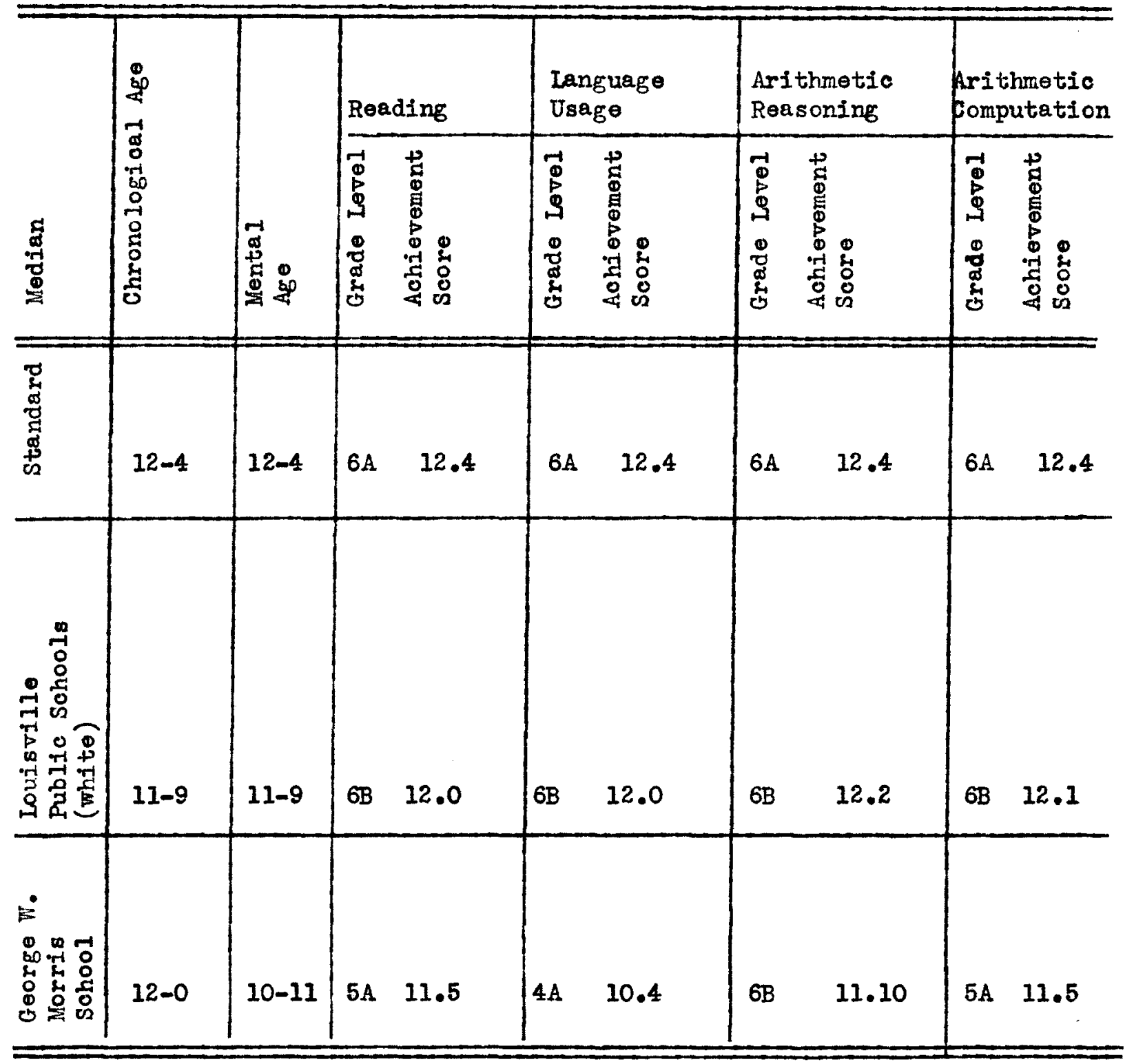

1 Medians in terms of achievement scores and grade status, Metropolitan Achievement Tests. 
An analysis of these four tables shows (1) that the $6 \mathrm{~A}$ pupils in the Morris School on the whole are deficient in accomplishment in all subjects included in the study; (2) the $6 \mathrm{~A}$ pupils in the Morris School for all four tests are not only below the standard medians but they are also below the medians for the $6 \mathrm{~A}$ pupils of the Louisville public schools (white) except in September, 1937 when the 6A pupils of the Morris School had the same median in reading achievement as the 6 A pupils of the Louisville public schools (white); (3) that although the median chronological age for the $6 \mathrm{~A}$ pupils of the Korris School of all four tests in only one to three months lower than the standard medians and two to three months higher than the medians for the $6 \mathrm{~A}$ pupils of the Louisville public schools, (white), the median mental age for the $6 \mathrm{~A}$ pupils of the Morris School at all four tests is from 6 months to 1 year and 5 months below the standard medians and for three of the tests is 2 to 10 months below the medians for the $6 \mathrm{~A}$ pupils of the Louisville public schools (white). In September, 1937 the median mental age for the $6 \mathrm{~A}$ pupils of the Morris School was two months higher than the median mental age of the $6 \mathrm{~A}$ pupils of the Louisville public schools (white).

Statistical data and tests results are not absolute measures of a schools accomplishment, but they are indicative of the general status of the school. The age-grade study, the grade-progress study and the achievement tests all show that the pupils of the Morris School are on the whole deficient in accomplishment in comparison with the pupils of the white elementary schools of the Louisville public 
school system.

Philip Boyer in his article on "School Progress" ma'es the following conclusions.

Research studies in the field of school progress showed recognition of the fact that nass progress can come only as detailed techniques are perfected for advancing the development of each pupil. Studies of school progress made their original contribution by disclosing failure and educational waste. It was in the recognition of this waste that personnel work, guidance, and counseling were born. Recent school progress studies have appropriated the techniques of guidance and counseling in their emphasis upon the unique qualities of each individual. General school progress is based on the best possible adjustment of each individual.2

An analysis of the above statistics raises the question of what kind of curriculum is planned for the pupils of the George $W$. Morris School. This school uses the text books chosen for the state at large and follows a course of study planned for all of the elementary schools in the city. No curriculum study has ever been made with the distinct purpose of meeting the needs of the pupils of this particular school.

Mr. Boyer's conclusion raises the question of the need of personnel work as an aid in helping solve these problems of scholasiic maladjustments. How these problems of maladjustments of the individual children of the George W. Morris School, whether they be scholastic, behavior or any of the many difficulties which children

\footnotetext{
2 Boyer, Philip A.,"School Progress", Review of Educational Research, 9:172, Apri1, 1939 .
} 
present to the school, are analysed and treated through its personnel work will be discussed and illustrated by case studies in the next section of this thesis. 
PART III

THE PERSONNEL WORK OF THE GEORGE W. MORRIS SCHOOL 
CEAPTER I

WHO DOES THE PERSONNEL WORK AT IHE GEORGE W. MORRIS SCHOOL? 


\section{CHAPTER I}

WHO DOES THE PERSONNEL WORK AT THE GEORGE W. MORRIS SCHOOL?

In the past thirty-five years, as the need for personnel work has been recognized and as the work has developed, there has come into the field a group of new workers trained especially for personnel work. Some of these workers are school nurses, counselors with various functions, guidance teachers and visiting teachers. At the present time in the Louisville public school system there are school nurses who work under the supervision of the City Board of Health, visiting teachers, health counselors and guidance teachers. In the junior and senior high schools the Board of Education employs for personnel work visiting teachers, health counselors and guidance teachers. In the elementary schools the only specialized personnel worker employed by the Board of Education is the visiting teacher.

The school nurses are assigned to all of the schools in the system. As has been pointed out, the school nurse works under the direction of the City Board of Health, Her duties are four-fold. 1

(1) work with pre-school children

(2) work with school children

(3) placarding communicable diseases

(4) work with pre-natal cases

1 Duties of the School Nurse, Files, City Health Department, City Hall, Louis ville, Kentucky, 1938 . 
The emphasis of her work is on physical well being. The nurse at the Morris School has under her charge three elementary schools in the publie sohool system and three elementary parochial schools. She has no set schedule for Visiting the Morris Sohool. She comes with the doctor when he makes physical examinations of the chifdren or when he gives various immunizations. After these examinations she does the follow up work recommended by the doctor. As her work permits she calls at the school and makes visits of a health nature that are requested of her by the prinoipal or Jisiting teacher.

Ruth Strang says the following regarding personnel work. According to the broad definition of personnel work, every teacher is a personnel worker in the sense that all his contacts with students are stimuli which influenoe their development in body, mind or character. 1

In this sense every one at the Morris School is a personnel worker. However, at the Morris School the personnel worly is a cooperative job. It is the cooperative work of the principal, the teachers and the visiting teacher. If the princlpal and the teachers did not have an understanding of, or an insight into children's behavior and an appreciation for the need of personnel work many of the problems concerning the children probably would never oome to the attention of the visiting teacher. Also, if the principal and the teachers were not interested in working out the children's problems,

1 Strang, Ruth, The Role of the Teacher in Personnel Work, p. 27. 
the work of the visiting teacher would be of little effect. And so, the visiting teacher is an auxiliary to the class room teacher in th endeavor to solve the problems that the children of this school present. She interprets to the class room teacher, the out of school life of the child and to the home the aims, the problems, and the work of the school, particularly in reference to the child in that home. In her interpretations her object is to get these two forces, the home and the school, which operate in the child's life to work in unison and harmony. It is the harmonious working of these two agents that enables the child to get the most from his educational opportunities.

However, to understand the work of the visiting teacher at the Morris School it is necessary to understand the concept of the visiting teacher as interpreted by the Visiting Teacher Department in the Louisville public school system for it is under the guidance of this department that the personnel work in the Morris School is done.

The present visiting teacher department was inaugurated in the public school system in Louisville, Kentucky in 1926. Prior to this, in Louisville, the public school system employed only attendance officers whose chief function was to enforoe the school attendance laws. For some time before 1926 there had been a growing realization In some parts of the country that schools were faced with other problems besides attendance which affected the lives of children. 
In 1906-1907 a worker known as the visiting teacher appeared in the field. She began her work first in New York $C_{1 t y}$, Boston and Hartford, Connecticut. In these communities, as well as later in others the impetus for this work came from outside agencies. These organizations privately maintained the work until school boards recognized its value and incorporated it as a part of the system. 1

"The chief function of visiting teacher work," says Jane Culbert, "Is to help the school to study and adjust the ohildren who present problems of poor or falling scholarship, of unsatisfactory relations with companions, of behavior or personality difficulties."2

In her work the visiting teacher took from the olass room teacher the major responsibility of solving the problems. Because of this she was able to handle only a relatively small number of cases.

From the work of the attendance of ficer and of the visiting teacher developed a still broader view of personnel work. This viewpoint was based on the philosophy that the behavior of children is due to a multiplicity of reasons, and that an overt act is merely a symptom of some underlying cause, and because the reasons for children's behavior are so intertwined, it is wiser for one worker to handle all the problens dealing with children in a given district. The following quotation from Heck expresses this philosophy. Work, p. 25

1 Nudd, Howard R., The Purpose and Scope of Visiting Teacher 2 Culbert, Jane F., The Visiting Teacher p. 31 
Originally, an attempt was made to distinguish between the work of the attendance supervisors and visiting teachers by saying that the former handled attendance problems, whereas the visiting teacher restricted herself to those children who attended school but who had other problems. Today, of course, we are realizing that these distinctions are largely artificial; the child who attends school but who is a disciplinary case may be as poorly adjusted as the child who plays truant. These maladjustments are merely symptoms; the causes back of these symptoms may be identical. In all such instances the job of the attendance supervisor and that of the visiting teacher are identical, if these problems are to be solved satisfactorily. 3

Thus, accepting this broader viempoint, the present visiting teacher department was inaugurated in the public school system of Louisville, in 1926. The title "visiting teacher" was adopted because at the time it was the name in popular usage.

A concentration of all personnel work in one individual, simplifying as it does all contaots with the home, eliminates the confusion in the minds of those persons in the homes; it simplifies for the school its contacts with personnel workers; it enables the Visiting teacher to handle problems of a more serious nature in the home wit thout coment from the neighbors. This concentration enables the visiting teacher to have a closer, a more intimate and thorough contact with the family and as a result enables her to foresee and forestall many problems. It gives the visiting teacher a more complete picture of the situation affecting the child and consequently

3 Heck, Arch O., Pupil Personnel in the Public Schools,
pamphlet. p. 6 
she can give to the class room teacher a composite picture of the child. Lastly, with her knowledge of the entire social service and health fields, the visiting teacher is in a position to call on these specialists if necessary.

Under this broad view of personnel work the visiting teacher may be likened to a family physician. Because she has such an intimate knowledge of the family, because she handles questions of every nature, because she is called into the home on all occasions, she has the confidence, the respect, the good will, the cooperation of every member of the family. If necessary, she is in the position to call in the specialist, and, because of her intimate contact with the family is able to pare the way for the specialist. 


\section{CHAPTER II}

THE WORK OF THE VISITING TEACHER IN TER

GEORGE W. MORRIS SCHOOL 


\section{CHAPTER II}

\section{THE WORK OF THE VISITING TEACHER IN THE}

\section{GEORGE W. NORRIS SCHOOI}

It is of greatest importance in the performanoe of a visiting teacher's work that she be a recognized part of the school. The more closely a visiting teacher is identified with an individual school the more effective her service oan be. Since the purpose of this thesis is in part to illustrate how some of the problems of pupil personnel are handled by the visiting teacher at the George W. Morris School it is desirable not only to understand how much she is identified with the sohool but also how she organizes and executes her work and the relation she has with agencies outside the school. Therefore, this is the purpose of this chapter. The inadequaoies of the school building, the crowded office space, the lack of privacy for interviewing were desoribed in a former section of this thesis. In the reading of this chapter it should be kept in mind that the visiting teacher at the Morris Sohool is confronted with the problem of working under these undesirable conditions.

During the school year 1938-1939 the visiting teacher worked in the Morris School half of each day. She reported to the school at eight-fifteen three mornings of the week and at nine-thirty the other two days. She helped enroll the new ohildren, cheoked consus work with the clerk, interviewed mothers who came to the school, and talked with teachers and children. She sometimes visited the class- 
rooms to observe special children or sometimes merely to see what was going on. She often used the activities of the class room in working in the homes. Further, through this informal contact with the class the children learned to know her as a part of the school and to sense her interest in the sohool and in them. In interviewing the teachers and children at school the visiting teacher endeavored never to interfere with or interrupt the work of the class room. She adjusted her time to the free time of the teachers and children. This interviewing was done before school, after school, or at recess. Some of the visiting teacher's time in the school was spent in studying past sohool records of the children with whom she was working. Morkers from social agencies often came to the school for interviews. Mothers, social workers and other visiting teachers frequently telephoned her at sohool. The principal and visiting teacher had a conference each moming. The work of the previous day was discussed, the daily attendance record of each class examined and the new problems which the principal or teachers wished referred to the visiting teacher were presented.

The visiting teacher then planned her day's work in the district. She organized her work, planning what she hoped to accomplish that day. However, she kept in mind that she should not be bound by her plan because she knew that often when she would visit a home, problems would arise of which she knew nothing or perhaps she would be seen in the neighborhood and called into a home which she had not planned to visit. 
She also knew the handling of these problems immediately may prevent more serious difficulties, later. Twice a week, on Monday and Wednesday, she reported to the central of fice at the Board of Education. She was free to go to the Director of the Visiting Teacher Department at any time that she felt it necessary. Just as the visiting teacher adapted her plan as the work of the day developed, so she adjusted her time to the parents with whom she worked. As a consequence of this, some of her work was done at night, on Saturdays and even sometimes on Sunday.

The following table shows the number of cases handled by the visiting teacher at the Morris School during the se hool year 1938-1939. This statistical record was kept by the cause of referral and not by the final diagnosis of the case. This table also shows a comparison of the work in the Morris School with the white schools of the Louisville Public School System for that year. 
NUMB ER OF CASES REFERRED TO THE VISITING TEACEER AT THE GEORGE W. NORRIS SCHOOL AS CONPARED WITH THE NUISER OF CASES REFERRED TO THE VISITING TEACHERS IN THE PUBLIS SCHOOL SYSTEM (WHTTE) FOR SCHOOL YEAR 1938-1939

\begin{tabular}{|c|c|c|}
\hline $\begin{array}{l}\text { Cause of } \\
\text { Referral }\end{array}$ & $\begin{array}{l}\text { Number Cases Referred } \\
\text { George } W \text {. Morris } \\
\text { School }\end{array}$ & $\begin{array}{l}\text { Number Cases Referred } \\
\text { Louisvilie Public } \\
\text { School System (white) }\end{array}$ \\
\hline Attendance & 390 & 52,421 \\
\hline Behavior & 16 & 1,391 \\
\hline Health & 25 & 1,731 \\
\hline Scholarship & 25 & 1,584 \\
\hline Tardiness & 21 & 1,389 \\
\hline $\begin{array}{c}\text { Investigation } \\
\text { for Books }\end{array}$ & 5 & 970 \\
\hline $\begin{array}{l}\text { Investigation } \\
\text { for Lunches }\end{array}$ & 96 & 522 \\
\hline $\begin{array}{l}\text { Investigation } \\
\text { for Christmes Baskets }\end{array}$ & 25 & \\
\hline Others & 59 & 763 \\
\hline Number Census Calls & 539 & 19,771 \\
\hline Total & 1,201 & 70,542 \\
\hline
\end{tabular}


This record was kept merely for statistical purposes and really gives little insight into the situation. However, the large number of referrals made because of irregular attendance indicates how often attendance was the symptom of some form of maladjustment. This statistical study also fails to give a complete picture of the work of the visiting teacher because as a result of her intimate knowledge of the district and of the families and children who lived in the district she handled for the school year 1938-1939 many problens which arose without making any home or agency contacts. The handiling of such problens wes not kept in the statistical record. For example, many questions of rellef were handled in this manner. Also, the visiting teacher was consulted on the handling of many class room problems involving the better understanding of individual pupils.

Beside being an integral part of the school, it is not only highly desirable but necessary that the visiting teacher at the Morris School maintain the best possible woriking relations with the various social agencies. Because of the low economic status of the majority of families of the distriot, because the district ranks high in delinquency, because of the large number of broken homes, because so many of the mothers are gainfully employed outside of the home many problems develop in which the visiting teacher needs the help of the social agencies.

The risiting teacher of the Morris School had certain 
definite techniques which she used to gain and maintain the cooperation of these agencies. In September the visiting teacher at the lorris School called at the Family Service Organization, the Municipal Bureau of Social Service, the Children's Agency, the Jewish Welfare Association, the lental Hygiene Clinic, the Home of the Innocents, Nother's Aid, the Neighborhood House, and the Union Gospel Mission. Her purpose was to renew relationships with the workers and to meet any new workers who have been assigned to the Morris School district. She went over the case loads with the workers and in doing this she not only obtained an insight into the changes that had taken place in the district the preceding sumner but she also, particularly with the new workers, was able to give them information concerning their various clients. The visiting teacher at the Morris School also attended any case conferences to which she was invited by the various agencies. For the school year 1938-39 she did not belong to a District Conferencel of the Family Service Organization but when any of the families represented in the Morris School were under discussion she attended the conference. It was the custom of many of the social worers of the various agencies to lunch at a drug store in the Morris School neighborhood. The visiting teacher made a habit of lunching here as often as possible.

1 District Conference of the Family Service Organization, a monthly meeting, composed of lay people, school representatives and social workers, the purpose being to discuss problems of the families known to the agency. 
This enabled her to become better acquainted with the workers. Then also the social workers telephoned or visited the school frequently in order to obtain information concerning the children of their clients. The visiting teacher always tried to give them the desired information. Sometimes the visiting teacher invited certain social workers to visit the school so that they might become better acquainted with the school. Using such methods, as the above mentioned, the visiting teacher was able to gain and keop the cooperation and good will of the social workers in this district. She not only gained an insight into their function and philosophy, their difficulties and their limitations but she also helped then to obtain a better understanding of the function, the philosophy, the problems and limitations of the Morris School. She also built up in the social workers a confidence in her insight and judgment so that the requests she made were usually carried out or the cases which she referred to the various agencies were accepted. However, if she reached an impasse with any of the social workers she referred the problem to the head of the visiting teacher department who in turn consulted the head of that particular agency.

Several 1llustrations will suffice to show the use of which the visiting teacher made of the various social agencies. 
(1) In family $X$ the father had deserted, the mother worked and earned $\$ 2.00$ a week. She had two children attending the Morris School. The children became sick, developed scarlet fever and the mother had to stay at home to care for them. With her small income she was able to save very little and in this emergency this was soon used up. The visiting teacher foresaw the noed, gave the mother a note to the Municipal Bureau of Social Service explaining the situation and the Bureau provided holp during the children's illness.

(2) In family $Y$ the father was dead. There was one child, a girl, ten years old. The mother was not employed but her parents who lived near the city sent money to her regularly each week. The child was absent frequently from school with no apparent good reason. The mother claimed that she was 111 much of the time. The visiting teacher suspected that the mother was using narcotics. The gossip of the rooming house in which the family lived substantiated this. The visiting teacher found that Mrs. Y's parents visited her every Friday morning. The visiting teacher purposely called one Friday morning. The parents discussed their daughter's physical condition in a general way with the visiting teacher and she in turn discussed the child's irregular attendance. When the visiting teach or left, the grandmother followed hor from the room and asked to talk with her privately. An appointment was made for the grandmother to come to the school. Both grandparents came and told of their daughter's habit of taking dope. The visiting teacher explained the function of the Children's Agency and advised the grandparents to apply there for help. The visiting teacher called the agency and made an appointment for the grandparents. However, previously she had discussed the case with the application worker at the agency. The result was that the child was placed in a foster home and the mother was sent to an institution for treatment.

(3) Family $z$ was composed of a mother, father and four children, three of whom attended the Morris School. The father was an alcoholic and did not work. He claimed to have an ulcer of the stomach. The mother supported the family by selling wash rags, etc., from door to door. She was hit by an automobile one day while at work and was seriously injured. She was taken to a private hospital by the owner of the car. The Family Service Organization had been active in the family but had recently closed the case. The accident happened on Friday. On Monday the older child stayed at home to car for the baby, the two younger 
children came to school, told the teacher of the mother's accident. The teacher in turn reported it to the visiting teacher. The visiting teacher irvestigated, found that the landlady had been feeding the children, that the father had been home but little since the mother's accident and according to the oldest daughter had been brutal in his treatment toward the children. The visiting teacher knew the Family Service Organization had been active so she consulted this organization. The F.S.O. called in the aid of the Jurenile Court which took the children out of the home, placed them in the Children's Center and later sent them to relatives where they stayed until the mother's recovery.

(4) James' mother and father were divorced and both remarried. He lived with his maternal grandmother and stepgrandfather. The grandfather was past seventy, was incapacitated for work and spent most of his time visiting relatives. The grandmother was employed on a W.P.A. project. The class room teacher in talking with James found that he stayed at home in the afternoons, and entertained himself by reading stories from cheap magazines. She felt the child should have more wholesome recreation and referred the case to the visiting teacher. The visiting teacher called in the home and discussed the situation with the grandmother. She told the grandmother about the Neighborhood House and also about the Y.M.C.A. and gained the grandmother's consent for James to attend both of these. The visiting teacher then contacted the worker at the Neighborhood House and also of the Y.M.C.A. where she obtained a membership for James. She then arranged for a boy in James' class who attended both of these institutions to take James and introduce him to the workers there. James Became very interested in his new sources of recreation and sometime later the school had a note from the grandmother thanking the school for its interest in the boy and the class room teacher reported that the boy was taking a great deal more interest in his work. 


\section{CHAPTER III}

A DISCUSSION OF THE PROBLEMS WHICH TEE CHILDREN OF THE GEORGE W. MORRIS SCHOOL PRESENT TO THE SCHOOL, ILLUSTRATED WITH CASE STUDIES 


\section{A DISCUSSION OF THE PROBLEMSS WHICH THE CHILDREN OF THE GEORGE W. MORRIS SCHOOL PRESHNT TO THE SCHOOL, ILLUSTRATED WITH CASE STUDIES}

In the introduction three facts concerning personnel problems of a school were pointed out. These facts were (1) that any school, it makes no difference in what locality it may be located, has

personnel problems, (2) that the personnel problems of any given school are in a measure the reflection of the life of the community in which that particular school is located and (3) the problem may be the same in any school, but to some extent, at least, the contributing factors differ as the community differs. In the introduction it was also pointed out that the child's environment includes not only the community in which he lives but also the school to which he comes. Further, it was pointed out that in dealing with personnel problems it is necessary to know as much about the individual child as possible, his home and community life, his physical and mental ability and his attitudes and wishes.

This thesis has shown through a socio-economic study of the Morris School distriot the kind of neighborhood in which the school is located. It has also shown the strengths and inadequacies of the school and the facilities afforded it for personnel work. Therefore, it is the purpose of this chapter to discuss some of the problems which the children of this community present to the school and to illustrate by means of case studies how some of the problems of the 
children who attend this school are treated.

As a mater of record keoping the number of cases referred to the visiting teacher are kept by the cause of referral. Often the cause of referral does not indicate the real nature of the case. For example, absence from school may be merely the symptom for some deated underlying cause. Table XXXII in Chapter II of this section shows that of the 1201 cases referred to the visiting teacher for the school year 1938-1939, 390 of them were referred because of atendance. In a community in which the people live under such crowded conditions, in which the mobility of the district is high, in which the economic status of the majority of families is low, in which many of the families seek the aid of social agencies and in which the rate of delinquency is high, it is to be expected that the school is confronted with the problem of irregular attendance. In order to see the picture as a whole and also for analytical purposes, the absence of each school in the public school system in Louisville is distributed by causes. Then a compilation of all the schools is made, so that a picture of the entire system may be seen and studied. The following graph shows the causes of absence in the Morris school, as compared with the system, for the school year 1938-1939. 
PER CENT OF ABSENCE BY CAUSES OF THE MORRIS SCHOOL AS COMPARED WITH THE LOUISVILIE PUBLIC SCHOOL SYSTEM FOR THE SCHOOL YEAR 1938-1939

Public School System

Morris School

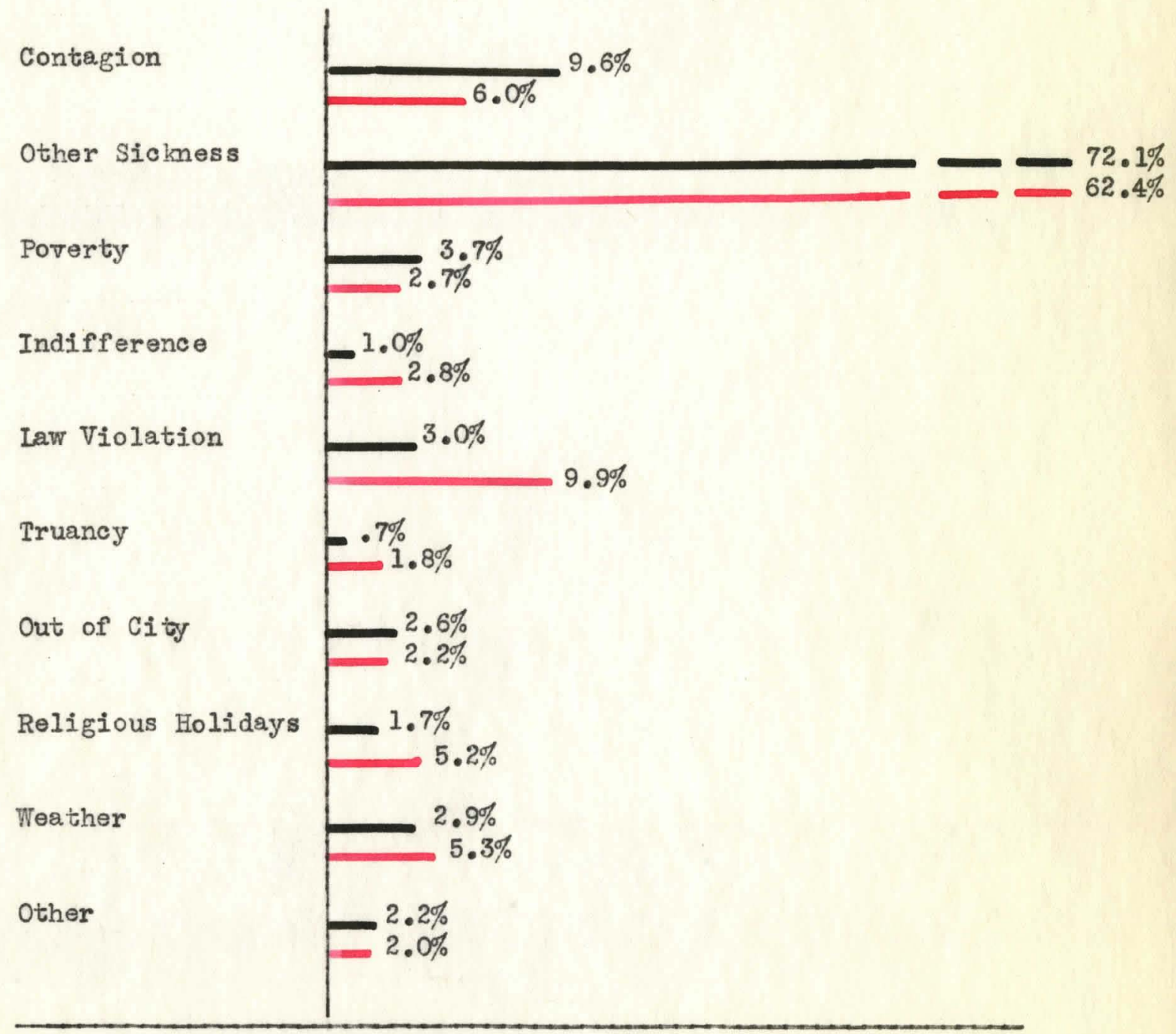

1 Attendance Records, School Year 1938-1939, Files, Attendance Department, Board of Education, Louisville, Kentucky. 
It will be noted from this graph that at the Morris School the causes of absence which rank higher than the system for the year 1938-1939 were law violation, truancy, religious holidays and weather. The Morris School ranked lower than the system in contagion, other sickness, poverty, out of the city and others. None of these causes can be eliminated but they can be kept at a minimum with the visiting teacher and the school working together.

In the Morris School various means are used in an attempt to keep these causes at a minimum. In the case of absence due to contagion, the control lies within the health department. The child may not return to school until released by the school nurse. If, for some reason, the nurse does not release the child at the end of the period of contagion, neither the school nor the visiting teacher has the authority to do so. However, there are some definite things the visiting teacher can do. In the Morris school district where the want of money is such a problem, where ignorance and indifference prevail the parents often do not call a doctor when the children are sick. However, the children are absent from sohool and of ten the visiting teacher is the first to know of contagion in the homes. She reports these cases to the school nurse immediately. She also always notifies the mothers in the immediate neighborhood of any contagion and gains their cooperation in keoping their children close at home. She also informs the class room teachers and they in turn watch the children and exclude any from sohool who show signs of not feeling well. 
In the case of absence due to sickness, if the child is malnourished due to the inadequate income of the parents and has frequent colds and is consequently absent, the risiting teacher has no funds to supplement the income. If a child has frequent headaches and eye strain is found to be the cause and the family cannot supply glasses, the visiting teacher is dependent upon the Parent-Teacher Association, an outside agency or an individual to meet the need. However, there were some things she can do. The visiting teacher at the Morris school helps many of the parents to realize the value of physical examinations, of having physical defects corrected if possible and of teaching the children regular health habits. Also in some of the marginal economic cases the visiting teacher helps the mother plan a well rounded diet for the family. Also, the visiting teacher enlists the aid of the class room teacher in many of these cases. The class roon teacher, through her hoalth work, gains the interest and cooperation of the children in observing regular health habits.

In the absence due to poverty much of $i t$ is prevented through the cooperation of the mothers, teachers, visiting teacher and social agencies. If a teacher notices a child wearing inadequate clothing she reports this to the visiting teacher. Often if a child noeds clothing and the family cannot meet the need the mother comes to the visiting teacher for aid. During the school year 1938-1939 the visiting teacher gave requisitions for clothing for school children on the Municipal Bureau of Social Service for any families in the low 
economic bracket and not active with any other social agency. Also an interested individual gave the visiting teacher money overy month to buy shoes for any needy children. The fact that the visiting teacher always had money with which to buy new shoes for the children who needed them may partially account for the absence due to poverty at the Morris School being less than that for the Louisville Public School System.

In the study of the school enrollment it was shown that there were seventy-two children either foreign born or of forelgn descent in the school. The families of these children observed a number of religious holidays during the school year. In a democratic country where the constitution gives every one the right to worship according to the dictates of his conscience, the school has no right to foroo attendance on religious holidays.

In a district where many of the children are inadequately clothed and poorly nourished, inclement weather is a deterrent of regular school attendanco.

There are two forces at work in the lives of children to keep them in school. One is the push of the home and the other is the pull of the school. In the absence due to indifference, truancy, out of the city and others the control in the main lies in the ability of the visiting teacher to analyse the problem and gain the cooperation of the family and child in the interest which the class room teacher displays toward that particular child. The absence due to law violation 
as has been pointed out is greater at the Norris school than for the city. In a community which has so many disintegrating forces at work as this one, this is not surprising. In the cases of law violation the visiting teacher uses every means at her command to solve the problem before turning the case over to court. If her efforts fail she then, with the consent of the principal, refers the case to the director of the visiting teacher depertment who in turn refers the case to the attendance officer. The visiting teacher then has no further contact with the case and she never appears in court. The accompanying graph shows the per cent of absence of the system as a whole. Generally, the absence of the Mor ris School follows that of the system. While the per cent of absence for the Morris School was greater than the average for the system for the school year 1938-1939 the difference was not as great as might be expected. Obviously, the reason for this was that overy effort was made to foresee, to prevent and to mitigate the causes of absence. 
PER CENT OF ABSENCE BY MONTH OF THE LOUISVILLE PUBLIC SCHOOL SYSTEM (WHITE) AND OF THE GEORGE

W. MORRIS SCHOOL FOR THE SC HOL YEAR 1938-1939

System

Morris School

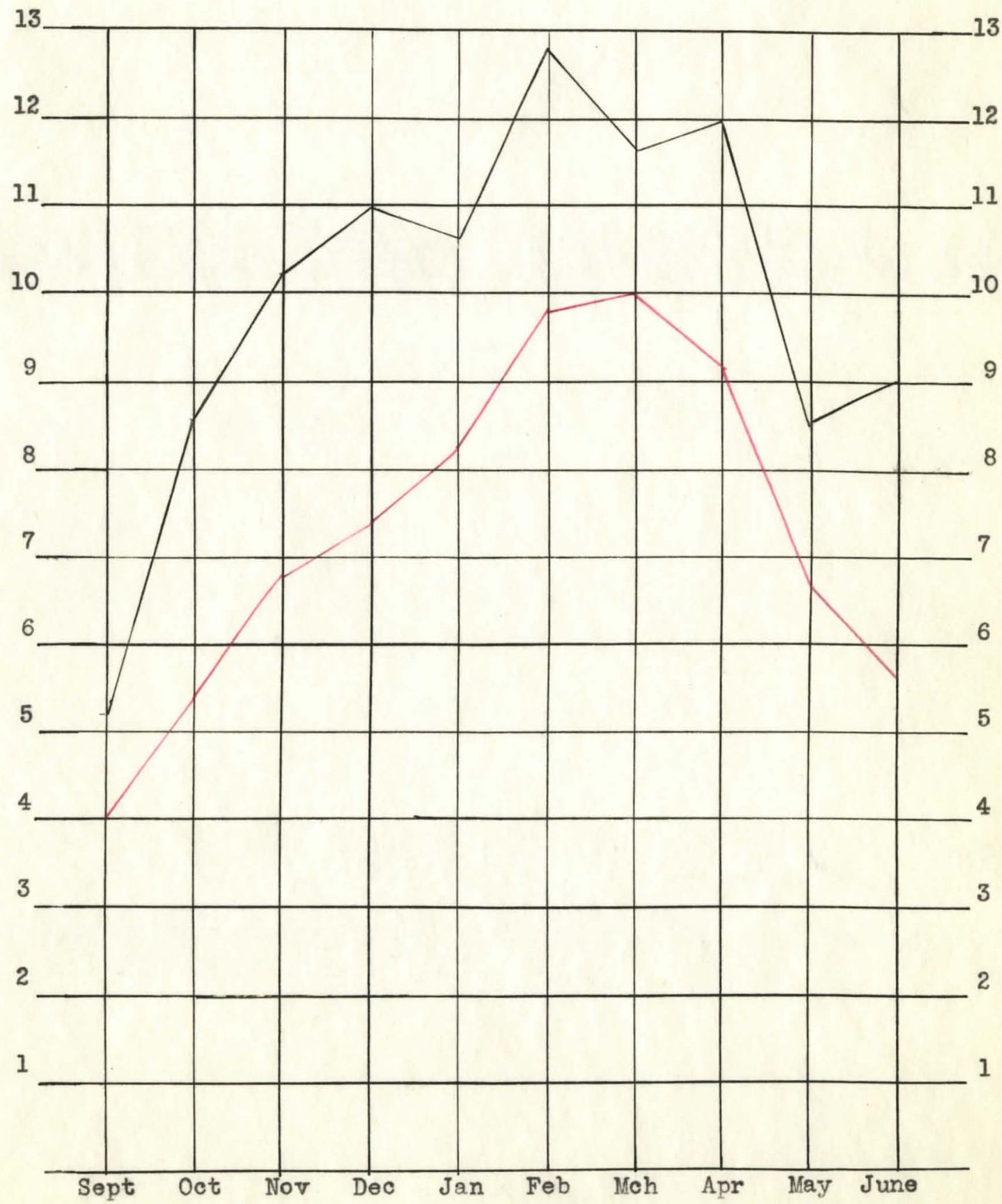


As has been pointed out the reason for referral does not indicate the real nature of the problem. If a child is absent from school this is only a symptom of some underlying problem. Therefore, the fact that 390 of the 1201 cases referred to the visiting teacher were referred because of attendance is no indication that these were attendance cases only. There were often problems of health, poor scholarship, and behavior which were causing the child's absence from school. However, for the school year 1938-1939 the visiting teacher had 71 cases referred her on account of behavior, health, scholarship and tardiness. Again these were only symptoms and there were often many causes for a single problem. The handling of some of these will be illustrated later through case studies.

Also during the school year 1938-1939 the visiting teacher made 539 census calls. This large number of census calls is a direct reflection of the mobility of the community.

The following case studies are illustrations of some of the typical problems which the children of the George W. Morris School present to the school. These studies a lso illustrate the treatment of the problem.

The study of James Smith illustrates (1) how Irregular attendance may be the symptom but how poverty, low mentality, indifference of the home, sickness and behavior all are contributing factors; (2) how a knowledge on the part of the visiting teacher of the facilities of the school, of the personality and ability of the teacher as well as a knowledge and understanding of the child are 
necessary in treatment; (3) how a social agency and the visiting

teacher work together; (4) how effective and necessary in a neighborhood such as this is the pull of the school.

\section{JAMES SMTTH}

James was one of fourteen children, three of whom were dead and eight of whom lived at home. He was fourteen years of age and the next oldest living at home. He was undersized and usually his personal appearance was unlcempt. When he was eight years of age he had had an accident to his eye, and as a result the oye had to be removed. He sometimes wore a glass eye. His physical examination showed him undernourished. For the first ten years of his life James lived in the country. Hore his school attendance was very irregular. In the four years he had lived in Louisville he had attended two different schools. One he attended only a short period. Increasingly, each year he became more and more of a problem. He was not liked by the children. His past school record showed him to be impudent, surly, and defiant in the classroom and he was often truant. The family had lived for three years in an industrial-residential neighborhood. In this neighborhood James had acquired quite a reputation for being "the tough guy". No one in the neighborhood liked him. He stayed at home as little as possible and spent most of his time wandering around the streets.

The parents were borm and reared in the country. Both were ignorant and illiterate, neither having attended school beyond the fifth grade. The mother was fifteen and the father nineteen when they were married. The father was a tenant farmer and eked out a miserable existence for the family. Several months before the family came to Louisvilie, Mr. Smith had a mental breakdown and was sent to the Central State Hospital. He was released in three months. As a result of his disability and his absence from home, he lost his place on the farm. When he returned from the hospital his $f$ mily were living with relatives. He decided to bring his family to Loujsville, in the hope that he and the older daughter could get work.

After moving to Louisville, Mr. Smith obtained odd jobs and the daughter found work as a domestic. She earned six dollars a week. The mother, who showed little initiative, was a shiftless, indifferent housekeeper. She had little or no control over her 
children, and more and more the responsibility of the household fell on the older daughter's shoulders. Mrs. Smith, unused to oity life, seldom left home. She let he chjldren do the marketing for her. Fer attitude toward the children's school life was indifferent. She made little or no effort to keep them in regular attendance.

The family lived in a mun-down four room cottage. It was scantily furnished with several beds, a kitchen stove, table and cupboard and a few chairs. There was no floor covering, and the house was usually dirty and uncared for.

After the family had lived in Louisville about eighteen months, the father began to show marked signs of mental disorder. He was suspicious of his wife, accusing her of going with other men. He became overly anxious regarding the children, and insisted that they remain in the house. He would of ten fly into a rage and frighten them so that they would run to the neighbors.

At this time the family applied to the Family Service Organization. This organization worked with the family for the next two and a half yoars. The Mental Hygiene Clinic studied the family problems, and at the beginning of the second year the father was again sent to the Central State Hospital. He remained there for about a year and was again dismissed. During the time he was out of the home the older daughter assumed the mojor responsibility in the house. Then the father returned home she married. The Family Service Organization referred the case to the Municjpal Relief Bureau of Social Service, and the case was accepted by them.

At this time it was decided that perhaps if the family were moved into an entirely new neighborhood it might effect some change in the family, particulariy James. The family moved into the Morris School nelghborhood. The visiting teacher in the school from which James came gave the visiting teacher at the Morris School a history of the case. She said that probably none of the child ren would enter school voluntarily.

The first step was to give the principal at the Morris School an account of the problem. It was decided for the visiting teacher to call at the home. She made her call in the morning. James was not there, but Mr. and Mrs. Smith and the rest of the children were. The risiting teacher explained that she had heard the family had mored into the neighborhood and that she had called to welcome them into her school. The visiting teacher wove into the general conversation which followed something of the Norris School. She told about some of the activities of the school and 
something of the personality of the teachers the various children would have. When she left, she invited the mother to come to school with the children when she entered them. The visiting teacher's object was two-fold, first, the Morris School encourages mothers, and particularly new ones, to visit the school, and second, the visiting teacher felt that if the mother came and brought the children, James would be more likely to come.

The visiting teacher then consulted with the principal. There was a choice of two teachers with whom James could be placed. One of these teachers was particularly adept in handling problem boys. She had a bright, cheerful personality. She was fair in her judgments, she was interested in adjusting a curriculum as far as possible to meet a child's needs and she could a lways bo challenged with a difficult problem. So it was decided to place James in this room. The teacher was then given a picture of the boy's background and the problems he had presented at the former school.

The call to the house was made on Friday. On Nonday Mrs. Smith came to school, brought the children, and had James with her. In planning for James' reception into the sohool, it had been decided to let him go alone to his class room. It was felt that with James probably the first impression the teacher made on him would be the lasting and effective one. This plan was followed. James opened the door to the class room, swaggered in, and said, "Well, here I am. I'm the toughest kid in town."

The teacher's quick, pleasant, unemotional reply was, "Well, come in. The tougher they are the better I like them."

James was surprised. The wind was taken out of his sails. He didn't know what to do. He said, "I can't do any work; I haven't any books."

"Oh," said his teacher, "I was expecting you. I have your books, tablet, and pencil roady."

Still accepting the situation in her calm, unsurprised manner, she directed him to his desk, gave him his books, and gave him work, which she had prepared in advance, to do. The class room teacher planned work to suit his ability and let him help her by running errands, etc., as much as possible.

James adjusted remarkably well to the classroom situation. At times he was unruly, he had his outbursts, but the teacher understood him, because she had a picture of the boy's background, and so was placed in a position of knowing how to 
handle him. However, she was handicapped by having so little equipment.for manual work which a boy such as James needed.

In time a new glass eye was obtained for James, and through the worker of the Neighborhood House he became interested in the activities there. About a week af jer James entered the school, the visiting teacher made a call to the home and told the mother how well James was getting a long. After this, every time the visiting teacher was in the neighborhood she stopped at the home. Sometimes it was merely a doorstep visit. In this way she encouraged the mother to have the children clean clothes for school, she helped the mother to foresee the need of having the children's shoes mended before they were too badly worn, or of the necessity of notifying the worker from the Municipal Relief Bureau of the need for new shoes. Thru these contacts she also kept alive in the mother's mind the fact that the teacher and the school were vitally interested in James.

In the Morris School, as the study of the new children attending the school shows, many of the children came from rural communities. These children, as well as their families, were unused to the life of the city and caused a distinct problem to the school. The case of Nary Jones is an example of one of the problems these children present. This case shows an instance were the desire, the willingness or the push of the home is present and wanting to act but is hindered by the behavior of the child. This case also shows the necessity of the visiting teacher having an intimate knowledge of the district. Had she not had this she could not have diagnosed the problem nor planned for the treatment. 
MARY JONES

One day, during her work in the district, the visiting teacher observed a girl about nine years of age who was a strancer to her. The visiting teache" stopped and talked with the child, and found that the family had recently moved to Louisville from the country. The visiting teacher explained who she was, and asked the child to take her in to meet her mother.

$M_{r s}$. Jones was a friendly, pleasant, agreeable person. It was the first time her family had ever lived in the city. They had come because her husband had been offered a regular job. She had three girls. In the ountry school they had been in the third, serenth, and eighth grades. The children liked school and attended regularly. They had excellent health. They were eager to enter the school in the city. Mrs. Jones did not know that all of the children would not go to the same school. Since moving to town she had been so busy establishing her household that she had not looked up the location of the school in that district. She was sorry that all of the children would not go to the same school, but she would bring and call for lary for a few days in order that the child might learn the way. She was glad that the visiting teacher had called, and told her something of the children's schools.

The home, which was three rooms on the second floor of an old store building, was comfortably and adequately furnished. The appearance and attitude of the mother, of the children, and of the home gave the visiting teacher reason to believe that this was a normal, well established family.

Mary entered the Morris School on the following Monday. She came every day that week. The teacher reported that liky seemed to be a normal, average child who quickly adjusted to the work of the class. She had formed several friendships among the children.

On the following Monday Mary was absent. She was absent again on Tuesday. The visiting teacher called at the home. Mrs. Jones said that hiry was sick. It was unusual for her to be sick, but perhaps the excitement of moving to the city had upset her. Mary lored school and liked her teacher as much as the one in the country. The visiting teacher suggested that if Mary did not get better, and the mother thought advisable, the mother could take Mary to the Children's Clinic at the City Hospital. The visiting teacher explained the aim and the use of the clinic. 
On the following Monday Mary had not returned to school, so the visiting teacher made another call to the home. Mrs. Jones was at the same time puzzled over and provoked with lary. She had watched lfary, and Mary was fretful and complained of being sick only in the mornings. By afternoon she was perfectly well. On the previous Friday, "wrs. Jones had taken wary to the clinic, and according to the doctor the child was normal and healthy. Saturday and Sunday mornings Mary had not complained at all of being sick. Monday Mrs. Jones had tried to force Mary to attend school, but the child had cried so hard that Mrs. Jones had finally given up.

The family lived five blocks from school. Mary's sisters went no part of the way with her, as their school was in a different direction. The mother had brought the child the first weok, and there had been no difficulty. From every evidence the visiting teacher had, the child's school life was happy. Sitting there talking with the mother, thinking of the whole situation, the visiting teacher came to the conclusion that the bewilderment caused in the child's mind by the city streets was the difficulty. She and the mother discussed this, and the visiting tercher suggested that she ask a neighborhood child to call each day for Mary. As it happened, a child in Mary's class lived several doors down the street. The visiting teacher visited this home, asked the little girl to see Mary that afternoon, and ask her to go to school with her the next day.

This apparently was the correct diagnosis, for from then until the end of the school year Mary's school attendance was regular.

The overcrowding, congestion, bad housing of this district plus the indifference, ignorance and shiftiessness of many of the families cause children infected with scabies, pediculosis, impetigo and even sometimes bed bug bites to be a major problem to the school. The problem is not only to gain the cooperation of the families in caring for the children properly but it is also one of trying to protect the children who live under better surroundings and who have more careful parents from the embarrassment which children sometimes feel if they get these infections. As a rule all cases dealing with impetigo, 
scabies and pediculosis are referred to the school nurse. Howerer, sometimes the visibing teacher finds herself in a situation where the family and child are deeply affected because of the infection and it seems advisable from a psychological viewpoint for her to handlo the case. The following case is an illustration of this. This case also illustrates the value of the visiting teacher being well lnown in a neighborhood.

\section{ROSIR}

Rosie was the adored baby in a family of five children. There was seven years difference in age between Rosie and the next child. She was a healthy normal youngster with curly, black hair which was the pride of the family. The family had lived in this neighborhood for a number of years. The mother had attended the Morris School. She was an extremely emotionel, high strung person.

Rosie was absent from school for a reek. The risiting teacher made no call into the home since she knew this to be a thoroughly reliable family. On the sixth day of Rosie's absence the mother visited the school. The pincipal and visiting teacher were present when the mother entered the office. The mother was greatly disturbed and apparently could do nothing but wring her hands and moan, "Oh, my Rosie". The principal and visiting teacher were unable todiscover the source of the trouble. Finally, the visiting teacher suggested that the mother return home and that she would call in the home later in the morning. The mother agreed to this.

Then the visiting teacher called Rosie was no place in sight. The mother was still moaning, "Oh, my Rosie". No one elsewas at home. After a few attempts to quiet the mother and discover the difficulty the visiting teacher said, "Now, I can't help you unless you tell me what is wrong."

The mother replied, "I can't, I can't, you might tell."

To this the visiting teacher answered, "Haven't I been visiting in this neighborhood for a long time, haven't $I$ been in nearly every 
home on this block, and have you ever heard me repeat anything I have heard in any home?"

This seemed to make an impression on the mother, she became more quiet and said, "My Rosie has lice and she got them at school."

The visiting teacher then talked the situation over with the mother and found that the mother had used the right treatment and had killed the lice but that the child still had nits in her hair. The visiting teacher then requested to see Rosie. Rosie was brought out of the back room where she was in hiding. She felt she was disgraced and could never return to school. She suddenly burst into tears. The visiting teacher examined the child's head and found that apparently there were no live lice but that her hair was full of nits. The mother declared that she had worked and worked and couldn't get them off. The visiting teacher felt that the mother had not tried the right method of getting off the nits so she suggested that she show the mother how it was done. The visiting teacher also wanted the opportunity to calm the mother and to make the child realize that this sort of thing happened to the best of people. She felt by actually working on the child's head she could not only demonstrate what should be done but she would have a better opportunity to lessen the feeling of disgrace. So the visiting teacher donned a high apron, the vinegar was heated, a fine comb was produced and the demonstration proceeded. Thile the visiting teacher worked on Rosie's head she talked about the school and its problems, she told of other little girls who had had the same thing happen, and said that she felt the disgrace lay not in having it happen but in not doing anything about it. The whole situation soon assumed a more normal and even a humorous aspect. The visiting teacher finished her demonstration, scrubbed up and before she left Rosie, the mother and the visiting teacher had a good laugh over the whole thing. In tro days Rosie returned to school and the incident was forgotten.

In his population study Dr. Kutale showed that the Korris School district has a high rate of mobility. A study of the school enrollment for the sohool year 1938-1939 showed the high rate of mobility for the school population. This mobility makes the accounting of the children in the district for the school census quite a problem. The 
purpose of this census is two-fold, first, child accounting, and second, the apportionment of state money to each school district. The census law provides that the school district may receive money for all children between the ages of six and eighteen that reside in the school district. I The age limits for compulsory attendance at school are seven to sixteen years. ${ }^{2}$ It will be noted that the census age and the compulsory school age a re not the same. The census includes the six, sixteen and seventeen year old children, in which age levels same children attend school but many do not.

The visiting teacher in her census work ascertains, first, that all children of school age are in attendance, second, that all children where there is a reason for their not being in school are accounted for in the census and that all non-enrolled children in the six, sixteen and seventeen year old age groups are also accounted for in the census. The state apportionment per child for the school year 1938-39 was 12.12. In the Morris school district where the living conditions are so crowded, where the people move so frequently, where many parents and children are indifferent toward school attendance the visiting teacher must be alert and zealous in her census work. If in her accounting she missed only as few as ten children the school

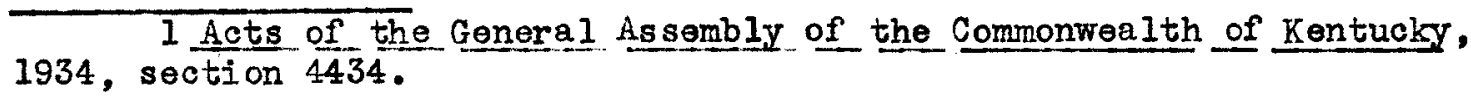
2 Ibid, section 4434-1 
system would lose \$121.20.

The following account gives a picture of the number of calls

it sometimes takes to locate these children.

\section{BEATRICE $\mathrm{X}$}

The family of Beatrice $X$, born April 22, 1922, was lost to the Census Bureau. The family had lived at $831 \mathrm{E}$. Madison, but had moved. The family was traced to $645 \mathrm{E}$. Jacob thru the 1939 directory. However, they had moved again, and all trace of the family was lost.

The family name was then cleared thru the Social Service Exchange. No new address for the family was found, but there were two cross references, one to a $Y$ family at 1612 Fulton, and another to a $Z$ family at $617 \mathrm{Mix}$.

A call was made to 1612 Fulton, but no information was obtained. A call was then made to 617 lix. The family had moved, and a new family, strangers in the neighborhood, had moved in. The woman knew nothing of the family except that some mail had been delivered there for them. The visiting teacher asked if there was any family in the neighborhood from whom she might get the information. After some thought the wom di reoted the visitire teacher to a family two doors down the street.

Inquiry was made here. A friendly, pleasant-faced woman answered the door. She knew the $X$ family, but she did not know where they had moved. However, her husband was at home for lunch, and perhaps he would know. The husband was called. He did not know where the $X^{\prime} s$ had moved, but if the visiting teacher would go to Eighth and Market, to the building on the so utheast corner, the side entrance, and find a woman named Kelly, she probably could obtain the information from her.

Directions were followed, and the woman named Kelly was found. "Oh, yes, her sister, Hazel, had married Coleman $X$, and Beatrice was his sister, and sometimes she and her mother lived with Coleman and his wife. They had moved some place in the st Fnd, but she had not risited them and did not know the address."

By this time the visiting teacher was a little weary of searching for Beatrice, so she must have had a forlorn, dejected look. It 
may be said that this is sometimes the technic she uses. This probably aroused Mrs. Kelly's desire to help, for she volunteered that if the visiting teacher would go to Mrs. Kelly's mother's home on the third floor of $812 \mathrm{~W}$. Market, she might get the address. The visiting teacher knew the dwellers of $812 \mathrm{~W}$. Market since that was a part of one of her school districts. "Oh," she said, "Were you a Bradley? May goes to the Prentice School now." Mrs. Kelly was a Bradley before her marriage, and a sister to May. The visiting teacher then went to Mrs. Bradley, who was an old acquaintance of hers.

Mrs. Bradley was at home. She had been to Hazel's new home. It was up on Franklin Street, but she didn't remember the number and she wasn't sure whether Beatrice still lived there.

"Mamma," said an older daughter, "are you sure it is Franklin? I think it is Washington Streot." Then a discussion followed as to which street it was.

Finally the visiting teacher said to Mrs. Bradley, "Are you very busy? Would it be asking too much to ask you to ride up there with me? My car is right out in front." Mrs. Bradley would be delighted. So the baby was gathered up and Mrs. Bradley, the baby, and the visiting teacher started out, and Beatrice $X$ was found at 719 Franklin Streot.

As a rule the census work is woven in with the other work of the visiting teacher. For example in the case of Beatrice $X$, the call to the Fulton Street address was made on the way home from work. Another day when her work took her into the neighborhood of Mix Street she made this call. On still another day when she was working in one of her other schools a call took her to Eighth and Larket and she completed the work of finding Beatrice $\mathrm{X}$. 
Often it is the shy, retiring, timid, withdrawn children who are overlooked by a teacher. These children present as serious, if not more serious problems as the children whose maladjustment is shown in their aggressive behavior. In the worris school where so many of the children come from homes made insecure through poverty, through separation or divorce, through the mother being out of the home because she has to work, there are many children who show this insecurity by withdrawn behavior. The visiting teacher is always on the outlook for such children. On sereral occasions she noticed a little girl, a new comer to the school, who stood apart from the children. She asked the class room teacher about this child and found that the child was quiet, retiring and timid and seemed worried about something. Her name was Emily. The visiting teacher suggested that she make a study of Emily in order to understand her better and to help her. Through the aid of agency records, through a conference with a worker from the Children's Agency and through several home visits the visiting teacher learned the story of Emily and gave it to the class room teacher. Emily's story is as follows:

Emily, age ten years, was an only child. The parents married when quite young, and the father deserted the mother before the child was born. When Emily was eight months old, the mother left her with the matemal grandmother. A short time after this the father reappeared and took the child to the Paternal grandmother, where she lived for the next; four years, when the paternal grandmother died. The child was five years of age at this time. For the next four years she was shifted about from place to place. She stayed with the maternal grandmother, with three different aunts, and also in three 
different foster homes. When Bily was in the foster homes, many of the relatives interfered frequently and made numerous complaints to the agency handing the case concerning the care the child was receiving in these homes. At the time Fmily was first known to the visiting teacher she was living with the father and maternal aunt.

Emily was a frail looking child. When she was six years of age she had infantile paralysis. This affected her right arm. During the summer before she entered the Morris School she had a tonsillectomy. Several days after the operation she hemorrhaged so severely that she had to have five blood transfusions.

The agency record stated that the various relatives who had cared for Emily complained that Emily was hard to control. Bmily told the worker at the agency that her maternal grandmother was "mean" to her. When asked to explain, the child's answer was, "She took my doll and throw it on the floor and broke it." "The maternal grandmother said that the child was afraid to be left alone and when alone would often scream and cry.

The Morris School was the fourth school Emily had attended. Her scholarship and conduct marks had averaged " 2 ". Her school attendance had always been good. Her school record sheet contained the following statement made by the $1 \mathrm{~B}$ teacher:

"Emily does nice work and is well behaved, but she seems to crave affection."

The mother, twenty-six years of age, was born and reared in the country and married at the age of fifteen. Although her husband deserted her, she returned to him on a number of occasions. Since her marriage Mrs. H. had always lived in Louisville. She had recently remarried. Mrs. H. had never shown any sincere interest in Emily. At times she appeared and was extremely indulgent, and then months would pass without her making any effort to see the child. Emily seemed to long for her mother's affection. The child spoke frequently of what the mother had done for her and what she hoped her mother would do.

Mr. H. was twenty-seven years old. He was born and reared in the country. He was the youngest of a large family, and his sister said he was pampered and spoiled. He had an eighth grade education. He was a truck driver, and usually had regular work. When the visiting teacher first knew him he had Emily living with him. An unmarried sister kept house for him. At this time $2 \mathrm{rr}$. H.'s parental responsibility toward Emily seemed to have been aroused, and for a time he apparently took real interest in the child. He said that she was worried over the fear of his not keeping her. 
He said that she often orled when he left home for work and would ask again and again if he was sure that he would return. He seemed to have a very good understanding of the child's problem. The aunt who lived in the home was a middle aged woman with a kindly, pleasant attitude toward Fily.

However, the next fall, just as Emily was beginning to show signs of a feeling of security, Mr. H. remarried. This wife wes a young, ignorant person who had been married before and who had one child, girl, five years old. The step-mother's attitude toward Fily may be expressed by one remark, "Why should I worry about her; she's not mine."

One day Emily made the following remark to the visiting teacher concerning her step-mother: "I call her Alma; I won't call her mother. You know, I can never do anything right. I get blamed for everything." Emily resented the fact that her step-sister was allowed to do anything she pleased, was scarcely ever punished, and carried tales of $\mathrm{mily}^{\prime} \mathrm{s}$ misdemeanors to her mother. Probably due to the step-mother's attitude toward Emily, Mr. H. seemed to lose all the parental responsibility which he had evidenced toward the child.

The maternal aunt who had kept house for Mr. H. and Enily remarried a short time after $\mathrm{Mr}$. H. did. She was divorced from her first husband, she was childless, and said that she had always been interested in the child. She was in her late forties and was a stable, settled, kindly, understanding person. Her present husband, an illiterate, rough, gruff, uncouth person, had never been married before. He was about fifty years of age. He was a laborer and had always had regular work. He seemed to have a deep sympathy for Emily. One day he said to the visiting teacher, "I feel sorry for the kid, and I want to take her if the father is willing."

Mr. H. finally consented for Emily to go and live with the aunt and uncle. The aunt and uncle lived in a rooming house which was a well run, well kept place, and which had always had a good reputation. There was a good-sized back yard where the neighborhood children played, and Emily spent her afternoons playing with these children.

Enily attended the Morris School for a little over three school semesters. After the class room teacher had an understanding of the child's background she began taking particular note of her. She praised her work whenever possible, she gave her special duties, and allowed her to stay after school to help about the room. In many ways the class room teacher endeavored to make the child feel her interest, to give her a sense of belonging. 
Ontil the father's remarriage he seemed to have his interest awakened, and for a while made real effort to holp the child gain a sense of security. Occasionally, he would bring her candy or take her to the picture show with him. When ho remarried he lost all interest again. Each time Emily was promoted the visiting teacher gave the new teacher a history of Emily's background, and each teacher in turn did what she could for Emily.

Enily was in the Morris School for five months after the aunt and uncle took her. One day, after she had first gone to live with them, she said to the visiting teacher, "My Aunt Della and my Uncle Jim haven't had a fight yet." One day some time later the classroom teacher sent Emily to the visiting teacher to show her some work Emily had done. It was a good piece of work, and the visiting teacher said as much. Emily's reply was, "Do you know when my improvement started? It was when I went to live with my Aunt Della and my Uncle Jim."

A short time after this the aunt and uncle decided to go to housekeeping and the family moved out of the Morris School neighborhood.

This study illustrates three things:

First, the timid, shy, retiring child may be overlooked by the classroom teacher, the reason being that this type of child causes no real disturbance in the classroom, and it is only the teacher who has a keen, sympathetic, and understanding insight into child nature who recognizes that the child is a problem and needs help.

Second, this study shows how, with an understanding of a child's background, a teacher's interest may be aroused by the visiting teacher and her aid enlisted in helping the child become better adjusted.

Third, it illustrates the contribution the school has to make to a child's life. In the case of Emily, a child who had known 
little security, the classroom teacher, was able to give to her a foeling that someone was interested, that someone cared.

Although the foreign population in the Norris School District is on the decline, the children from this group not on y present scholastic problems due to language difficulties to the school but also problems of maladjustment which often grow out of the younger generation learning through their school experiences more of the American way of life than their parents know. The case of Jack $\mathrm{N}$. Is an example of such a case. The case also illustrates how the visiting teacher often has to work with the parents, particularly the mother, through an interpreter.

\section{JACK N.}

Jack, twelve years old, was one of five children, and next oldest in the family. His parents were both Syrians. They had recently moved to Louisville from Cleveland. Jack entered the sixth grade at the Morris School. When he entered school, his father came with him and explained that Jack had heart trouble and requested that the school excuse Jack from all physical activity possible. Jack was under the care of one of the leading heart physicians in the city.

The visiting teacher called at the home and found that the mother spoke English but litcle, and so, with the help of the children and many gestures, the visiting teacher conveyed to the mother the idea that the school would do everything possible for Jack. It could easily be seen with what great conoern the mother regarded Jack's physioal condition. The visiting teacher also talked with the heart specialist. He told the visiting teacher that he hesitated to give his consent for Jack to attend school, but that the boy was so eager to attend and worried so over not attending that he had finally consented.

The school made very arrangement possible to save Jack any physical exertion. He was encouraged on his arrival at school 
to sit down and rest on the first floor before he went up to his classroom; he entered no games; his lunch was sent up to him each day. He was encouraged to stay at home if he felt i11. The boy realized the need for care, and on his return home from school he would rest.

One day, after Jack had been in the school a short time, the mother sent word she would like to see the visiting teacher. The visiting teacher called at the home. Both $\mathrm{Mr}$. and Mrs. N. were there. They were upset and deeply concerned because Jack ate little or nothing. When asked why, he only said that he didn't know, he just didn't want to eat. Jack must eat. Could the visiting teacher do anything? The visiting teacher made no promises, but assured them that if possible she would try to help them. There seemed to be no reason why Jack shouldn't eat, the home was clean, the food well prepared.

The next day the visiting teacher sat down by Jack while he was resting before going to his classroom. She told Jack of her visit to the home and of his parent's concern. She then asked the boy if he had any real reason for not eating. The reason then was given by Jack. He said, "In Cleveland I was In the fresh air camp because of my heart. There I learned to like your kind of eating. Now I don't like the Syrian food." He didn't want his mother to know; it would make her feel bad. The visiting teacher led Jack to see that his mother would understand, that she would want to know. The visiting teacher gained Jack's consent to talk with his mother about it.

Another visit was made to the home, and with the help of the older daughter the situation was explained to Mrs. N. It was not such a difficult matter, with the help of the older daughter and a neighbor, to teach Mrs. N. to cook some foods in the American way.

The appreciation of the interest the school took in Jack was shown at the birth of the next baby. The baby was a boy, and he was named "Morris".

Tardiness is another problem which confronts the school. Mothers going to work early, or working until late at night and then over-sleeping; no clocks in the home because of lack of money; heary traffic which retards the children's trip to school; interesting shop windows which cause children to loiter, are all factors which 
contribute toward making the children tardy. At the Iforris School no child is blamed for being tardy until the cause is discovered. The case of Billy and Mary shows how the school handled successfully one case. The case also illustrates the cooperation between the school and an agency.

\author{
BILLY AND MARY
}

Billy and Mary $\mathrm{H}$. both attended the Morris School. Billy was in the $1 \mathrm{~A}$ grade and Mary the 2B grade. The attendance and punctuality of both had been good. In March, 1939, the teachers of the two children began to report that both children were tardy frequently. The children could give no reason for the tardiness.

The visiting teacher knew the family background. Neigher parent worked. The Family Service Organization was active. The parents were having some marital difficulty which this organization was attempting to help them solve. Both parents had a strong attachment for both children. The family lived in a rooming house not quite two squares from the school.

The visiting teacher called at the home and talked with the mother concerning the children's tardiness. The mother sald it was her fault and that she would be more careful in the future. The mother did not give the reason, and the visiting teacher did not press her for a reason. For a day or two the children came to school on time, and then they dropped back into their habit of being tardy.

Again the visiting teacher made a visit to the home. She told the mother that the children were still tardy and that there must be some reason within the home causing the diffioulty. Could the mother tell the visiting teacher what it was? Porhaps the visiting teacher could help in straightening out the problem. Wrs. H. then told about her difficulty. Their alarm clock had worn out; they couldn't make it run. They were the only roomers on the third floor. The landlady lived on the first floor. They couldn't asik her to come up and call them. The visiting teacher asked Wrs. H. if she had thought of asking the Family Service worker for a new clock. Mrs. H. hesitated to do this. The Family Service worker had done so much for her. The visiting teacher explained to lirs. H. that the Family Service worker would 
want to know, that she was interested in the children's diffjculties, and that she would help if she could.

The next day the visiting teacher called the Family service worker, told her of the situation, and told her that she had advised Mrs. H. to come and see her. The alarm clock was purchased and the tardiness ceased.

In Part II, Chapter $V$, the retardation in the Norris School was shown by means of age-grade studies, grade-progress studies and achievement tests. Late entrance in school, irregular attendance, low mentality, lack of cooperation on the part of parents and lack of interest on the part of the children are some of the factors contributing toward this retardation. Nany of the pupils who present scholastic problems are studied by the visiting teacher and the cause of the retardation is sought. The visiting teacher and the school working together attempt to eliminate the cause or to make adjustments so that the child in question can get the greatest possible benefit from his educational opportunities. Regular attendance is worked for, cooperation of parents is sought, and attempts are made to arouse children's interest. Many individual tests are given by the psychologists at the Bureau of Research and if a child is found to be low mentally he is often transferred to an ungraded class. Possibly the thing of greatest concern to the teaching staff is the mental inertia of mentally and physically normal children. It is believed that much of this was due to the lack of cultural bac ground in the home, to the lack of interest of the parents, and to mothers too tired from being bread winners to take an interest in their children's schooling. 
The following study illustrates this type problem. This case is an example of the way a child is led to be interested in his school work and how, through the feeling that the sohool is interested in him and wants him to succeed he gradually puts more effort into his work. It also 1llustrates how a mother's attitude may be changed and her cooperation gained.

ROBERT

Robert was referred to the visiting teacher because he was failing in his school work. The classroom teacher felt that Robert had ability, but he made little effort to do his work, wasted his time, and never completed his task. The teacher also stated that the child was evasive and not always truthful.

Pobert had entered the Vorris School in the 2B grade. Prior to this he had attended another school in the city. He was in the 3B grade when he was referred to the visiting teacher. His school attendance had always been excellent. On the PitnerCunningham Primary Test given when he was in the first grade, Robert had a chronological age of seven years and a mental age age of seven years two months. Robert, aged nine, was an only child. According to his mother, he had always had good health. Wrs. H. worked and consequently Robert was alone much of the time. The maternal grandmother lived on the second floor of the same house and watched after Robert to some extent. She said that when Robert would bring home a poor report of his work he would cry and cry. Both the mother and the grandnother said that the child was truthful with them. The visiting teacher. had the opportunity to observe the child in his home on several occasions. He seemed to be a solemn, serious chap, who seldom smiled. Robert had no particular out of school interests. There was nothing in the home of special interest to him. He said he liked books, but the only book the child possessed was a religious book someone had given him. His grandmother said that he spent many an afternoon sitting on the back step doing nothing.

Mrs. M. was in her late twenties. She was born and reared in Louisville. She attended the Morris School thru the seventh grade, and then quit to go to work. She married when quite young, and she and her husband have been separated for several years. Mrs. M. had a very attractive personal appearance. She 
worked in a factory, left home at six-thirty, and did not return until four or after. She earned $\$ 12.50$ a week. On her return home she had to do the house work. Because she was so tired and worn she had little time to devote to Robert. Mrs. M. had a quick temper, and no doubt was often cross and fretful with her son. She felt that when she sent Robert to school regularly and punctually, clean and neat, she was doing as much as should be expected of her. Mrs. M. had lit le recreation. Sometimes she went out on Saturday night. She knew nothing concerning her husband's whereabouts. She felt Robert seldom thought of him.

Robert and his mother lived in two rooms, first floor rear, of an old store building. The rooms were comfortably furnished and well ept, but dark and cheerless.

In working with this child one of the first steps taken was to request that Robert be given an individual test by the psychologist at the Bureau of Research. He was given an individual StanfordBinet mental examination. Following is a part of the psychologist's study:

"Robert impressed the examiner as a very quiet child with a pleasing personality, but it was sometimes very hard to hold his attention. Otherwise, he made a good adjustment to the testing situation. There is considerable scatter, but the results are consistent nevertheless. He seems to have a small range of general information and a short attention span. His memory span for sentences and his ability to reason in a common sense way are average for a nine year old. His highest level of success was the twelve year level, where he passed one test, that of giving similarities, indicating rery good ability to make logical associations. The test indicated that he had average learning ability."

It was felt that Robert had had no opportunity at hore to form any good work habits,---on the contrary, he had formed the habit of idling. The school would have the double task of breaking down one set of habits and helping form another. It was felt also that too much should not be expected of Robert immediately. The classroom teacher planned to give him short assignments, and at his first success she would notify the visiting teacher, and the visiting teacher would visit the home and tell the mother of the success. The classroom teacher had a fow new story books which she had recently acquired. She showed these to Robert and let him have the privilege of being the first to take them home.

A short while after this, Robert met with some success in his classroom. The visiting teacher called at the home that afternoon to show the mother the work. The mother was pleased. During this 
call the visiting teacher had the opportunity of discussing with the mother the child's lack of anything to interest him during his out of school hours. The mo her lnew about the Neighborhood House. In fact, she had gone there as a child herself. If Robert wanted to go there she did not mind. So the visiting teacher arranged with the worker of the Neighborhood Eouse for Robert to go there.

By the classroom teacher's working with Robert, by the holp of the worker at the Neighborhood House, by the visiting teacher's calling at the home occasionally to tell of Robert's growing interest in his work, Robert not only improved his work, but the mother's attitude toward the school was changed. Iittle by little we began to realize that educating a child was a cooperative job. She began to show an active interest in Robert's school work, in the books he brought home, and occasionally, when she was not too tired, she would help him with his work.

If a child had a physical handicap the staff at the Morris Sehool makes every effort to adjust the child's school ife so that the child could remain in school. Often this is a piece of cooperative work of a health agency, the classroom teacher and the visiting teacher. The following study shows the correlation of the work of the visiting teacher with a health agency in having recommendations carried out. It shows how the school made adjustments for a physically handicapped child. It shows the help the visiting teacher was in explaining the resources of public agencies to a fmily whose economic status had changed. And it also shows the part the classroom teacher played through her educational work in helping a child realize the need for physical care. 
ELIZABETH

Elizabeth was the youngest in a family of six children, four of whom lived at home. The family had lived in the Morris School district for a number of years. The four younger children all attended the Morris School.

The parents were both substantial, industrious individuals who were interested in the welfare of their family. The father was an engineer in one of the larger buildings in the city. Although he did not make a large salary, due to his wife's good management the family never wanted. The mother was interested in her church, in holping her neighbors, in caring for her family. Wr. T. kept his job thru the first years of the depression, but when Elizabeth was in the third grade he lost his job. For a while the family received direct relief from the Municipal Bureau of Social Service. During this period the visiting teacher was able to render the family several small services.

Then Elizabeth was in the last part of the fourth grade, the father obtained another regular job, but this time his salary was not so large as previously. In February of the next winter, Elizabeth developed pneumonia and was seriously ill. The family had a private physician. Again, the visiting teacher had the opportunity to perform small services for the child. She took her fruit and gave her a bathrobe to wear during her convalescence. The child did not recuperate as fast as was hoped, and finally the doctor advised that she remain out of school the rest of the semester. The visiting teacher kept in contact with the family. The mother was concerned about the child's health, and she was also worried about the family finances. She was no longer having the services of the doctor. The visiting teacher discussed with the mother the value of taking the child to the pediatric clinic at the City Hospital. The mother finally decided to do this. On examination there it was found that the child had heart trouble. She remained out of school the rest of the semester.

The next year the doctor felt that Elizabeth could re-enter school if certain arrangements could be made to protect her at school. The social worker at the hospital wrote the school giving the school the doctor's suggestions. Elizabeth should not go up the steps but once a day. She should be excused from fire drill. She should play no games requiring physical activity. Her mother would send her lunch to school for her. Elizabeth was to take a rest every afternoon. 
Elizabeth entered school. The classroom teacher was given a history of the case, and all arrangements were made to protect the child. A few days later the visiting teacher called at the home to let Mrs. T. Know what the school was doing. Mrs. T. was having some difficulty with Elizabeth about her afternoon rest. The child did not want to take it, and if she did take it her mother had to force her. The visiting teacher suggested that possibly the classroom teacher could have some influence in helping Elizaboth see the need of the rest. The visiting teacher told the classroom teacher about the difficulty. Thru her health work and thru a private conversation with Elizabeth the classroom teacher helped the child realize the absolute necessity of the afternoon rest. When Elizabeth changed classes in February the visiting teacher gave the new teacher a history of the case. Elizabeth attended school regularly for both semesters. The first semester she missed only two days of school and the second semester six days.

In the Morris School district where children come to school not only from normal homes, but homes affected by poverty, immorality, intemperance, separation or divorce, ignorance, indifference, or shiftlessness, the visiting teacher in her work sometimes in the course of one day may handle every kind of maladjustment that such conditions create.

Her first visit may be to initiate the study of a boy who is presenting a behavior difficulty at school. The family was comparatively new in the district. When the risiting teacher entered the home, she found Catherine, the seven year old, crying with a bad toothache. Catherine's teeth had needed attention for some time, but the family budget did not permit of paying for a dentist. The visiting teacher suggested that she put Catherine's name on the list for free dental work. She then discussed with the mother the boy's difficulty. From here she goes to a rooming house to see a mother who had 
requested a visit. The landlady sees her enter and asks her to come into her room. She tells the visiting teacher about a little boy who lives in the house. Something should be done for the child. Mell, everybody knew what the mother did. She supposed she shouldn't keep them there, but rooming house business was bad enough, and if you got a roomer who paid regular every Saturday night, that was something. But the mother shouldn't neglect the child as she did. Last night she didn't get in until four o'clock. Would the visiting teacher report the case to the right agency?

Then the visiting teacher calls on the first mother who had sent for her. As the visiting teacher knew, this mother should undergo an operation, but the mother would not consent. However, the mother had about made up her mind. She worried, though, about the children. She hated to take them out of school and send them to her mother in the country. They were getting along so well at school. She had heard about the Home of the Innocents. Would the children be well cared for? At least, it waldn't hurt to talk to the worker there. As the visiting teacher was leaving the rooming house another mother stopped her. Would the visiting teacher come in a moment and see all the vegetables the mother had bought at the market for fifty cents. The mother had found that it was ever so much cheaper to market there.

The next call was in a tenement. Here the visiting teacher called on a mother to discuss with her the truancy of her son, Johnny. It was unlike Johnny to be truant, and if it were only a 
a time or two it may not be so serious, but it looked as though Johnny were forming the habit of truancy. And so the two discussed Johnny and his behavior. While in this tenement the visiting teacher went to the second floor to see Mrs. James. She only stopped a minute. Mary's teacher had asked her to tell lirs. James how much better Mary had been doing since she was helping her with her tables. The next call was on a new family who had just moved into the neighborhood. The children had entered sohool that day. The mother had wanted to come to school with the children, but with the care of the baby and the two little ones it was almost impossible. She had a little girl of six, but she was not going to start her to school until next year. She had a boy of sixteen. No, he was not in school. He was hunting for work. Two new children for the census, thought the visiting teacher.

As the visiting teacher left this home she heard her namo called. Mrs. K. was standing in the door of her restaurant. Would the visiting teacher come in and have a coca-cola? So, while the visiting teacher was drinking the coca-cola, ws. K. told of her difficulty. Her Mike brought home a bad mark in conduct and effort on his report. Mike had always received good marts. He had been in the Morris School always. That about that new teacher he had? Well, she knew children sometimes got off the track, and teachers did have a problem, but she wished the visiting teacher would be sure to investigate.

The next call took the visiting teacher into a rooming house. 
Jimmy Mix had been absent from school, and the children had told his teacher he had moved. The visiting teacher stopped in to ask the landlady where the family had moved. The landlady did not know. The Mix's oved her two weeks' rent, and they moved in the night, but Mrs. Green, who lived on the second floor of the rooming house next door, used to visit Mrs. Mix, and perhaps the visiting teacher could find out from her. Irs. Green did know, and gave the new address to the visiting teacher.

From here the visiting teacher called on Lucy's mother. Lucy had bad tonsjis, and they were affecting her hearing. Lucy's father wouldn't consent to the operation. Perhaps if the visiting teacher would talk with him it might have some effect. He did not get home until after six. Could the Visiting teacher come then?

By this time school had been dismissed. There came Nicky down the street. Nicly had a good mind, but he disliked working - He wouldn't study his spelling. If he would study hard and get good marks his father would give him a baseball bat. The visiting teacher stopped to ask Micky about his spelling. His face boamed. He had received a hundred on his spelling test. He dug into his pocket, pulled out a grimy but highly prized paper. He was taking it home to show to his father.

After leaving Nicky the visiting teacher stopped to watch a group of girls jumping rope. She turned the rope a few times. Good, Romana was playing with the children. Every one know about Romana. 
When she was five she darted in front of an oncoming street car. The mother, in saving the child, had been killed. Pomana became a quiet, withdrawn little girl. Her father had died recently and she now lived with a married sister. Romana would not play. She spent most of her afternoons sitting on the doorstep. It was good to see her playing with the children. Tomorrow the visiting teacher would tell Romana's teacher. The teacher would be glad, too.

All of the time the visiting teacher was at work, back in her mind some place she was going over and over the difficulty Robert was presenting at school. No one seemed to be able to diagnose the difficulty. No one had been able to reach the boy. The visiting teacher came to a decision late that afternoon. She would go to the office and talk the situation over with the director. While she was there she could call the Children's Agency and get an appointment with the worker there to discuss the problem the landlady had told her about earlier in the day. She could also call the worker at the Municipal Relief Bureau. Mrs. Brown was at school that morning to tell the visiting teacher that the children's shoes were very bad, and they would have to have new ones shortly. Mrs. Brown had talked to the worker at the Bureau, but the worker wanted to talk to the visiting teacher before she gave her an order for shoes. Just then a lad, seven or eight years old, darted from around the side of a house and called to the visiting teacher. "My mother says won't you please come to our house? The baby's got something." Well, the baby did have something. He was pink all over. The 
visiting teacher did not know what it was. She could not say; she was not a doctor. A doctor should see the child. Knowing that there was no available telephone in the neighborhood except the pay station at the corner drug store, and that a nickel would be a drain on the limited income of the family, the visiting teacher volunteered to call the city doctor. Suppose the baby did have something contagious and the doctor wanted him to go to the hospital. Would the mother consent? The beby would get good care, and the mother should think about the other children. She did not have to make up her mind now. After all, it may not be anything. But she must be sure not to let any of the neighboring children in the house until after the doctor got there. If it were anything contagious the children would, of carse, have to stay out of school. 
SUMMARY AND RECOMIENDATIONS 


\section{SUMAARY AND RECOMENDATIONS}

The George W. Morris School is located in a neighborhood that is an interstitial area which is in the throes of change from residence to business and industry. It has become a slum or semi-sium district. Population studies show that the population in this neighborhood is so dense that the people cannot live comfortably in the type of houses arailable to them, that the proportion of adults to children is abnormal and that the mobility of the neighborhood is very high. A study of delinquency shows that the neighborhood ranks high in jurenile delinquency as well as major and minor crimes as compared with the rest of the city. This area abounds in cheap restaurants, where alleged gambling and drinking take place, in saloons and alleged gambling houses and pool rooms. Prostitution is also prevalent. The lack of playground spece forces the children to play on the streets.

In this district 52.8 per cent of the families who were represented in the school during the school year 1938-1939 had an income that was under the minimum standard budget requirements; 39 per oent of the families were broken through the death of one or both parents, through separation or divorce or through one parent being in a government institution; 20.3 per cent of the families had the mother employed outside of the home; 81.4 per cent of the families had been known at some time to one or more social agencies; and 39 per cent of the families lived in rooming houses, 23 per cent lived in tenements while the others lived in apartments or single family dwellings. 
The George . Korris School, an elementary, public school of six grades is housed in a building eighty-six years old. It is a three story building with comparatively small rooms, no cloak rooms and little modern classroom equipment. The toilet facilities for the children are in the basement, the playground is small and there is no gymnasium. The school lunch room is run by the Council of Jewish Women, an organization apart from the school system. The building affords litile opportunity for the privacy that is required for successful interviewing and conferences. The school is situated on a busy down town comer where the street noises are sometimes very disturbing.

During the school year 1938-1939 the school staff consisted of a principal, a kindergarten teacher, twelve classroom teachers, a visiting teacher and a school nurse. The visiting teacher was assigned to this school for half a day, five days a weok. The school nurse worked under the direction of the City Health Department and had no regular schedule for visiting the school.

During the school year 1938-1939 there were 608 children enrolled in the school. Twenty-eight of the children came from the Home of the Innocents and their respective families did not live in the district. The 580 children who lived in the distrjct represented 394 homes. Of these 580 children or 5.8 per cent came from homes of foreign born parents and 34.4 per cent had never attended the school before. This last, in a measure, shows the mobility of the school population. 
The age-grade study and the grade-progress study for the school year 1938-1939 coupled with achievement tests of previous years all indicate that the pupils of the Morris school were, on the whole, deficient in accomplishment in comperison with the pupils of the white elementary schools of the Louisville Public School System. The personnel work in the George W. Horris School is done under the guidance of the Visiting Teacher Department of the Louisville Public School System. The underlying philosophy of this department is that the behavior of children is due to a multiplicity of reasons and that an overt or withdrawn act is merely a symptom of some und lying cause and because the reasons for children's behavior are so intertwined, it is wiser for one worker to handle all the problems dealing with children in a given district. Therefore, at the George W. Morris School, the visiting teacher handles the personnel problems. However, the personnel work is a piece of cooperative work between the classroom teachers and the visiting teacher. If the classroom teachers did not recognize the problems, refer them to the visiting teacher and then act upon her findings and suggestions much of the effectiveness of the visiting teacher would be lost.

Although the children of this school present the same problems that children of any school may present, the contributing causes are in the main the reflection of the life of the community. Some of these causes are the effects of overcrowding, the problems resulting from the low economic status of the families and the high rate of mobility 
of this district. The case studies illustrate some of these problems and also demonstrate how they are treated. Thus, from this study the following observation may be made. In a school where the children come from a neighborhood where there are so many factors that may contribute toward all forms of maladjustment, in a school that is physically inadequate, in a school where the children are low in acomplishment, a responsibility, a burden is placed on the teaching staff . . the responsibility of endeavoring to mitigate, to overcome, as far as possible, the influences which create these problems. The visiting teacher is an auxiliary to the class room teacher in this endeavor. She interprets to the class room teacher the out of school life of the child, and to the home the aims, the problems and the work of the school, particularly to the child in that home. She is a link between the school and the agencies for child welfare, interpreting to the school the purpose and work of the agencies and to the agencies the goals and problems of the school. In her interpretations her object is to get these forces which operate in the child's life to work in unison and harmony. It is the harmonious working of these agents that enables the child to get the most from his educational opportunities and to be able to develop a more wholesome and a more balanced personality. Also, from this study the following recommendations may be drawn.

1. While it is the function of other agencies of the government 
to deal with bad housing, unemployment, low incomes and other deteriorating forces, the school should know the extent of these problems in its community and should be prepared to help mitigate some of the effects of these forces upon the children who attend the school.

2. To accomplish the above, the school should not be dependent upon Parent-Teacher Associations, interested friends and outside agencies for help with school clothing, glasses, or lunches for indigent children. An adequate fund earmarked for these needs should be provided for the school.

3. The Horris School building is eighty-six years old, is inadequate and poorly equipped. At first glance it would seem that this neighborhood should have a new adequately equipped school building. However, in 1938 the proportion of adults to children in this school district was three hundred to one hundred which is much higher than for the United States. This may indicate that each year fewer and fewer children will live in this area. Therefore, in the consideration of a long time building program it may be too expensive for the city to erect a new school building in this community.

4. The curriculum at the Morris School is the one planned for the entire system. The educational needs of these children should be studied and a curriculum to meet their needs formulated.

5. The general report of the 1930 White House Conference on Children recommends one visiting teacher for every 500 pupils. 1

\footnotetext{
1 Thite House Conference on Child Health and Protection, 1930. p. 179 .
} 
Beside the 608 children enrolled at the Morris School during the school year 1938-1939 the visiting teacher had two other elementary schools under her charge. One with an enrollment of about 700 children and another with an enrollment of about 350 children. Therefore, according to this, the visiting teacher at the Norris School was carrying too much work. Less work rould lead to more intensive work on more cases which is needed in this district.

6. If the visiting teacher had a lighter case load she could broaden her work to include the following:

a. visit all new families whose children enter the school and thus form immediately a friendly contact with the family, probably foresee and possibly prevent a problem arising and also be able to give to the classroom teacher a picture of the child's bacicground.

b. make a study of all children entering the $1 B$ grade and thus give the teacher a background of the children.

c. go over the class enrollment with every teacher each semester and thus give her an insight into the lives of many of her pupils.

d. belong to and attend regularly the District Conference of the Family Service Organization.

e. have time to have more and better conferences vith social workers at the school and thus help then get a better 
insight into the problems of the school.

f. regularly go over the health cards of all the children after the medical examination, thus learn the health corrections needed and be enabled as she did her work to help the nurse educate the pents to these health noeds.

g. make an intensive study of the problems of more of the children who are referred to her. 
BIBLIOGRAPHY 


\section{BIBLIOGPAPHY}

\section{A. BOOKS}

Bermejo, F. V., The School Attendance Service in American Cities. Menasha, Misconsin, George Banta Publishing Company, $1 \overline{923 .}$

Burgess, E. W., The Natural Area as a Unit for Social Norl in the Large City. Proceedings of the National Conference of Social Work, 1926.

Campbel1, William Giles, A Form Book for Thesis Wiriting. New York: Houghton Mifflin Compāny, 1939.

Cassaday, Ben, The History of Iouisville from Its Earliest Settlement Till the Year $1 \overline{852}$. Louisvilie, Kentucky: Huli Brothers, 1852.

Chave, Ernest J., Personality Development in Children. Chicago: University of Chicago Press, 1937.

Colcord, Joanna C., Your Community. New York: Russell Sage Foundation, 1939.

Culbert, Jane F., The Visiting Teacher. New York: The Common Vealth Fund, 1929

Healy, William, Personaljty in Formation and Action. New York:

w. W. Norton and Company, 1938 .

Hock, Aroh 0., Administration of Pupil Personnel. Boston: Ginn and Company, 1929.

Johnston, J. Stoddard, Memorial History of Louisville from Its First Settlement to the Year 1896. New York: American Biographical Publishing Company, 1896 .

Kilpatrick, William Heard, A Reconstructed Theory of the Educative Process. New York: Bureau of Publications, Teachers College, Colunbia University, 1935.

Lowry, Fern, Readings in Social Case Work, 1920-1938. New York: Columbia University Press, 1939.

Nudd, Howard H., The Purpose and Scope of Visiting Teacher Work. New York: The Commonwealth Fund, 1930 . 
Gavin, Buth \%., Gray, A.A., Groves, Ernest R., Our Changing Social Order. New York: D.C. Heath and Company, $\overline{1939}$.

Plant, James S., Personality and the Cultural Pattern. New York: The Commonwealth Fund, 1939 .

Reavis, George H., Factors Controlling Attendance in Rural Schools. New York: Bureau of Publications Teachers College, Columbia University, 1920.

Robinson, Virginia, A Changing Psychology in Social Case Vork. Chapel Hill, University of North Carolina Press, 1930.

Bogers, Carl R., The Clinical Treatment of the Problem Child. New York: Houghton Kiffin Company, I939.

Shaw, Clifford, R., Delinquency Areas. Ghicago: University of Chicago Press, 1929.

Strang, Ruth, The Role of the Teacher in Personnel Vork. New York: Bureau of Fublications Teachers College, Columbia University, 1.932.

White House Conference on Child Health and Protection, 1930. Century Company, New York.

Wickham, E. K., Children's Behavior and Teachers' Attitudes. Commonvealth Fund, Division of Publications, $19 \overline{29}$

Torld Almanac and Bool of Facts. New York: Torld Telogram, 1914. 


\section{B. RECORDS, PAMPHLETS, PERIODICALS, NEUSPAPERS}

Acts of the General Assembly. Commonwealth of Kentucky. 1896, 1899,

Age-Grade Distribution, March, 1939, Grade-Progress Study, March, 1939. Files, Bureau of Research, $\overline{B o a r} d \overline{o f}$ Education Building, Louisville, Kentuc 'y.

A Study of Juvenile Delinquency in Louisville, 1935, W.P.A. Project.

Attendance Records, School Year, 1938-1939, Files Attendance Department, Board of Education Buil ling, Louis Tille, Kentucly.

Beyer, Clara, M•, Children of Wor ing Nothers in Philadelphia. Govermment Document, United States Department of Labor, Kashington, 1931.

Duties of the School Nurse, September, 1938. Files, City Health Department, City Hall.

Minutes of the Board of Education, Louisville Public School System, July 6,$1853 ;$ June 5,$1854 ;$ July 6, 1867; July 9, 1893. Office of the Secretary, Board of Education Building, Louisville, Kentucky.

National Youth Administration for Kentucky, Directory of Social Agencjes. Compiled in Cooperation with the Council of Social Agencies, Louisville, Kentucly, 1938 ,

Real Property Survey and Low Income Housing Area Survey of Louisville, Kentucky, 1938-1939. W.P.A. Project Pamphlet, W.P.A. Headquarters.

Record of School District Lines, September, 1938. Files Superintendent's Office, Lou is ville Board of Education Building, Louisvilie, Kentucky.

Registration of Families Known to Social Agencies, March, 1939. Card Catalogue Social Service Exchange, Louisville, Kentucky•

Review of Educational Research. American Educational Research Association, Washington, D.C., April, 1939.

Study of the Number of Foreign Children Attending the George W. Morris School, october, 1920. Florence Kahlert, Files, George \%orris School, Lovistile, Kentucky. 
The Louisville Post, September 25, 1922.

The Louisville Courier-Journal, July 31, 1938 ; February 13, 1939.

The Louisville Times, May 4, 1938. 
PERSONS INTERVIEWED

Frances Ingram, a former head resident of the Neighborhood House.

Edna Moss, Executive Secretary of the Young Women's Christian Association, 1939.

Harry Russman, a resident of the George W. Morris School District.

Charles Scholtz, President, Joe Denunzio Fruit Market, Louisville, Kentucky.

Mary Shaheen, a resident of the Worris School District.

Johanna Wehmhoff, a resident of the Goorge W. Morris School District. 